\author{
Universidade de São Paulo \\ Faculdade de Filosofia, Letras e Ciências Humanas \\ Departamento de Sociologia \\ Programa de Pós-graduação em Sociologia
}

\title{
Sobre a dominação e a emancipação na teoria crítica de Herbert Marcuse
}

Stefan Fornos Klein

Dissertação apresentada ao Programa de Pósgraduação em Sociologia, do Departamento de Sociologia da Faculdade de Filosofia, Letras e Ciências Humanas da Universidade de São Paulo, como requisito parcial para a obtenção do título de mestre.

Orientadora: Prof ${ }^{a}$. Dr ${ }^{a}$. Sylvia Gemignani Garcia

São Paulo

2006 


\author{
Universidade de São Paulo \\ Faculdade de Filosofia, Letras e Ciências Humanas \\ Departamento de Sociologia \\ Programa de Pós-graduação em Sociologia
}

\title{
Sobre a dominação e a emancipação na teoria crítica de Herbert Marcuse
}

Stefan Fornos Klein

Orientadora: Prof ${ }^{a}$. Dra . Sylvia Gemignani Garcia

São Paulo

2006 
Aos meus pais, Beth e Heinz, pelo carinho, pelas broncas, pelo afeto e especialmente pela compreensão e apoio que deles recebi durante todos esses anos. 


\section{Agradecimentos}

Sei que é injusto, mas devo ter esquecido de mencionar algumas das pessoas que muito me ajudaram durante a fase do mestrado (e anteriormente). Sem que a ordem a seguir expresse qualquer forma de importância, quero deixar registrados meus agradecimentos:

à Cláudia, que, entre idas e vindas, e apesar de tudo, sempre me apoiou enormemente;

aos meus amigos carnavalescos que já me agüentam há tanto tempo: Lucas, Rodolfo, Giovane, Talita, Joyce, Julia, Sandra, Thiago, Kadu e Lara;

aos meus irmãos, Karen e Christian;

à Renata, Tata, Bruno, Luciana, Gui (68), Adriana, Alê, Dani e Lia, pela amizade; aos colegas de graduação Danilo, Felipe e Leandro;

às e aos colegas do basquete, do grupo de pesquisa, do mestrado e da Plural;

à minha orientadora, Sylvia, pela paciência, dedicação e extraordinária perseverança que teve para comigo durante esses agora mais de três anos em que estamos trabalhando juntos, 30 meses no mestrado;

à Isabel Loureiro, pela imensa colaboração no acesso aos textos de Herbert Marcuse, assim como na condição de "orientadora informal", que me proporcionou um formidável diálogo intelectual acerca da teoria crítica;

à Olgária Matos, pela leitura atenta e pelos valiosos comentários feitos no exame de qualificação;

à Maria Helena Oliva Augusto, cujo apoio e suporte foram decisivos para a elaboração do projeto deste trabalho;

aos professores que, alguns desde a graduação e todos durante o mestrado, proporcionaram-me imensa ajuda: Irene Cardoso, Leopoldo Waizbort, Marcos Barbosa de Oliveira, Ricardo Musse, Elie Ghanem, Pablo Mariconda, Maria Aparecida Corrêa-Paty e Alvaro Comin.

a Jochen Stollberg, do Arquivo Herbert Marcuse, pela ajuda com a pesquisa documental, e a Peter Marcuse, pela autorização em citar os excertos inéditos do arquivo;

ao CNPQ, pela bolsa de estudos que facilitou enormemente a elaboração dessa pesquisa, e à CAPES, pelos auxílios concedidos para a participação em congressos. 
Resumo: Esta dissertação apresenta quatro textos de Herbert Marcuse, inéditos na língua portuguesa. Para introduzi-los, desenvolvo uma exposição acerca do modo como o autor, em sua teoria crítica da sociedade, aborda as questões da dominação e da emancipação.

Em uma breve introdução ao percurso intelectual de Marcuse, aponto as principais questões a permear o seu pensamento, com destaque para sua postura crítica face ao debate do marxismo como teoria social e como prática política, presente em toda a sua obra.

No item seguinte, exponho a análise dos principais sentidos sociais e culturais que caracterizam o avanço da racionalidade e da civilização tecnológicas, fundamentais para compreender o diagnóstico de Marcuse sobre a lógica da dominação no capitalismo organizado.

Em seguida, contextualizo, sucintamente, a institucionalização do ensino e da pesquisa acadêmicas nos Estados Unidos e os processos correlatos de especialização das disciplinas científicas e de profissionalização do trabalho intelectual.

Por fim, trato da questão dos sujeitos da emancipação, na interpretação de Marcuse, face à prática política dos movimentos contraculturais que emergiram durante os anos 1960 , indicando algumas tensões presentes em suas posições e enfatizando a importância da teoria para a transformação social, que se expressa em seu conceito de educação "política" ou "crítica".

Após essa exposição segue, em ordem cronológica, a tradução dos textos de Marcuse: uma entrevista ao periódico Pardon, realizada em 1968; uma entrevista ao semanário Der Spiegel, de 1969; uma conversa acadêmica com Hans Magnus Enzensberger, de 1970; e uma palestra, realizada em Frankfurt, em 1979. Os textos abordam, centralmente, duas questões candentes do debate da esquerda da época: as possibilidades da revolta contra a civilização tecnológica e de sua transformação radical.

Palavras-chave: Herbert Marcuse; racionalidade capitalista; emancipação; marxismo; educação. 
Abstract: This dissertation presents four texts by Herbert Marcuse, not yet translated into the portuguese language. To introduce them, I develop an exposition concerning the way in which the author, in his critical theory of society, approaches the questions of domination and emancipation.

In a brief introduction to Marcuse's intellectual course of life, I point out the central questions which permeate his thinking, punctuating his critical stand in face of the debate of Marxism as social theory and as political practice, present throughout his whole work.

In the next item, I expose the analysis of the main social and cultural meanings which characterize the advancement of technological rationality and civilization, fundamental to understand Marcuse's diagnosis about the domination logic of organized capitalism.

Afterwards I contextualize, succinctly, the institutionalization of academic teaching and research in the United States and the correlative processes of specialization of scientific disciplines and professionalization of intellectual work.

At last, I deal with the question of the subjects of the emancipation, in Marcuse's interpretation, in face of the political practice of the countercultural movements which emerged during the 1960s, pointing out some existing tensions in his positions and emphasizing the importance of theory for social transformation, which his concept of "political" or "critical" education expresses.

After this exposition follows, in chronological order, the translation of Marcuse's texts: an interview to the magazine Pardon, which took place in 1968; an interview to the weekly Der Spiegel, of 1969; an academic conversation with Hans Magnus Enzensberger, of 1970; and a speech, given in Frankfurt, in 1979. The texts approach, centrally, two blazing questions of the leftist debate of the time: the possibilities of the revolt against the technological civilization and its radical transformation.

Key-words: Herbert Marcuse; capitalist rationality; emancipation; Marxism; education. 


$\begin{array}{ll}\text { pas à pas } & \text { [passo a passo } \\ \text { nulle part } & \text { em nenhum lugar } \\ \text { nul seul } & \text { ninguém só } \\ \text { ne sait comment } & \text { não sabe como } \\ \text { petits pas } & \text { pequenos passos } \\ \text { nulle part } & \text { em nenhum lugar } \\ \text { obstinément } & \text { obstinadamente] }\end{array}$

Samuel Beckett

Poema por ocasião do $80^{\circ}$ aniversário de Herbert Marcuse

"A expressão social da pulsão de trabalho libertada é a cooperação, que, fundada sobre a solidariedade, orienta a organização do reino da necessidade e o desenvolvimento do reino da liberdade. Há uma resposta à pergunta que perturba os espíritos de tantos seres humanos de boa vontade: o que as pessoas devem fazer em uma sociedade livre? A resposta que, creio eu, acerta em cheio, vem de uma garota negra: 'Pela primeria vez em nossa vida seremos livre para pensar a respeito do que iremos fazer"”

\author{
Herbert Marcuse \\ Ensaio sobre a libertação
}




\section{Sumário}

I Sobre a dominação e a emancipação na teoria crítica de Herbert Marcuse ............. 2

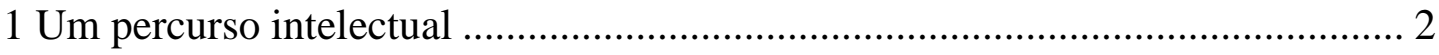

2 Capitalismo organizado e sociedade tecnológica: a dominação tecnocrática.... 23

2.1 Sociedade e tecnologia: a dominação 'racional' ........................................ 23

2.2 Ciência e tecnologia sob o pensamento unidimensional ............................. 28

3 A institucionalização da universidade moderna nos Estados Unidos ................ 42

4 Possibilidades teóricas e práticas da libertação: a contra-educação para a nova

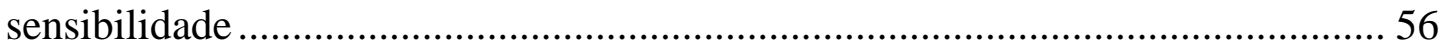

4.1 Os sujeitos da revolução: o marxismo entre a reforma e a revolução......... 56

4.2 Uma revolução com caráter: entre meios e fins ....................................... 76

5 Referências bibliográficas …...................................................................... 101

II Textos de Herbert Marcuse ................................................................................. 115

Quais as chances da revolução? ..............................Erro! Indicador não definido.

A revolução pela repulsa ........................................Erro! Indicador não definido.

EUA: a questão da organização e o sujeito revolucionário......Erro! Indicador não definido.

A revolta das pulsões de vida Erro! Indicador não definido. 


\section{Sobre a dominação e a emancipação na teoria crítica de Herbert Marcuse}

O leitor defrontar-se-á, nesse trabalho, com uma introdução crítica a um aspecto da obra do filósofo e teórico crítico Herbert Marcuse. O objetivo consiste em jogar luz sobre o modo de pensar uma teoria da emancipação social, o que Marcuse sustentou durante toda a sua vida, tanto no âmbito acadêmico quanto fora dele. Nesse sentido, seu principal objetivo foi o de apontar a importância da teoria marxista, com o fim explícito de demonstrar a relevância do reexame do materialismo histórico-dialético tendo em vista a interpretação da sociedade em seu tempo e, além disso, avançar na tarefa de apontar os problemas que se apresentaram com as mudanças estruturais ocorridas na sociedade capitalista desde o período em que Marx havia escrito. Nesse quadro, Marcuse apontou, permanentemente, a necessidade de provocar uma transformação radical da totalidade social.

\section{$1 \mathrm{Um}$ percurso intelectual}

Nascido em 19 de julho de $1898^{1}$, filho de uma família judaica relativamente abastada, Herbert Marcuse integrou o exército alemão aos 18 anos, mas não chegou a se envolver em combates. Com o término da Primeira Guerra Mundial, filiou-se ao SPD (Sozialdemokratische Partei Deutschlands; Partido Social-democrata Alemão), então o partido revolucionário, no qual permaneceu durante dois anos e que deixou em meio à onda de desesperança originada pelas suspeitas de o partido ter sido responsável pelos assassinatos de Karl Liebknecht e Rosa Luxemburg ocorridos em 15 de janeiro de $1919^{2}$. O trágico paradoxo entre o objetivo do partido de disseminar a perspectiva de esquerda e uma completa intolerância face à existência de opiniões divergentes entre os seus

\footnotetext{
${ }^{1}$ Para a pequena construção biográfica e intelectual que vem a seguir, fiz uso de KATZ, Barry, 1982 e KELLNER, Douglas, 1984; assim como de um sítio organizado e mantido por um dos netos de Herbert Marcuse (www.marcuse.org/herbert), onde constam diversas informações envolvendo sua vida pessoal 'privada' e obras. Outra biografia, por Morton Schoolman, não foi utilizada, tendo sido duramente criticada em duas resenhas pela falta de fundamentação documental de suas interpretações; cf. BOKINA, John, 1983 e KELLNER, Douglas, 1983.

${ }^{2}$ Ambos foram integrantes do SPD, deixando o partido em 1914 (Rosa) e 1916 (Liebknecht), após o que fundaram a Liga Espártaco (Spartkusbund) a qual, posteriormente, desembocaria no KPD (Kommunistische Partei Deutschlands - Partido Comunista Alemão). Rosa Luxemburg foi uma arguta crítica do modo de compreensão do marxismo e da instituição da prática, assim como da burocratização do movimento operário, sendo a sua modelagem de uma democracia efetiva, organizada sob a forma da república conselhista, uma referência importante para Marcuse como pode ser observado, entre outros, em MARCUSE, Herbert, 1999 [1947], p. 298.
} 
correligionários pode ter produzido um primeiro germe da desconfiança e rejeição de Marcuse da via da política institucional. Em uma entrevista ao final de sua vida, ele afirma: "Quem me educou? Em todo caso, não foi a escola, o Ginásio Real-Prussiano, e só até um certo grau, minha família. Meu pai era um homem muito autoritário, mas, como se diz, de bom coração. Isso não me fez mal. $O$ que realmente me educou foi a história como a vivi. Quer dizer, a Primeira Guerra Mundial - fui mobilizado em 1916 - e a fracassada revolução alemã de 1918/19. Na época eu estava em Berlim e essa foi realmente a primeira e a verdadeira educação que recebi. Em seguida, o que também ajudou muito foram os livros, os livros e os amigos e colegas no Instituto"3. A primeira experiência política da juventude parece, retrospectivamente, emblemática dos profundos desafios postos no começo do século para uma perspectiva emancipatória radical.

Em outra direção e seguindo o ponto de vista de Peter Gay, a Revolução, mesmo trazendo desesperança em diversas esferas da vida, teve efeitos positivos que parecem ser mais frutíferos no que tange a uma transformação da cultura alemã. "À luz dos acontecimentos, a Revolução e suas conseqüências obtiveram muitas realizações. Foi varrida para sempre a casa governante Prussiana e outras monarquias germânicas, poderosas ou pequenas. Ao menos, educou alguns alemães nos caminhos da política prática. Estabeleceu um Estado democrático. Deu novas oportunidades a talentos inaceitáveis para promoções na época do Império, abriu centros de prestígio e poder para professores progressistas, teatrólogos modernos e pensadores políticos democráticos"4. Essa conjuntura parece ter sido um impulso decisivo para que Marcuse seguisse a carreira acadêmica, que iniciou com os estudos em germanística realizados na Universidade Humboldt de Berlim em 1919 e 1920, após o que foi para Friburgo em Breisgau estudar filosofia e economia política, onde acabou realizando a sua Promotion (doutoramento), em 1922, acerca do romance moderno na literatura alemã, sob o título de Der Deutsche Künstlerroman, $O$ romance de artista alemão. Marcuse analisa um conjunto de obras de Goethe, Schlegel, Novalis e Thomas Mann, entre outros, explorando as relações entre o autor e seus personagens, com o que aborda essencialmente a questão das possibilidades da constituição de uma subjetividade autônoma no contexto moderno, tal como se expressa no romance realista e no romântico. O tema do estranhamento e da transcendência em relação ao mundo e, assim, o da arte como perspectiva para a emancipação face à ordem social vigente será retomado pontualmente por Marcuse em diversos trabalhos, e voltará com mais

\footnotetext{
${ }^{3}$ MARCUSE, Herbert, 1999 [1978], p. 11.

${ }^{4}$ GAY, Peter, 1978 [1968], p. 31.
} 
força em seus últimos livros Contra-revolução e revolta (1972) e A dimensão estética (1977).

Ainda em 1922, Marcuse retornou a Berlim, onde trabalhou numa editora de livros e manteve seus estudos literários, sem integrar nenhum partido (o principal partido de oposição então era o KPD, Kommunistische Partei Deutschlands; Partido Comunista Alemão). Em 1924, casou-se com Sophie Wertheim, uma estudante de matemática e estatística, com a qual teve o seu único filho, Peter, nascido em 1928. Sob o impacto da publicação de Ser e tempo (1927) de Martin Heidegger, voltou para Friburgo com o intuito de estudar filosofia e obter a orientação de Heidegger para sua Habilitation ${ }^{5}$, com o trabalho A ontologia de Hegel, o que acabou não se concretizando. Não há consenso entre os intérpretes em torno da razão que levou Heidegger a recusar o trabalho ${ }^{6}$. O trabalho foi publicado em 1928, mas não representou a aquisição de um grau acadêmico.

Recordando esse período, ao final da vida, Marcuse aponta para o contexto histórico que colocou toda uma geração face à busca de novos caminhos. O impacto da derrota da revolução alemã, já importante para a sua 'educação', manteve-se, sendo agora expandido ao colocar um problema muito mais amplo, relativo à possibilidade da unidade entre a teoria e a prática, tão característica da teoria social marxista. Nesse contexto, é que a perspectiva do pensamento fenomenológico heideggeriano afigurou-se como uma alternativa possível, sinalizando a orientação do que era então compreendido como "uma filosofia realmente concreta" ${ }^{\text {. }}$.

Marcuse jamais obteve a Habilitation. Após 1932, abandona completamente a idéia, já que não havia sentido em alcançar essa qualificação na Alemanha, tendo em vista a expansão do domínio nazista e o fechamento da estrutura acadêmica para os judeus ${ }^{8}$.

Segundo Kellner, o principal sentido do impacto que a filosofia heideggeriana teve sobre os escritos marcuseanos refere-se à concretude que ele encontrou nessa corrente fenomenológica. Isso significa dizer que nela havia, em relação aos estudos de Marx

\footnotetext{
${ }^{5}$ A Habilitation ascende o titulado à condição de Privatdozent, ou seja, possibilita que possa iniciar a carreira docente junto a alguma universidade.

${ }^{6}$ Cf. KATZ, Barry, 1982; KELLNER, Douglas, 1984 e JANSEN, Peter-Erwin, 1999.

${ }^{7}$ Cf. LOUREIRO, Isabel Maria, 1998, p. 101 e MARCUSE, Herbert, 1980 [1977], pp. 12 e 13.

${ }^{8}$ Em sua análise da comunidade acadêmica alemã de 1890 a 1933, Fritz Ringer aponta a ambigüidade entre a dependência do pensamento alemão com relação a uma série de intelectuais judeus ou de origem judaica, como Karl Marx, Georg Simmel e Karl Mannheim, e a sua rejeição por parte do sistema de ensino, pautado pelas questões religiosas do governo pré-Weimar. Cf. RINGER, Fritz K., 2000 [1968], pp. 135-138 e 225-227. É de certa forma curioso que, nessa análise sociológica da instituição universitária e de seus mentores naquele período, o autor não tematize nem o marxismo, nem o Instituto de Pesquisa Social. O caso do Instituto é mais compreensível, dado o período que sua pesquisa abarca, quando ainda não havia projeção dos autores que viriam a compor a assim chamada Escola de Frankfurt. Já quanto ao marxismo, a sua influência era sentida, ao menos no debate intelectual, em referências textuais de Weber e Mannheim e não deveria, portanto, ser ignorada em tal grau.
} 
empreendidos até então, uma aproximação maior com a realidade concreta, traduzida no conceito de historicidade 9 . A relação de determinação entre infra e superestrutura que fundamentava o pensamento marxiano parecia tratar sempre de entidades coletivas em alguma medida despojadas de toda dimensão individual, largamente dependentes de sua posição na estrutura produtiva. Por mais que considerasse essa relação importante, Marcuse demonstrava, ao mesmo tempo, que via nela uma certa insuficiência, que, naquele momento, parecia poder ser completada pela fenomenologia.

Os seus estudos de Marx intensificaram-se, especialmente na medida em que foram sendo publicados mais manuscritos inéditos. Essa série culminou com os Manuscritos econômico-filosóficos, publicado em 1932, e a respeito do qual ele escreveu uma das primeiras resenhas ${ }^{10}$, em que aponta para o vigor teórico do texto, no qual identifica as "novas fontes" do materialismo histórico. Afirma Marcuse que, em 1932, "demo-nos conta, pouco a pouco - e falo no plural pois realmente não foi apenas um processo individual - de que essa concretude [da filosofia de Heidegger] era bastante errônea. [...] Durante todo esse tempo, eu já havia lido Marx e continuei lendo Marx. Então veio a publicação dos Manuscritos econômico-filosóficos. Aquele foi, provavelmente, o marco. Neles havia, em certo sentido, um novo Marx que era realmente concreto e que, ao mesmo tempo, ia além do petrificado marxismo prático e teórico dos partidos" ${ }^{11}$. Em sua resenha dos Manuscritos, ele escreve "que na situação fática do capitalismo não se trata somente de uma crise econômica ou política, mas sim de uma catástrofe da natureza humana - esse reconhecimento condena de antemão ao fracasso qualquer reforma meramente econômica ou política, demandando necessariamente a superação [Aufhebung] catastrófica do estado de coisas factual mediante a revolução total"12.

A inserção de Marcuse no marxismo ocidental ${ }^{13}$ pautou-se também pelas interpretações de Georg Lukács e Karl Korsch ${ }^{14}$. Em Lukács, as contribuições principais são: construir o conceito de reificação, desenvolvido a partir do fetichismo da mercadoria de Marx, expondo a sua expansão pelos mais variados âmbitos da vida material e simbólica,

9 Cf. KELLNER, Douglas, 1984, pp. 38-68. Para uma análise da aproximação entre a filosofia heideggeriana e a teoria social marcuseana ver OLIVEIRA, Robespierre de, 2001, em especial pp. 13-35.

${ }^{10}$ Cf. MARCUSE, Herbert, 2004 [1932].

${ }^{11}$ MARCUSE, Herbert, 1980 [1977], p. 13.

${ }^{12}$ MARCUSE, Herbert, 2004 [1932], p. 536 - grifos no original.

13 Para o "marxismo ocidental", cf. ANDERSON, Perry, 2003 [1976] e THERBORN, Göran, 1995, pp. 248-255. Para uma crítica à interpretação de Lukács feita por Anderson ver MUSSE, Ricardo, 1998, em especial p. 21, nota 10.

${ }^{14}$ Cf. LUKÁCS, Georg, 2003 [1923b] e KORSCH, Karl, 1977 [1923]. A 'dívida' da teoria crítica da Escola de Frankfurt para com Lukács e Korsch, ocorrida no bojo da ascensão e dissolução da revolução na Alemanha do começo do século XX, e que é tanto teórica quanto histórica, é abordada em MATOS, Olgária Chain Féres, 1989, pp. 231-245. 
estendendo-se para a esfera cultural como conseqüência da especialização e divisão exacerbada do trabalho, que impossibilita os seres humanos de adquirir a visão da totalidade (o que demonstra na teoria do direito e da ciência econômica, além de retratar o jornalista como um exemplo do embotamento espiritual). Além disso, Lukács, ao discutir criticamente o marxismo vigente, define como o marxismo ortodoxo, ou seja, radical, aquele caracterizado pelo método do materialismo histórico-dialético ${ }^{15}$. Argumenta ele, portanto, que seria a negação da própria teoria de Marx abstrair o contexto histórico da análise. As mudanças qualitativas na estrutura social capitalista exigiam o exame crítico da validade da teoria, mas não do método.

A filiação de Marcuse à concepção do marxismo como um método, tal como elaborado por Lukács, é visível na maior parte dos textos que abordam o tema, apesar de raramente citá-lo, seja para refutar os ataques dos marxistas dogmáticos, seja para empreender a defesa da lucidez dessa abordagem. Essa perspectiva de sua teorização é reconhecida pelo próprio autor, como, por exemplo, nessa passagem, de 1957: "Com algumas exceções notáveis (como a de História e consciência de classe de Georg Lukács e os mais recentes reexames franceses do marxismo), o materialismo dialético foi minimizado como um perturbador 'resíduo metafísico' na teoria marxista, ou formalizado num método técnico, ou esquematizado numa Weltanschauung [visão de mundo]"16.

Essa perspectiva também é abordada por Korsch, cuja argumentação leva às últimas conseqüências a implementação da unidade de teoria e prática assim como as implicações da filosofia sobre o marxismo e vice-versa. Acima de tudo, Korsch destaca a necessidade imperiosa e, em sua visão, muito mal-fundamentada até então, da 'aplicação' da teoria da história dialético-materialista aos contextos e às condições objetivas pós 1880. Para ele, as três linhagens marxistas que detiveram a supremacia no início do século XX (Renner, Kautsky e Lenin) não foram capazes de cumprir tal tarefa. De forma geral, para ele, “muitos intérpretes burgueses de Marx e igualmente muitos marxistas julgaram subseqüentemente poder estabelecer uma distinção entre as matérias históricas e as de teoria econômica na obra principal de Marx, O capital; tanto bastou para provar que eles não compreenderam ainda absolutamente nada do verdadeiro método utilizado por Marx na crítica da economia política, já que uma das características essenciais do método materialista dialético é que para ele esta distinção não existe: ele consiste essencialmente, pelo contrário, na compreensão teórica da história. Da mesma forma, a ligação indissolúvel

\footnotetext{
${ }^{15}$ Cf. LUKÁCS, Georg, 2003 [1919] e 2003 [1921].

${ }^{16}$ MARCUSE, Herbert, s.d. [1957], p. 2 - aspas e grifos no original. Para outras referências explícitas a Lukács ou Korsch cf. MARCUSE, Herbert, 2004 [1930a]; 2004 [1930b] e 2004 [1931].
} 
entre teoria e prática que constitui a característica mais significativa da primeira forma comunista do materialismo marxista não desaparece de maneira nenhuma na forma posterior do sistema" ${ }^{" 17}$. O assim denominado marxismo crítico, que seria um elemento constituinte da teoria social crítica elaborada no trabalho do Instituto, deriva em boa parte dos diagnósticos desses dois autores. É importante notar a convergência da argumentação de Lukács e de Korsch. Escrevendo simultaneamente, estabeleceram uma primeira dimensão da crise do marxismo, realçando a necessidade de aplicar o materialismo histórico à própria análise dialética da sociedade estabelecida por Marx. Em Lukács, a ênfase recai sobre a prática política e a questão da organização da oposição; em Korsch, sobre a crítica filosófica e a organização das correntes de pensamento; ambas as diretrizes serão objetos da consideração de Marcuse.

A aproximação com o Instituto de Pesquisa Social deu-se ao final de 1932. No ano seguinte, em que Hitler ganha as eleições, o Instituto emigra da Alemanha para Genebra, na Suíça, e Marcuse acompanha-o, já que "estava muito claro, em finais de 1932, que sob o regime nazista eu jamais poderia obter uma cátedra" ${ }^{\prime 18}$. O Instituto de Pesquisa Social foi fundado em 1924, sob a direção de Carl Grünberg, graças ao financiamento oferecido por Hermann Weil ao seu único filho Felix Weil ${ }^{19}$. Herdeiro de uma fortuna razoável, ele pôde colocar em prática o plano de fundar uma instituição autônoma, capaz de desenvolver os seus trabalhos com independência intelectual, tanto em relação ao sistema de ensino nacional quanto aos partidos políticos.

Peter Gay destaca a orientação marxista do Instituto de Pesquisa Social quando da época de sua criação. Tanto que se aventou denominá-lo "Instituto de Marxismo", o que, entretanto, nunca ocorreu. Com a passagem da direção para Max Horkheimer, em 1931 ${ }^{20}$, essa orientação foi matizada, aprofundando o distanciamento intelectual em relação ao marxismo dogmático e ao convencionalismo acadêmico, considerando-se que a "espécie de ciência radical que pretendiam praticar encontrava pouca aceitação na hierarquia

\footnotetext{
${ }^{17}$ KORSCH, Karl, 1977 [1923], p. 93. Nesse contexto, expressa-se a idéia de que "renegando tanto a abstração filosófica da teoria pura quanto a abstração oposta, antifilosófica, da prática pura, Korsch nomeia, portanto, como crítica apenas a unidade, modelada segundo o conceito de práxis, entre a teoria e a prática". MUSSE, Ricardo, 1998, p. 24. Marcuse afirma: “A teoria marxista é uma interpretação da história e define, na base dessa interpretação, a ação política que, utilizando as possibilidades históricas dadas, pode estabelecer uma sociedade sem exploração, miséria e injustiça. Assim, tanto na sua estrutura conceitual quanto na sua prática política, a teoria marxista pode 'responder' à realidade histórica em processo: a modificação dos conceitos teóricos e da prática política a ser guiada por eles é parte da própria teoria". MARCUSE, Herbert, s.d. [1957], p. 1. Cf., ainda, MARCUSE, Herbert, 1998 [1969b] e 2004 [1970].

${ }_{18}^{18}$ MARCUSE, Herbert, 1980 [1977], p. 15.

${ }^{19}$ Cf. JAY, Martin, 1991 [1973], pp. 21-24.

${ }^{20}$ Cf. GAY, Peter, 1978 [1968], pp. 53-55.
} 
acadêmica estabelecida. [...] Perante essa situação, a idéia de Weil de um instituto de pesquisa social autofinanciado parecia uma excelente oportunidade de distanciar-se dos canais comuns da vida universitária"21.

Sob a ameaça da política anti-semita, que se generalizava na Europa, ocorre uma nova transferência em 1934 e o Instituto instala-se na Universidade de Columbia em Nova Iorque, nos Estados Unidos da América. Marcuse desembarca na cidade em 04 de julho de 1934.

Nesse período inicial, Marcuse contribui intensamente com o Instituto ${ }^{22}$. Ele era um dos principais resenhistas da Revista de Pesquisa Social (Zeitschrift für Sozialforschung), nome dado por Horkheimer à publicação do Instituto, que deixará de ser editada em 1941. Ele também escreveu alguns artigos explorando tanto a concepção de teoria crítica a guiar o seu trabalho teórico e o de seus colegas ${ }^{23}$, quanto dando início a uma das principais marcas de sua teoria social: a crítica da ideologia e da cultura ${ }^{24}$. Nesse sentido, sua teorização passa pelo debate com o pensamento de diversas correntes filosóficas, assim como recorre constantemente à análise empírica na exposição de seus argumentos. Mesmo cedendo à necessidade, presente na "cuidadosa redação dos textos" 25 , de matizar a linguagem dos escritos em função do sentimento anticomunista presente nos Estados Unidos, Marcuse preservou as suas raízes materialistas. A utilização de 'teoria crítica' ao invés de 'marxismo'; 'emancipação' ao invés de 'revolução' e 'democracia' no lugar de 'socialismo' não enfraqueceram o radicalismo de seu conjunto de idéias. Questionado, na década de 1970, sobre os principais estímulos encontrados no Instituto, Marcuse afirma: "Primeiro: $o$ debate consideravelmente independente acerca do marxismo, da teoria marxiana. Segundo: a excelente análise da situação política. Por exemplo, ninguém duvidava, no Instituto, de que Hitler chegaría ao poder e que, uma vez que houvesse chegado ao poder, permaneceria nele durante um período de tempo imprevisível. E terceiro: a psicanálise. Antes, já havia lido Freud, mas minha ocupação sistemática com Freud somente ocorreu no Instituto"26.

\footnotetext{
${ }^{21}$ JAY, Martin, 1991 [1973], p. 25.

${ }^{22}$ Para uma crítica tosca da obra de Marcuse ver MACINTYRE, 1973 [1970]. O seu livro demonstra uma ampla falta de compreensão no que se refere a três pontos importantes: a base teórica de Marx propriamente dita; o conteúdo crítico da obra marcuseana; e a relação entre a teoria crítica e a teoria marxista. Uma série de suas afirmações deixa patente que ele não leu por inteiro diversas das obras e, especialmente, desconsiderou boa parte das notas de rodapé de Marcuse, além de desconhecer uma série de detalhes biográficos. Para mais referências ver KELLNER, Douglas, 1984, p. 421, nota 24.

${ }^{23}$ Cf. MARCUSE, Herbert, 2004 [1937a].

${ }^{24}$ Cf. MARCUSE, Herbert, 2004 [1936]; 2004 [1937b]; 2004 [1938] e 1980 [1941].

${ }^{25}$ Cf. JAY, Martin, 1991 [1973], p. 66.

${ }^{26}$ Cf. MARCUSE, Herbert, 1980 [1977], p. 16.
} 
Em 1941, vem a público a primeira das 'grandes obras' de Marcuse, Razão $e$ revolução $o^{27}$. Nela, ele interpreta uma das bases filosóficas do pensamento marxiano, ao reconstruir a apropriação crítica da teoria social dialética hegeliana por parte de Marx, com o seu ponto de vista envolvendo a estruturação desse pensamento partindo das bases relativamente ortodoxas do jovem Marx. Esse livro significa, portanto, a sistematização da visão de Marcuse a respeito do surgimento do método de Marx. Publicado originalmente em inglês, como a maior parte de seus escritos, Razão e revolução representa "na realidade, a introdução da teoria crítica ao mundo de língua inglesa - Razão e revolução, um livro que muitos consideram uma das melhores obras de Marcuse e que viria a introduzir Hegel, Marx e a teoria social crítica para muitos no mundo de língua inglesa, incluindo a mim" ${ }^{28}$.

Nessa obra, Marx é identificado como o único a desenvolver os fundamentos críticos da filosofia de $\mathrm{Hegel}^{29}$, produzindo a passagem da filosofia para a teoria social. Por isso Marcuse refaz a ordem cronológica que dá aos precursores da sociologia institucionalizada, Auguste Comte e Leopold von Wiese, a primazia na história da teoria social. Isso não significa, de forma alguma, dizer que Marx seja o pai da sociologia positivista praticada na disciplina institucionalizada. Ele inaugura, isso sim, uma forma de abordagem não mais dirigida pela filosofia e que, assim, ganhou a denominação de teoria social. Enquanto a sociologia, de modo a questionar o idealismo filosófico, incorpora os métodos das ciências naturais, Marx escapa a esse dualismo por meio de sua teoria social crítica (dialética), que não se conforma a uma essência metafísica do ser humano mas também não procura por leis imutáveis que determinem o comportamento humano. É para essa direção que aponta, portanto, o diagnóstico que Marcuse efetua quanto às conseqüências da doutrina da racionalidade moderna na experiência do mundo: "Os homens acreditavam que as suas interrelações resultavam de leis objetivas que operam com a força das leis físicas, e que a sua liberdade consiste em adaptar a sua existência privada a essa força. Em virtude disso, um notável ceticismo conformista acompanha o desenvolvimento do racionalismo moderno. Quanto mais a razão triunfou na tecnologia e na ciência natural, tanto mais relutantemente ela clamou por liberdade na vida social humana” ${ }^{\natural 0}$. Expressa-se, nessa passagem, a junção da crítica da história da filosofia com a da regressão representada pela reificação da racionalidade científica produzida pela sociedade capitalista.

\footnotetext{
${ }^{27}$ Cf. MARCUSE, Herbert, 1999 [1941].

${ }^{28}$ KELLNER, Douglas, 1984, p. 129 - grifo no original.

${ }^{29}$ MARCUSE, Herbert, 1999 [1941], p. 252.

${ }^{30}$ MARCUSE, Herbert, 1999 [1941], p. 256.
} 
Em Razão e revolução, Marcuse procura pôr a descoberto tanto a relevância de Hegel para o percurso da filosofia como um todo quanto esclarecer a forma peculiar de apropriação que Marx faz de Hegel. O principal ponto nesse sentido consiste em que "para Hegel a totalidade era a totalidade da razão, um sistema ontológico fechado, em última instância idêntico ao sistema racional da história. O processo dialético de Hegel era, assim, um processo ontológico universal, no qual a história era modelada [patterned] pelo processo metafísico do ser. Marx, por outro lado, separou a dialética dessa base ontológica. Em seu mundo, a negatividade da realidade torna-se uma condição histórica, associada a uma forma histórica particular de sociedade. A totalidade a qual a dialética marxiana chega é a totalidade da sociedade de classes, e a negatividade que está subjacente às suas contradições e que molda todo o seu conteúdo é a negatividade das relações de classe. A totalidade dialética, novamente, inclui a natureza, mas somente na medida em que a última adentra e condiciona o processo histórico de reprodução social" ${ }^{31}$. É apenas por meio da abordagem histórica, materialista, que a dialética é capaz de apreender o desenvolvimento das condições objetivas e subjetivas da situação concreta existente e efetuar uma análise da sociedade tal qual ela se põe. Sem o abandono dos pressupostos ontológicos, permanece-se no campo da ideologia.

Outro traço fundamental da apropriação marcuseana de Marx refere-se à perspectiva da transformação social para a realização histórica da emancipação do homem como diretriz do trabalho do pensamento. Tomando distância da perspectiva positiva (positivista) que afirma a neutralidade de uma teoria social 'científica' que se limita a descrever aquilo que é e a investigar as relações de causalidade que lhe são subjacentes, a perspectiva marxiana parte explicitamente de uma orientação de valor, qual seja, o da emancipação do ser humano e da realização histórica da liberdade. Para Marcuse, "as relações fundamentais das categorias marxianas não se encontram ao alcance da sociologia ou de qualquer ciência que esteja preocupada em descrever e organizar os fenômenos objetivos da sociedade. Elas aparecerão como fatos somente para uma teoria que as aborde na antevisão [preview] de sua negação. De acordo com Marx, a teoria correta é a consciência de uma prática que visa a transformação do mundo"32.

\footnotetext{
${ }^{31}$ MARCUSE, Herbert, 1999 [1941], p. 314 - grifo no original. Anteriormente é estabelecida uma primeira virada metodológico-teórica que baliza as conclusões posteriores a respeito da passagem da filosofia à teoria social: "todos os conceitos filosóficos da teoria marxiana são categorias econômicas e sociais, enquanto as categorias sociais e econômicas de Hegel são todas conceitos filosóficos. Até mesmo os primeiros escritos de Marx não são filosóficos. Eles expressam a negação da filosofia, apesar de ainda o fazerem numa linguagem filosófica". Id., ibid., p. 258.

${ }^{32}$ MARCUSE, Herbert, 1999 [1941], p. 321 - grifo no original.
} 
O ano de 1942 marca o estabelecimento de Marcuse em Washington. Naquele momento, o Instituto passava por sérias dificuldades financeiras, de modo que não mais era possível garantir a todos os seus membros o sustento necessário ${ }^{33}$. A ajuda oferecida a diversos migrantes judeus refugiados, assim como o próprio financiamento da sobrevivência material das pessoas e da pesquisa, fez minguar os fundos disponíveis. Em virtude disso, diversos integrantes emigrados foram obrigados a procurar outras formas de sustento. Adorno passou a integrar um projeto de pesquisa coordenado por Paul Lazarsfeld, enquanto Franz Neumann, Otto Kirchheimer e Marcuse trabalharam em divisões do governo norte-americano, este primeiramente na Divisão de Informações de Guerra (Office of War Information) e depois na Divisão de Serviços Estratégicos (Office of Strategic Services). O objetivo dessa divisão governamental era ajudar a combater o regime totalitário na Alemanha, objetivo compartilhado por Marcuse, apesar das marcantes diferenças ideológicas em relação à maioria de seus colegas. O instrumento de combate era a contrapropaganda, sendo em virtude disso necessário compreender a mentalidade alemã nacional-socialista, entender como era disseminada a ideologia e assim estruturar os mecanismos para enfrentar tal situação ${ }^{34}$. Com esse propósito, em 1946 e 1947, Marcuse esteve alguns meses na Alemanha, realizando trabalhos de campo para ajudar no projeto de desnazificação. Na volta aos EUA, com a extinção do $O S S$, passou a integrar o Departamento de Estado estadunidense, trabalhando em Washington.

A manutenção da sua estada na capital deveu-se exclusivamente ao câncer que acometia a sua esposa Sophie, impossibilitando-os de pensar em mudança. Portanto, é necessário considerar que "em abril de 1948 ele havia sido nomeado chefe do setor centroeuropeu [Central European Branch] da divisão do departamento responsável pela pesquisa da Europa. Ele havia, entretanto, tornado-se intelectual e politicamente isolado: com as partidas de Neumann, Schorske, Hughes e muitos outros, ele encontrou-se cada vez mais cercado de indivíduos cujas percepções políticas estavam estreitamente fixadas sobre 'a ameaça comunista à Europa' e cujo conceito de trabalho intelectual implicava a projeção de possibilidades muito mais cibernéticas do que dialéticas" ${ }^{35}$.

No meio-tempo que se seguiu à volta de Horkheimer à Alemanha, ocorrida em 1950, foi articulada uma tentativa de levar Marcuse de volta. Sua correspondência da época

\footnotetext{
${ }^{33}$ Cf. JAY, Martin, 1991 [1973], pp. 203 e 204. Também as cartas trocadas entre Marcuse e Horkheimer nesse período fornecem indicações quanto às dificuldades para a organização do corpus de pesquisadores naquele período do Instituto. Cf. HORKHEIMER, Max e MARCUSE, Herbert, 1999 [1941-1949].

${ }^{34}$ Cf. MARCUSE, Herbert, 1999 [1942] e 1999 [1946/1947].

${ }^{35}$ KATZ, Barry, 1982, p. 134.
} 
com Horkheimer ${ }^{36}$ revela o quanto ele desejava retornar, e principalmente trabalhar em conjunto com Horkheimer. Mas este não é capaz de criar uma oportunidade para tal volta e, como se sabe, deu clara preferência a Adorno como parceiro de seus trabalhos.

Com o falecimento de Sophie, em 1951, Marcuse deixou o trabalho em Washington. O cenário do pós-guerra desloca o eixo das preocupações estadunidenses no contexto político para a guerra fria, o que leva Marcuse a direcionar a sua atenção para as semelhanças entre a União Soviética e os EUA, pondo algumas das bases para o aperfeiçoamento da crítica das formas de dominação tecnológica regidas por um aparato repressivo e que degeneram no que ele chama, naquele momento, de "bloco neofascista" e denominaria, futuramente, de "democracia totalitária" "37. Os quatro anos seguintes, entre Nova Iorque (Universidade de Columbia) e Cambridge (Universidade de Harvard), foram dedicados a lecionar e escrever. Marcuse trabalhou durante dois anos nos Institutos de Estudos e Pesquisa da Rússia em cada uma das universidades, estabelecendo o material teórico e empírico que serviu como base para um livro publicado somente em 1958, Marxismo soviético, estudo crítico do regime soviético, que ele considera pouco central em sua produção teórica ${ }^{38}$. Pode-se destacar nesse trabalho sua crítica à interpretação dogmática dos manuscritos de Marx, que acarreta muitas vezes uma interpretação anacrônica de sua teoria, destituindo-a de seu poder crítico. Reafirmando sua interpretação dialética, Marcuse sustenta que "faz parte da estrutura histórico-dialética da teoria de Marx que os seus conceitos se alterem com uma mudança nas relações de classe fundamentais que são seu objeto - mas de tal maneira que o novo conteúdo é dado de forma que os elementos imanentes ao conceito original são desdobrados, mantendo-se tanto a conseqüência teórica quanto a identidade desse conceito" 39 .

A total ausência desse movimento na leitura dogmática leva, no caso do sistema soviético, à degradação da teoria em ideologia, com graves consequiências práticas, que se manifestam em diversas dimensões da socialização, tal como, por exemplo, no estilo artístico 'oficial', o "realismo soviético". Na esfera da organização produtiva, notadamente, o desenvolvimento soviético avança em uma direção comprometedora. "O sistema soviético parece ser o exemplo de um retardatário que, após um longo período de prolongado atraso, 'pula' diversos degraus de desenvolvimento, junta-se a uma

\footnotetext{
${ }^{36}$ Cf. WIGGERSHAUS, Rolf, 1994 [1986], pp. 462-466; HORKHEIMER, Max e MARCUSE, Herbert, 1999 [1941-1949].

${ }^{37}$ Cf. MARCUSE, Herbert, 1999 [1947] e 2004 [1964a].

${ }^{38}$ Kellner discorda da irrelevância concedida ao texto por Marcuse. Cf. KELLNER, Douglas, 1984, pp. 198 e 200.

${ }^{39}$ MARCUSE, Herbert, 2004 [1958], p. 37.
} 
tendência geral da sociedade industrial tardia e ultrapassa-a copiosamente. Os degraus que foram pulados são os do absolutismo esclarecido e do liberalismo, da economia de livre concorrência com a sua cultura madura de classe média e com a sua ideologia individualista e humanitária. O esforço em passar, em tempo recorde, de um estado de atraso para alcançar o nível dos países da sociedade industrial avançada, levou à construção e ao uso de um aparelho de produção acachapante no interior de um sistema de dominação e regulamentação, que era incompatível com a racionalidade individual e com o liberalismo. Aqui localizam-se as raízes da luta incessante do marxismo soviético contra os elementos liberais e idealistas da 'ideologia burguesa'; a luta reflete a organização social das forças de produção, que são antes instrumentos de controle que de libertação" ${ }^{, 40}$. Assim, a doutrina stalinista, ao defender a necessidade da redução da jornada de trabalho, tinha em mente não a criação de tempo livre mas sim a formação e o treinamento técnico (Bildung e Ausbildung) dos indivíduos para a sua inserção na sociedade do marxismo soviético ${ }^{41}$. Desse modo, Marcuse revela as formas pelas quais o sistema soviético assemelha-se à sociedade industrial do capitalismo ocidental, partilhando com ela a profunda adesão à lógica da racionalidade tecnológica para o controle dos homens e da natureza.

Em 1955, Marcuse publica Eros e civilização, livro alinhado a um dos principais projetos da Escola de Frankfurt, que era o de articular os conhecimentos psicanalíticos à teoria marxiana, de forma a incorporar à análise a consideração das dimensões subjetivas da experiência contemporânea, uma necessidade posta pelo próprio desenvolvimento histórico dos mecanismos de repressão e de controle que passam a atuar no nível dos sentidos e das pulsões básicas da vida psíquica dos indivíduos.

Em Eros e civilização, Marcuse segue enfrentando a questão posta pelos acontecimentos históricos da primeira metade do século e que ocupava os intelectuais não conformistas do período, a questão da "servidão voluntária", da paradoxal degeneração do potencial transformador da ação humana em uma sociedade (industrial), na qual seria possível identificar a presença das condições objetivas da superação das relações de dominação. Face a esse dilema, Marcuse busca no pensamento psicanalítico de Freud a perspectiva e os instrumentos conceituais para a abordagem da questão das condições subjetivas da realização histórica da liberdade, revelando os modos como a cultura de massas do capitalismo organizado reproduz, na dimensão mesma da subjetividade, a

\footnotetext{
${ }^{40}$ MARCUSE, Herbert, 2004 [1958], pp. 90 e 91 - aspas no original.

${ }^{41}$ Cf. MARCUSE, Herbert, 2004 [1958], respectivamente pp. 127-135 e pp. 174 e 175.
} 
dinâmica das estruturas de dominação. Trata-se de identificar, no período contemporâneo, o "elemento de autoderrota" que parece estar presente ao longo dos tempos na dinâmica dos processos revolucionários, sempre facilmente derrotados e seguidos da instalação de um novo sistema de dominação, melhor, mais eficaz e aperfeiçoado ${ }^{42}$.

Um dos elementos da construção de Marcuse para a abordagem do tempo presente são as análises de Max Horkheimer sobre o declínio da autoridade paterna, na passagem do capitalismo de livre iniciativa para o capitalismo organizado dos grandes monopólios de poder econômico, político e cultural ${ }^{43}$. Essa transformação da dinâmica de acumulação e das relações de produção retira as bases da função socializadora da família, atingindo os mecanismos essenciais da constituição da individualidade e expressando o eclipse do indivíduo liberal na sociedade tecnológica ${ }^{44}$. No sistema de administração objetiva vigente, parece que os indivíduos "saltam" justamente a fase da individualização: "o átomo genérico torna-se diretamente um átomo social", em um processo de socialização do qual estão ausentes as experiências efetivamente pessoais. "A organização repressiva das pulsões parece ser coletiva e o ego parece ser prematuramente socializado por todo um sistema de agentes e agências extrafamiliares. Já no tempo pré-escolar, a vizinhança, o rádio e a televisão fixam os padrões comuns da conformidade e da revolta. Os desvios desses padrões não são tanto rechaçados no seio da família, quanto fora dela e contra ela. Os especialistas dos meios de comunicação de massa transmitem os valores requeridos; eles oferecem o treinamento perfeito de dedicação, perseverança, personalidade, sonho $e$ romantismo. Com essa educação, a família não consegue mais competir ${ }^{45}$.

Todavia, a peculiaridade de Eros e civilização não está tanto no diagnóstico do presente quanto no movimento de reconstrução dos conceitos de Freud, de modo a resguardar uma dimensão anterior aos mecanismos de controle das consciências. Como observa Kellner, "EC surge em uma década em que as culturas filosóficas pessimistas estavam largamente generalizadas nos círculos intelectuais, e em que cientistas sociais declaravam o fim da ideologia, o que significava o fim dos projetos utópico-revolucionários de reconstrução social. Nesse clima de desespero cultural entre os intelectuais de esquerda e de conformidade entre os teóricos sociais dominantes, Marcuse voltou-se ao estudo e à defesa das idéias mais radicais da herança cultural ocidental. A segunda metade de EC contém esboços da filosofia utópica de Marcuse e traços de sua noção de uma civilização

${ }^{42}$ Cf. MARCUSE, Herbert, 2004 [1955], pp. 80-82.

${ }^{43}$ Cf. HORKHEIMER, Max, 1985 [1936].

${ }^{44}$ Cf. MARCUSE, Herbert, 2004 [1955], p. 86.

${ }^{45}$ MARCUSE, Herbert, 2004 [1955], ambas as citações p. 87 - grifo no original. 
não-repressiva" 46 . É em Eros, a pulsão de vida, que Marcuse vai localizar essa "natureza não maculada, anterior à razão (instrumental)"47, na qual habita a possibilidade da emancipação. Para chegar a isso, Marcuse tem de reinterpretar Freud, distanciando-se de seu diagnóstico acerca da necessária repressão de Eros para qualquer desenvolvimento da cultura e da civilização. De uma maneira simples, para Freud, a ampla liberação das pulsões de vida sob o princípio do prazer significaria a "sexualização" da existência e, portanto, a impossibilidade da sublimação que, regida pelo princípio de realidade, seria a fonte criadora da civilização. Para Marcuse, diversamente, a liberação das pulsões de vida, possível somente em uma sociedade liberada, levaria à "erotização" da existência, desenvolvendo a dimensão estética da experiência humana e tornando possível a felicidade, simultaneamente coletiva e individual. Nesse registro, então, talvez se pudesse dizer que também em Eros $e$ civilização Marcuse realiza uma "proeza interpretativa" para não ceder a um diagnóstico no qual não há espaço para a possibilidade da transformação emancipatória das relações sociais $^{48}$.

O mesmo não se pode dizer de seu livro mais conhecido, $O$ homem unidimensional $^{49}$, que ele publica em 1964, dez anos após sua incorporação à Universidade Brandeis de Massachusetts e de seu casamento com Inge Neumann, viúva de Franz Neumann, seu companheiro de Instituto e de trabalho no Departamento de Estado estadunidense. Como os intérpretes apontam, de modo geral, trata-se da obra "pessimista" de Marcuse: "Há [...] uma ruptura significativa entre o otimismo militante de Eros e Civilização e a ênfase afirmativa nas 'tendências liberalizantes' no Marxismo soviético em contraste com o pessimismo desolado de $\mathrm{O}$ homem unidimensional" ${ }^{\prime 50}$. De fato, em Eros e civilização, por exemplo, Marcuse apontou com distinção as forças de resistência e de emancipação presentes na dimensão estética. Já em 1964, mesmo fazendo referência a essas manifestações, nota-se uma adesão menos manifesta às suas possibilidades efetivas de provocar mudanças. É como se a dimensão bidimensional e, portanto, dialética do pensamento, ofuscada passo a passo durante o andar do século $\mathrm{XX}$, tornasse-se quase completamente opaca nesse contexto. Desse modo, tematiza o desaparecimento, na experiência contemporânea da sociedade tecnológica, da distinção entre o existente e o

\footnotetext{
${ }^{46}$ KELLNER, Douglas, 1984, p. 171.

${ }^{47}$ LOUREIRO, Isabel Maria, 1998, p. 114.

${ }^{48}$ Cf. LOUREIRO, Isabel Maria, 1998.

49 Referir-me-ei sempre dessa forma a esse livro de Marcuse, o qual, no Brasil, por motivo que me é estranho, foi publicado com o título A ideologia da sociedade industrial, que é o subtítulo do original.

${ }^{50}$ KELLNER, Douglas, 1984, p. 364 - aspas no original.
} 
possível, reduzidos a uma única dimensão na qual somente aquilo que existe é o que pode e o que deve existir.

Elementos empíricos que justifiquem essa linha de raciocínio não faltam nesse livro, no qual a crítica perpassa diversos fenômenos da sociedade contemporânea, como as correntes filosóficas 'conformistas' (o operacionalismo); a linguagem do dia-a-dia, que incorpora os traços destrutivos dessa sociedade extremamente competitiva; e as expressões e as formas de produção da ideologia repressiva, desde os jogos de entretenimento, passando por jornais noticiosos televisivos e impressos até a subsunção da técnica ao processo tecnológico capitalista, procedendo ao estabelecimento de um completo aparato de dominação.

O ponto a enfatizar aqui refere-se especificamente à discussão sobre a lógica da dominação no capitalismo avançado. Retomando processos fundamentais do desenvolvimento capitalista de meados do século, entre os quais a reorganização burocrática da administração da esfera produtiva e a concomitante expansão das funções intelectuais especializadas e profissionalizadas, Marcuse aponta a domesticação do "sujeito empírico universal" da revolução, tal como fora definido pela teoria da história de Marx. " $O$ novo mundo do trabalho técnico produz assim um enfraquecimento da posição negativa da classe trabalhadora: a última não aparece mais como a contradição viva da sociedade existente ${ }^{51}$. A identificação dos trabalhadores com o ideal do estilo de vida dominante na sociedade da produção e do consumo ilimitados de mercadorias significa, em uma palavra, a supressão das experiências, no interior das estruturas estabelecidas, capazes de gerar negatividade. Ainda que o controle da produção estivesse nas mãos dos trabalhadores, isso não levaria a uma mudança qualitativa mas, pelo contrário, à manutenção do aparato tecnológico de dominação ${ }^{52}$.

Nessa redefinição do estatuto do trabalhador, no que se refere à sua relação subjetiva com a sociedade capitalista, Marcuse filia-se ao ponto de vista consagrado na literatura da época ${ }^{53}$. Desse modo, adota a conceituação que trata dessa mudança nos termos da diminuição do grau de participação do trabalho manual fabril, denominado de blue collar (colarinhos-azuis), favorecendo uma presença crescente de funcionários de escritório, os white collar (colarinhos-brancos). Estes, vendo-se mais próximos dos níveis de chefia tanto em termos da atividade exercida quanto da experiência de consumo, endossam, objetiva e subjetivamente, o modo de vida preconizado pela racionalidade tecnológica. Reproduzem,

\footnotetext{
${ }^{51}$ MARCUSE, Herbert, 2004 [1964a], p. 52.

${ }^{52}$ Cf. MARCUSE, Herbert, 2004 [1964a], p. 263.

${ }^{53}$ Cf. MARCUSE, Herbert, 2004 [1964a], pp. $42-54$ e p. 58.
} 
por conseguinte, a apropriação da técnica pela razão tecnológica, submetendo-a aos requisitos do desenvolvimento repressivo e colocando-a a serviço da submissão dos seres humanos a esse aparato.

O grau de desenvolvimento atingido pelas forças produtivas em si aponta, de modo cada vez mais inequívoco, para a possibilidade de realizar a satisfação das necessidades básicas para toda a humanidade. Nos Estados Unidos, onde esse processo está bastante adiantado, ganha força o diagnóstico do fim das contradições e dos conflitos de classe, já que o nível de produção do excedente passa a permitir o acesso dos trabalhadores aos produtos classificados como bens de consumo de luxo. Na esteira do fim do conflito de interesses entre a burguesia e o proletariado, ou entre o patrão e o trabalhador, unidos na busca em promover a contínua expansão da produtividade, anuncia-se o fim das ideologias e das utopias. Em um mundo no qual todos os grupos sociais partilham os mesmos interesses, não há sentido em contestar o existente visando sua transformação. Ao remeter à realidade concreta, que fomenta a manutenção da escassez e, portanto, a reprodução da lógica da dominação e do controle, ele revela o modo paradoxal como esse sistema operacionaliza a racionalidade, domesticando o caráter emancipatório da razão, e subjugando-a por meio do aparato.

Uma questão importante para ele está posta nas contradições engendradas por esse desenvolvimento. $\mathrm{O}$ mesmo processo que integra e conforma os indivíduos produz, como decorrência desse progresso material, uma série de contradições internas à estrutura da sociedade capitalista. A existência e, notadamente, o aprofundamento dessas contradições pode vir a fomentar formas de dissenso, com ênfase sobre a realização de um trabalho de esclarecimento que faça os indivíduos atentarem para esse caráter paradoxalmente dual da sociedade capitalista avançada. Desse modo vem à tona, em seu pensamento, a noção do que posteriormente será denominado dialética da libertação, em que o mesmo avanço das forças produtivas, utilizado de modo a reprimir as possibilidades de transformação da realidade, pode dar origem à eliminação da escassez.

Não deixa de ser notável que Marcuse tenha chegado a esse diagnóstico alguns poucos anos antes da eclosão dos movimentos contraculturais. Penso que se poderia dizer que, tendo detectado os modos de controle e domesticação da negatividade no interior do sistema produtivo, ele estava no 'lugar' certo para enxergar a potencialidade da recusa da sociedade tecnocrática na contracultura de grupos sociais 'secundários' às relações de produção fundamentais, no sentido definido por Marx. Em sua concepção da relação entre o presente dado e o futuro possível, localiza-se uma das motivações que proporcionaram a 
ênfase sobre os sentidos críticos dos movimentos sociais dos anos 1960 presente em sua interpretação posterior.

Kellner chama a atenção para essa mudança de ênfase, que é vista por muitos intérpretes como uma inflexão na trajetória de Marcuse. "Essa é, de fato, a perspectiva da maioria dos escritos de Marcuse após 1965. Marcuse é um barômetro histórico sensível, e quando novas contradições, fatores de desintegração e crises emergem nos anos 1960, fazendo possivel, novamente, a mudança social radical, Marcuse rapidamente apóia as novas forças de rebelião e volta a reconsiderar as teses marxistas que ele havia temporariamente posto em questão ou rejeitado" ${ }^{, 54}$. Discordo parcialmente dos termos de Kellner, referentes a um retorno de Marcuse a concepções marxistas que teria anteriormente rejeitado. A meu ver, ele de fato não indica, em $O$ homem unidimensional, perspectivas concretas de emancipação, em virtude da impossibilidade de identificar, no horizonte do debate 'político' posto, qualquer prática que apontasse para uma negação do existente. Mas isso não significa que ele afirme que as contradições desapareceram; pelo contrário, a idéia da contradição está no cerne do seu diagnóstico da sociedade unidimensional, conforme o seu entendimento do que seja uma análise dialética ${ }^{55}$.

É, inclusive, nesse quadro, que, em sua abordagem teórica e seus diagnósticos, Marcuse nada contra a corrente daquele período na comunidade intelectual dos EUA, que tematizava, acriticamente, os avanços da sociedade afluente. "Ao criticar, de forma tão incisiva, a sociedade americana contemporânea, Marcuse, simultaneamente, foi contra a corrente do pensamento acadêmico conformista e antecipou as críticas multifacetadas à sociedade americana que emergiriam ao longo dos anos 1960. [...] O homem unidimensional fornece uma teoria de uma época histórica durante a qual a oposição radical estava em baixa e a afluência capitalista e a repressão prevaleciam" ${ }^{\text {. }}$.

\footnotetext{
${ }^{54}$ KELLNER, Douglas, 1984, p. 274.

${ }^{55}$ Considero que o próprio Kellner está ciente desse aspecto, visto que, ao início de sua interpretação de O homem unidimensional, faz questão de destacar a importância dos elementos de uma análise dialética da realidade, sempre presentes no pensamento marcuseano: "Desde que, entretanto, Marcuse critica as relações 'unidimensionais' por meio de alternativas pelas quais se deve lutar e que devem ser realizadas, é errado ler Marcuse como um teórico da sociedade totalmente administrada, que rejeita completamente a contradição, o conflito, a revolta e o pensamento e a ação alternativas. Como há passagens em $\mathrm{O}$ homem unidimensional e seus trabalhos posteriores que colocam em dúvida essa interpretação, é um erro interpretar $\mathrm{O}$ homem unidimensional simplesmente como o épico da dominação total numa tentativa quasi-hegeliana de subsumir tudo a uma totalidade monolítica”. KELLNER, Douglas, 1984, p. 235 aspas no original. Fica patente, portanto, que não se pode falar de uma rejeição de quaisquer teses marxistas mas, no máximo, da crítica de algumas categorias analíticas (como a do proletariado como força negativa), ponto explicitamente frisado por Marcuse como procedimento correto, não-dogmático, do pensador marxista.

${ }^{56}$ KELLNER, Douglas, 1984 , p. 242. George Cotkin partilha do mesmo diagnóstico quanto à atmosfera intelectual, destacando o conformismo acadêmico que se disseminou no pós-guerra. Afirma que "há
} 
No âmbito da minha ponderação em face das considerações de Kellner acerca de percalços ocorridos no pensamento de Marcuse, entendo que o caráter destoante de sua teoria naquele contexto intelectual comprova a manutenção da crítica radical em sua teorização. Ele poderia, efetivamente, ter abandonado o viés marxista, o que até mesmo facilitaria a sua vida em termos de aceitação acadêmica, mas não o fez.

$O$ homem unidimensional expõe uma interpretação do funcionamento do aparato de dominação, cuja acuidade intelectual foi, a meu ver, comprovada pelo caráter dos movimentos sociais de protesto, notadamente em dois sentidos principais. Primeiramente, a organização da resistência não teve a sua origem entre os trabalhadores industriais, mas em uma constelação de grupos que transcendiam o caráter da oposição de classe. Tratou-se, predominantemente, de setores inseridos no epicentro do sistema de produção e reprodução da ciência e da tecnologia capitalistas, que expressavam, a partir dessa posição, certa consciência das contradições imanentes a esse sistema. Em segundo lugar, esses grupos e indivíduos projetaram a sua revolta precisamente contra o âmago da lógica da civilização tecnológica, reconhecendo a sua associação intrínseca com a dominação e a repressão e rejeitando, por conseguinte, os principais valores que norteiam a experiência capitalista, pautada pela ideologia da sociedade afluente.

justiça em enfatizar como temas definidores dos intelectuais do pós-guerra seu movimento do radicalismo para o conservadorismo, de um posicionamento antagônico para um celebratório vis-à-vis a América, ou de comprometimentos ideológicos para o ideal de um 'fim da ideologia"'. COTKIN, George, 1997 , p. 251 - aspas no original. Cf. ainda BIEL, Steven, 1997. Considero haver poucas, mas notáveis, exceções a esse processo de 'conformação' ou 'integração' do pensamento nos EUA de meados do século XX. Russell Jacoby, em uma análise crítica da profissionalização da pesquisa como fator desencadeador do conformismo dos intelectuais norte-americanos, ocorrido no bojo do declínio da boemia nas décadas de 1920 e 1930, destaca o sociólogo Charles Wright Mills como a única exceção. Cf. JACOBY, Russell, 2000 [1987], pp. 115-119. Apesar de terem perspectivas teóricas extremamente diferentes, Mills e Marcuse apresentam semelhanças em diversos aspectos dos diagnósticos que fazem da sociedade presente, a saber: (i) a crítica ao desenvolvimento da civilização, que paradoxalmente destrói os valores que a sustentam, isto é, a razão e a liberdade; (ii) a crítica da sociedade e da cultura de massas como mecanismo de reprodução da alienação, nas palavras de Marcuse, ou do embotamento da consciência, nas de Mills; (iii) a crítica ao patente conformismo da sociologia positivista profissionalizada e, finalmente, (iv) o fato de imputarem a origem dessa situação às mudanças na esfera do trabalho, sendo Mills, o autor do conceito da nova classe média (white collar). Nesse contexto, ele aborda a crescente despolitização - a privatização das questões públicas e a indiferença em relação à esfera pública - da população, diretamente relacionada à reestruturação da configuração sócio-política a partir do trabalho: "Durante um período considerável, a velha classe média era uma base de poder independente. A nova classe média não o pode ser. A liberdade política e a segurança econômica estavam ancoradas nas propriedades pequenas e independentes; não estão ancoradas nos mundos do emprego burocráticos. Os proprietários dispersos estavam economicamente unidos pelos mercados mais ou menos livres; os empregos da nova classe média estão integrados pela autoridade das empresas em conjunto. Economicamente, as classes burocráticas estão nas mesmas condições dos assalariados; politicamente, estão em condições piores, pois não se organizaram. Não são a vanguarda da transformação histórica; na melhor das hipóteses, são a retaguarda do Estado de bem-estar social'. MILLS, Charles Wright, 1965 [1958], p. 37 - grifos no original. Cf., ainda, Id., 1951 e 1959 e HOROWITZ, Irving Louis, 1965. 
Essa concepção da ideologia compõe o diagnóstico marcuseano de uma realidade que apresenta marcadas contradições. A manutenção da forma-mercadoria e do capital determinam a perpetuação do reino da necessidade, no sentido da exploração dos homens e da natureza, assim como da luta pela existência. O que está subjacente a essa lógica é o princípio de desempenho, que impele ao desenvolvimento sempre maior das forças produtivas, o que, no contexto da racionalidade tecnológica, perpetua a escassez, mas, paradoxalmente, fornece as condições materiais para a realização do reino da liberdade. No quadro do capitalismo organizado, a ideologia da liberdade existe meramente enquanto consumo de bens simbólicos e materiais ad nauseam, compreendendo o concomitante sacrifício para a aquisição da capacidade de compra, apesar da possibilidade objetiva da extinção da exploração e da alienação.

Em segundo lugar, no fomento de relações sociais regidas pela competição entre os indivíduos, o que reproduz incessantemente o aparato de destruição em diversos níveis e formas, como na linguagem, caracterizada por traços repressivos da sociedade patriarcal, racista e sexualizada, e na guerra entre os Estados-nacionais, pela imposição a qualquer custo (humano e material) de padrões civilizacionais que dão origem somente a uma cultura de caráter afirmativo, que impede o desenvolvimento da autonomia individual. Finalmente, a dimensão autoritária da democracia de massas, que concede o status de liberdade à pseudocultura e à pseudopolítica praticadas nessa sociedade, em cujo âmbito a escolha recai somente sobre os produtos acabados, restrita à opção entre possibilidades previamente estabelecidas, por um modelo da calça de marca, por um estilo pré-catalogado de música, por um candidato entre os políticos que integram a lista fechada.

É no quadro dessa crítica que $O$ homem unidimensional acabou por ser referência para os movimentos, em especial, o movimento estudantil. A adoção, fosse ela explícita ou não, de muitos dos conceitos criados e utilizados em suas obras, como o da sociedade unidimensional, da grande recusa, da nova sensibilidade, entre outros, é inegável ${ }^{57}$.

\footnotetext{
${ }^{57}$ Em panfleto estudantil do grupo Radical Action Cooperative (Cooperativa da ação radical), de 1968, encontra-se a seguinte passagem, flagrantemente similar à argumentação de $O$ homem unidimensional: " $O$ absurdo fantástico desse sistema é revelado na sua necessidade de criar necessidades artificiais. Não foi suficiente, somente, abarrotar o consumidor de produtos reais, pois ele ficou satisfeito a ponto de ameaçar não mais consumir. Então o sistema teve de criar necessidades para produtos irreais. Milkshakes sem leite, gordura desengordurada (ou margarina de imitação) etc. Outras mercadorias artificiais permitem nossa alienação de nós mesmos: cosméticos, desodorantes, etc. O ser humano moderno consome a si mesmo, fora da existência". Citado em WALLERSTEIN, Immanuel e STARR, Paul, 1971, vol. 1, p. 121. Um panfleto de 1967, escrito pelo líder estudantil Carl Davidson, também apresenta fortes semelhanças, como na passagem: "No passado, o trabalho de ensino e aprendizagem era um processo de mão-dupla, com a dialética socrática como a sua forma mais pura. Entretanto, com o advento do Estado corporativo, e a sua correspondente apropriação do aparato cultural, a educação
} 
Por outro lado, a percepção de um sentido crítico dos movimentos, de sua constituição como um vetor importante para, ao menos, organizar o protesto em bases diferentes da prática política tradicional em que se encontravam inseridos os partidos e os sindicatos, efetivamente marcou a teoria social marcuseana posterior. Essa interpretação persistiu durante o restante de seus escritos e de suas palestras. Contudo, jamais rendeu-se a endossar descompromissadamente e sem rigor os movimentos sociais daquele período. Pelo contrário, preocupou-se, novamente, em apontar as contradições internas e os limites das formas de protesto e organização, jogando luz sobre o diagnóstico da sociedade de classes e indicando, assim, algumas balizas que deveriam estar presentes em quaisquer formas de resistência que visassem obter algum sucesso.

Ao final da década de 1960, após ter sido dispensado de Brandeis, por motivos atribuídos extra-oficialmente a problemas ideológicos, e aceitado o convite da Universidade de San Diego, Marcuse esteve, durante alguns meses, em diversos países da Europa, proferindo palestras e participando de debates sobre os movimentos sociais, notadamente, o movimento estudantil, que tiveram grande repercussão. Após o retorno à Califórnia, ele dá continuidade a essa atuação, vendo-se às voltas com as mais diversas ameaças, em virtude de sua rotulação como ativista da esquerda radical. O seu livro de 1972, Contra-revolução e revolta, reúne alguns trabalhos do período, nos quais Marcuse elabora os termos de seu entendimento da revolução cultural no contexto do capitalismo avançado e de suas potencialidades transformadoras da sensibilidade humana, capaz de "dissolver a familiaridade opressiva com o mundo objetal" que condiciona nossa existência na sociedade alienada ${ }^{58}$.

Nos anos seguintes, após a morte de sua segunda esposa, Inge, Marcuse retoma em especial os temas estéticos do início da carreira, fazendo uso desse ponto de vista para discutir a arte e a revolução. Pode-se observar ligações entre as concepções esboçadas no início de sua carreira acadêmica no trabalho sobre o romance moderno e o seu último livro, A dimensão estética, quanto ao sentido crítico da imaginação artística. "Dessa maneira, ela alcança a dimensão em que a sua própria subversão da experiência torna-se possível: a arte moldada no mundo é reconhecida como realidade, que é reprimida e falsificada no mundo real. Essa experiência culmina nas situações extremas representadas na própria obra (no amor, na morte, no tornar-se culpado, no fracassar; mas também na felicidade, na realização). Nessas situações, a sociedade está colocada em xeque - em nome de uma

tornou-se crescentemente unidimensional". DAVIDSON, Carl, 1971 [1967a], p. 97. Cf. também Id., 1971 [1967c], pp. 137 e 138.

${ }^{58}$ MARCUSE, Herbert, 2004 [1972], p. 75. 
verdade 'normalmente' não mais atuante: a obra de arte coloca-se desde o início, em virtude de sua concepção, em situações nas quais aparecem uma razão e uma sensibilidade

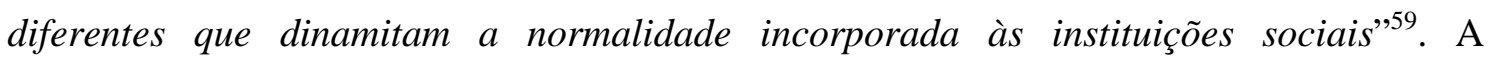
dificuldade de compreender a (verdadeira) obra de arte explica-se pela sua diferença em relação aos padrões da normalidade. Não há conformidade aceitável para o artista cuja obra é produto do estranhamento face à existência cindida do mundo alienado.

Em meio ao retorno aos temas estéticos, sem abandonar o problema central da negatividade possível, Marcuse casa-se pela última vez com a ex-aluna Erica Sherover. Três anos depois, em 1979, vem a falecer na Alemanha, deixando como legado um percurso claramente marcado pela recusa do conformismo. Debruçar-se sobre sua obra, com espírito crítico, dedicar-se a compreender melhor sua criação intelectual, representa um esforço, ainda que imensamente limitado, de apropriar-se dessa herança.

\section{$* * *$}

A reconstrução, traçada em largas pinceladas, do percurso intelectual de Marcuse, permitiu indicar como as questões que estão na base de sua interpretação acerca da dominação e das possibilidade da mudança social estiveram, desde o início, presentes em seu horizonte. Notadamente, são duas as questões que servem de baliza ao pensamento expresso nos quatro textos aqui traduzidos.

No diagnóstico crítico da sociedade capitalista do autor a crítica da forma de racionalidade vigente, pautada, sob o capitalismo, pelo objetivo do controle e da dominação dos seres humanos e da natureza, é questão fundamental. Por outro lado, em contraposição a esse mundo violento, que perverte, pela razão, o desenvolvimento histórico da liberdade, Marcuse busca a liberdade no sentido da autonomia, posicionando-se a partir da perspectiva da emancipação da pessoa em uma sociedade humanizada. Em seu pensamento, isso revelase na importância concedida à questão dos sujeitos históricos da transformação radical. Essas duas questões gerais em torno da lógica da dominação na sociedade industrial alienada e das possibilidades da negação do paradoxo da civilização tecnológica pautada pela utopia da humanização marcam a prática teórica marcuseana e, por isso, permitem, a meu ver, situar as posições de Marcuse nos textos aqui apresentados em língua portuguesa.

${ }^{59}$ MARCUSE, Herbert, 2004 [1977], p. 201 - aspas no original. 


\section{Capitalismo organizado e sociedade tecnológica: a dominação tecnocrática}

\subsection{Sociedade e tecnologia: a dominação 'racional'}

Os temas da tecnologia, da ciência e do seu envolvimento com a sociedade industrial moderna são distintivos do legado intelectual de Marcuse. Entretanto, até os anos 1940, a sua atenção ainda costumava centrar-se, em maior parte, sobre questões de crítica da ideologia e da cultura, assim como sobre a análise da filosofia ou história da filosofia, dedicando-se às interpretações do pensamento de Marx. Inclusive, é de 1941 a publicação de uma de suas obras mais conhecidas, Razão e revolução, em que são delineados os aspectos que ligam a filosofia de Hegel às idéias elaboradas por Marx.

Nesse sentido, seu artigo de 1941, "Algumas implicações sociais da tecnologia moderna" ${ }^{\circ 0}$, marca o surgimento da temática científico-tecnológica, que virá ampliar o leque de temas contemplados pela crítica da ideologia e da cultura. Decorrente, em parte, de sua ida aos Estados Unidos, onde a tecnologia, no sentido de um aparato de dominação produtor de uma racionalidade repressora do desenvolvimento da subjetividade crítica, encontra-se em seu estágio mais avançado, Marcuse tomará como um eixo fundamental esse modelo de produção da 'cultura' (ou, melhor dizendo, da 'não-cultura', que é a cultura subsumida pela civilização), tributário da forma de desenvolvimento da racionalidade capitalista.

Desse modo, no texto sobre a tecnologia moderna, vê-se a inclinação de seu pensamento para a análise do capitalismo industrial enquanto civilização tecnológica, caráter que se aprofundará após a Segunda Guerra Mundial. As idéias aqui preliminarmente apresentadas pelo autor constituem o esboço do que acabou por ser desenvolvido, em especial, no capítulo sexto de sua obra $O$ homem unidimensional.

Uma especificação fundamental explicitada por Marcuse logo ao início do texto é a distinção entre técnica e tecnologia. A técnica é apenas um fator parcial da tecnologia, que é, em si mesma, neutra, podendo servir a várias perspectivas de valor, como comprova

\footnotetext{
${ }^{60}$ Cf. MARCUSE, Herbert, 1980 [1941]. O texto em questão foi publicado em 1941 na edição inglesa da Revista do Instituto Zeitschrift für Sozialforschung (Studies in Philosophy and Social Science). Utilizei também, para a tradução, a versão publicada em KELLNER, Douglas (Ed.). Tecnologia, guerra e fascismo. Trad. Maria Cristina Vidal Borba. Rev. da trad. de Isabel M. Loureiro. São Paulo, UNESP, 1999, pp. 71-104. Somente neste sub-item indiquei toda a referenciação desse artigo no corpo do texto, seguindo a paginação da publicação original.
} 
historicamente a tecnocracia do terceiro Reich. Já a tecnologia é o modo de produção que compreende a totalidade dos instrumentos, dispositivos e invenções da era da máquina, assim como a forma da organização das relações sociais, das manifestações do pensamento e dos padrões de comportamento dominantes (cf. p. 414).

A tecnologia é, assim, entendida como um processo social que diz respeito à implementação de um dado tipo de racionalidade. A racionalidade tecnológica é a eficiência lucrativa posta a serviço dos grandes monopólios, ou seja, constitui o aparato tecnológico. Sua verdade é a de uma instrumentalidade, composta de seqüências pré-determinadas de meios e fins, que reconstituem, pouco a pouco, os padrões do julgamento individual, o que acaba por fazer com que os meios, que outrora balizavam o exercício desse forma de racionalidade, tornem-se o próprio fim (cf. p. 417). É precisamente esse procedimento de introjeção de valores, impulsionado pelo avanço da tecnologia no processo de erosão do sujeito econômico livre, que cerceia a projeção do indivíduo dotado de razão crítica.

Eis a importância que precisa ser concedida à distinção entre técnica e tecnologia. É a forma vigente do processo tecnológico que transforma, na atualidade, a técnica num elemento contrário à razão crítica, fomentando exclusivamente o conformismo social. Essa posição sustenta a recusa de Marcuse dos movimentos contra o desenvolvimento técnico, defensores de uma volta à natureza, que não conseguem propor uma alternativa emancipatória à sociedade industrial. Para Marcuse, eles visam o alvo errado, e tendem a alinhar-se, afinal, à "tecnocracia terrorista". Segundo ele, "a filosofia da vida simples, a luta contra as grandes cidades e a sua cultura freqüentemente servem para fomentar nos homens a desconfiança frente aos instrumentos potenciais de sua libertação" (p. 437) e a "técnica atravanca o desenvolvimento individual apenas na medida em que está ligada a um aparato social que perpetua a escassez; esse mesmo aparato liberou forças que podem abalar a forma histórica específica em que a técnica é utilizada" (p. 436).

Para elucidar a nova forma de racionalidade advinda da tecnologia desenvolvida no capitalismo monopolista, Marcuse retoma a interpretação do que ele denomina racionalidade tradicional, distinguindo, afinal, dois padrões de individualidade (cf. p. 415) ao longo do desenvolvimento do capitalismo ${ }^{61}$. A idéia de indivíduo nos séculos XVI e XVII refere-se a um sujeito cujos padrões e valores fundamentais estão protegidos de toda autoridade externa. Racional, ele é livre para buscar, de modo autônomo, as formas verdadeiras de sua existência. Em uma sociedade que não era, ainda, racionalizada, o

${ }^{61}$ Cf. HORKHEIMER, Max, 1985 [1946]. 
puritanismo radical posiciona o indivíduo contra a sua sociedade. Autonomia, racionalidade crítica e questionamento dos padrões vigentes balizam a concepção da individualidade.

Ao final do século XIX, com o tipo de desenvolvimento do modo de produção, elementos de resignação cada vez mais fortes atingem a filosofia individualista. A contraposição entre indivíduo e sociedade não aponta mais para a mudança da sociedade, mas para o afastamento do indivíduo do mundo social. Da alma livre que critica a autoridade externa passa-se à alma - o íntimo, o privado, o pessoal - como refúgio contra as autoridades externas em expansão no cenário do desenvolvimento histórico da racionalidade da competição, fundada na escassez.

O desenvolvimento da indústria sob o prisma da racionalização e da mecanização solapa as bases econômicas do sujeito livre (cf. p. 416). O processo de padronização, concentração e monopolização destrói a livre concorrência e a iniciativa individual e põe as bases da moderna sociedade de massas, que quantifica os atributos qualitativos do trabalho individual e padroniza os elementos da cultura do indivíduo independente nas atividades da cultura intelectual (cf. p. 436). Ele torna a individualidade desnecessária; ela agora limita-se apenas à escolha dos meios para a realização do fim, já dado, da eficiência lucrativa. Seu horizonte não ultrapassa a factualidade, o auto-interesse imediato, que reafirma a racionalidade tecnológica, e a inserção instrumental do homem no mundo.

É nesse sentido que Thorstein Veblen (cf. pp. 417 e 418) expõe a idéia de que o homem passa a estar obrigado a adequar-se e submeter-se às máquinas, processo esse que se consolida numa nova forma de socialização cujo signo é o da eficiência, medida a partir de critérios padronizados e quantitativos, que uniformizam os indivíduos, anulando as qualidades. O ser humano não precisa mais tomar decisões no enfrentamento das situações do dia-a-dia; mais do que isso, ele é impelido a deixar de fazê-lo, já que as funções especializadas levam a que haja pessoas que já analisaram todas as possibilidades de uma certa situação, seguindo a racionalidade tecnológica ideal à preservação das máquinas. Dessa forma, as escolhas, análises, indicações e sugestões já estão feitas e explicitadas por outros na forma de manuais, placas, etc. Só é necessário segui-las; os indivíduos são agora comandados pelos poderes sociais. Desse modo, ocorre a "naturalização" ou "normalização" dessa forma de agir; a resistência é considerada irracional por parte de cada indivíduo (p. 421). Afinal não é imaginável, nessa lógica de ação, que alguém venha a postular a necessidade de refletir acerca de cada escolha; "o ponto decisivo é que essa atitude - que transforma todas as ações numa seqüência de reações semi-espontâneas a 
normas mecânicas prescritas - não é apenas perfeitamente racional, mas também perfeitamente razoável" (p. 419).

Estão envolvidas nesse diagnóstico as dimensões da autonomização tecnológica em relação aos valores humanos e da 'exacerbação' do fetichismo nos moldes marxianos, pela formação da identidade na relação com as coisas, na personificação das mercadorias, como no caso do tratamento do automóvel como um ser humano (cf. p. 420). O processo despe os indivíduos de sua individualidade e racionalidade crítica, tornando-os tanto adaptados a essa nova ordenação quanto conformistas em face dela. A psicologia industrial passará a tratar a adaptação ao existente como "natural", ao considerar certos comportamentos humanos resultantes dessa racionalização como padrões inerentes ao ser humano. Esse ajustamento, promovido pela administração científica, estava presente, por exemplo, em F. W. Taylor, cuja atuação é rapidamente comentada no artigo. Taylor foi um notório executor da idéia da divisão do trabalho, discutida, entre outros, por Adam Smith. Taylor propunha uma especialização em graus bastante aprofundados, envolvendo um trabalho minucioso de averiguação da capacidade de cada pessoa em executar uma tarefa. No estágio alcançado pela especialização, a sub-divisão das tarefas é efetuada até de acordo com os órgãos e as partes do corpo humano (cf. p. 437). Tal processo acarreta uma forma de padronização da atividade individual que alude a uma pretensa naturalização dessa constituição do ser humano vis à vis a tecnologia vigente, como se esses padrões social e tecnologicamente conformados decorressem de aptidões biologicamente inscritas em todos, tomando o sujeito como o suporte de funções produtivas especializadas. Cada pessoa há de ser educada de forma que possa preencher as funções disponíveis sob a égide da tecnologia, inserindo-se heteronomamente na divisão do trabalho vigente.

A existência da multidão é um dado fundamental dessa nova forma de socialização (cf. p. 426). As massas e os indivíduos que meramente as compõem passam a ser vistas funcionalmente no que se refere ao preenchimento das e adequação às profissões; pessoas são capacitadas a exercerem uma certa função especializada, vivendo numa rede de formação instrumental, visando um fim estrito. A ideologia do treinamento vocacional (cf. p. 427) está de acordo com isso, ao preparar cada indivíduo para sua função específica. Assim, a procura pelo interesse pessoal traz consigo que "o tipo de indivíduo prevalecente [...] mudou a sua função; de uma unidade de resistência e autonomia ele passou para uma de docilidade e ajustamento" (p. 428).

Com isso, a autonomia e a heteronomia do sujeito passam a ser vistas com as suas atribuições críticas invertidas: é o declínio do valor concedido à autonomia, a qual passa a 
ser avaliada como um entrave à ação racional. Esse fenômeno expressa-se na dissolução ou impotência do pensamento crítico (cf. pp. 424 e 425). Parece não haver mais possibilidade alguma de uma visão da totalidade dos acontecimentos, pelo fato de a manutenção das condições de sobrevivência do indivíduo ver-se intrinsecamente associada à reprodução das máquinas e do aparato produtivo especializado. O registro em que está inserido esse ponto da análise de Marcuse é o da incorporação das organizações dos trabalhadores industriais ao aparato tecnológico. "Idéias como liberdade, indústria produtiva, economia planificada, satisfação de necessidades são então fundidas com os interesses de controle e competição. O sucesso organizacional tangível contrabalança assim as exigências da racionalidade crítica" (p. 425). A expansão do controle e a burocratização da oposição operária são elementos do modo como a racionalidade tecnológica atinge a racionalidade crítica.

Esse diagnóstico acerca da forma de dominação que, de maneira imediata, mostra tão somente um contexto reificado aponta, na abordagem histórico-materialista de Marcuse, as contradições que podem proporcionar, num movimento dialético, as possibilidades da transformação social. É notadamente a distinção inicial entre técnica e tecnologia que fornece o principal elemento para a identificação dos traços que permitem pensar uma outra estrutura social. O advento da racionalidade tecnológica proporciona, num movimento contraditório, o avanço de uma "produção massificada mecanizada [que preenche] os espaços vazios nos quais a individualidade poderia assentar-se” (p. 435). O empobrecimento cultural, a partir da massificação generalizada, projeta o irracionalismo desse novo tipo de racionalidade. Nesse mundo capaz de gerar excedentes consideráveis de produção coexistem, simultaneamente, bolsões de pobreza nas mais diversas regiões, mesmo nas sociedades "avançadas". Assim, "a padronização cultural aponta, paradoxalmente, para a abundância potencial assim como para a pobreza existente" (p. $435)^{62}$. Aparece aqui uma das contradições de um processo dialético, em que a mesma

\footnotetext{
${ }^{62}$ Os economistas Paul Baran e Paul Sweezy tratam das contradições que caracterizam o avanço do capitalismo monopolista, notadamente da exploração intensiva que ocorre sob a sua égide e que tem como uma das marcas registradas a coexistência constante de riqueza e pobreza. Cf. BARAN, Paul A. e SWEEZY, Paul Marlor, 1966, capítulo 10 ("On the quality of monopoly capitalist society") pp. 281-335. Paul Sweezy, durante uma palestra sua, procurará jogar luz sobre os efeitos do capitalismo como sistemamundo, destacando a extensão da exploração como homologia entre os países desenvolvidos e os, em sua denominação, "em subdesenvolvimento": "Através da história dos E.U.A., por exemplo, a relação entre o nordeste e o sul e o oeste tem sido essencialmente uma relação de metrópole-colônia; e é possível observarmos a mesma coisa muito claramente hoje em um país como o Brasil, onde a riqueza e a indústria estão concentradas no pequeno triângulo Rio-São Paulo-Belo Horizonte, enquanto a maior parte do restante estagna em terrivel pobreza. Até mesmo no centro do centro observamos a mesma coisa: Park Avenue e Harlem localizam-se, afinal de contas, apenas a milhas um do outro; e dos telhados dos luxuosos apartamentos de Copacabana no Rio pode-se ver, nas favelas dos morros circundantes, alguns dos bairros mais degradados [slums] do mundo" - "favelas" encontra-se em português e em itálico no original. SWEEZY, Paul Marlor, 1972 [1969], p. 21.
} 
técnica que pode produzir abundância 'universal', pondo as condições objetivas para uma mudança efetiva das relações de competição por recursos escassos entre os indivíduos, reproduz e aprofunda as desigualdades quando inserida numa lógica de dominação. Mas são essas desigualdades que podem vir a abalar a estrutura social vigente.

O aparato tecnológico, por sua vez, controla a disseminação dos conhecimentos racionais, repondo e aprofundando as diferenças entre administradores e executores, na medida em que molda a especialização das ocupações em unidades atomizadas que exigem coordenação. Desse modo, ele neutraliza as possibilidades democráticas do desenvolvimento técnico (cf. p. 430). Contudo, o progresso técnico, ao possibilitar a redução do tempo gasto na produção necessária à reprodução da vida material, poderia ser a base para a abolição da lógica da competição, abrindo espaço para o desenvolvimento do ser humano (social) a partir de suas raízes naturais (cf. p. 438). Isso poderia, então, abrir novos caminhos para o desenvolvimento da individualidade natural do homem no reino da satisfação (cf. pp. 438 e 439). Esse horizonte utópico não aponta para o estado natural de todos contra todos dos jusnaturalistas, concebido a partir de um mundo de escassez. Todavia, ele também não aponta para um estado de total felicidade, ficando aberto ao possível humano na história.

\subsection{Ciência e tecnologia sob o pensamento unidimensional}

No prefácio a $O$ homem unidimensional, Marcuse parte da racionalidade tecnológica como fundamento do aparato repressor, para explicitar as tendências da "sociedade industrial avançada", que impede o desenvolvimento de uma liberdade que seja expressão da humanização da vida. A aparente liberdade dos indivíduos é aquela limitada à esfera do consumo, na qual a 'liberdade de escolha' realiza-se às custas da humanização do indivíduo, de suas relações com os outros homens e com a natureza, repondo os pressupostos para a reprodução das relações de exploração existentes. "Como universo tecnológico, a sociedade industrial avançada é um universo político - o degrau mais tardio da realização de um projeto histórico, específico - qual seja a experiência, remodelagem e organização da natureza como mera matéria de dominação",63. Observo, por conseguinte,

\footnotetext{
${ }^{63}$ MARCUSE, Herbert, 2004 [1964a], p. 18 - grifos no original. Raras vezes Marcuse tratou do problema da revolução nos países capitalistas pobres. Em suas poucas referências, a classe trabalhadora detém um papel muito mais central nesses países, visto que a estrutura do processo de produção, neles, assemelhase, em maior grau, àquela dos países centrais, na passagem do século XIX ao XX. Por outro lado, via no
} 
que o princípio organizador da estrutura social do capitalismo monopolista pauta-se, essencialmente, por uma política de dominação da natureza.

O traço principal desse tipo de relação de submissão da natureza é a satisfação das necessidades alienadas dos indivíduos reprimidos. Isso coloca em pauta muito mais do que uma relação de exploração para a sobrevivência da espécie, no sentido da dependência humana da natureza. Constitui, na realidade, a projeção do ambiente externo como mero instrumento, a ser inteiramente explorado por uma sociedade que, dada essa base, só pode instituir as relações entre os seres sociais enquanto relação instrumental. "A produtividade $e$ o potencial de crescimento desse sistema estabilizam a sociedade e mantêm o progresso técnico no contexto da dominação. A racionalidade tecnológica tornou-se racionalidade política"64. A especificidade desse sentido de 'razão' é a sua existência como política de dominação da natureza pelos seres humanos e dos seres humanos por outros seres humanos. Essa contradição somente pode ser apreendida quando despida de seu véu ideológico, no âmbito de uma análise dialética, cujo principal substrato é o questionamento da aparência imediata da realidade. Caso contrário, o pensamento degenera na unidimensionalidade, na impossibilidade de proceder a uma análise que consiga relacionar as partes, não se dando conta dos custos e, portanto, dos sacrifícios exigidos para a manutenção desse modo de vida, e isso quando o nível do progresso técnico permitiria um salto de qualidade nas relações humanas.

Tal contradição é insolúvel enquanto for mantido o princípio de realidade vigente, isto é, o princípio de desempenho, que baseia o trabalho permanente da reprodução da racionalidade do sistema. A função da aparência ilusória de que esta realidade, apresentada de modo imediato como a realização das possibilidades da liberdade humana, seja também verdadeira, constitui um dado fundamental para produzir o conformismo. No momento e na situação descritos por Marcuse, o 'novo' tipo de trabalhador predominante (white collar) identifica-se de forma muito mais clara e imediata com o estilo de vida de seus superiores do que de seus eventuais subordinados. Desde pequenas coisas, como a alteração da estrutura física do local de trabalho, deslocada das fábricas para os escritórios, até considerações talvez mais incisivas em termos de determinações originadas da

subdesenvolvimento a possibilidade de um desenvolvimento histórico que pulasse a etapa da racionalização instrumental para a dominação. "A vantagem histórica das nações mais novas, do seu atraso técnico, talvez seja a de poderem saltar o estágio de sociedade afluente. Os povos atrasados, por sua pobreza e fraqueza, poderão ser forçados a renunciar ao uso agressivo e supérfluo da ciência e da tecnologia, para manterem a engrenagem produtiva à la mesure de l'homme, sob o seu controle, para satisfação e desenvolvimento das necessidades vitais, tanto individuais como coletivas". MARCUSE, Herbert, 1968 [1966], p. 18.

${ }^{64}$ MARCUSE, Herbert, 2004 [1964a], p. 19. 
mercadorização do mundo como um todo, as quais sejam os gostos e as formas de consumo similares. "Aqui o assim chamado equilíbrio da situação de classes mostra a sua função ideológica. Quando o trabalhador e seu chefe se divertem com o mesmo programa de televisão e visitam os mesmos locais de férias, quando a datilógrafa está arrumada de forma tão atraente quanto a filha de seu empregador, quando o negro é proprietário de um Cadillac, quando todos eles lêem o mesmo jornal, então essa assimilação não aponta para uma supressão das classes, mas para a medida em que a população submetida partilha das necessidades e satisfações que servem à manutenção do existente" ${ }^{\text {"65 }}$. Aqui está expressa a contradição desse modo de existência. Apesar dos bens e das prestações de serviços serem similares para os diversos estratos da sociedade, de modo que satisfaçam os desejos e anseios de consumo, o que traz uma aparente 'democratização' tanto das chances e possibilidades quanto da vida de fato, trata-se de um mecanismo importante de dominação nessa organização social que destitui de sentido as aspirações negativas e integra o trabalhador a esse modelo de sociedade alienada ${ }^{66}$. Ele compartilha dos desejos e das necessidades sociais; melhor dizendo, "nem os seus desejos nem a transformação da realidade continuam submetidos à sua própria decisão: eles agora são organizados pela sociedade ${ }^{67}$. As pessoas não refletem acerca do que seria uma vida melhor ou do que desejariam fazer em sua vida e ter em seus lares. Elas simplesmente aceitam o que lhes é oferecido pela sociedade de consumo. No limite, trata-se de uma identificação irrestrita com os símbolos e os valores vigentes, e que Marcuse identificará com o comportamento mimético $^{68}$. Esse é o desenvolvimento último da sociedade administrada, que se responsabiliza por planejar minuciosamente todos os aspectos da vida pessoal.

O reconhecimento de que as necessidades humanas são construídas historicamente, como Marx e Engels já apontavam em A ideologia alema $\tilde{a}^{69}$, não implica rejeitar a tarefa de pensar o que é imediatamente necessário. Ao procurar definir os preceitos básicos de uma

\footnotetext{
${ }^{65}$ MARCUSE, Herbert, 2004 [1964a], p. 28. Não faltam exemplos empíricos em sua argumentação do que seriam esses desejos repressivos e despidos de sentido, como quando responde a uma pergunta que lhe foi feita durante uma entrevista acerca desse tema: "Por exemplo a necessidade de manter a luta concorrencial pela existência - a necessidade de comprar um carro novo a cada dois anos, a necessidade de ver televisão cinco ou seis horas por dia. Para uma enorme parte da população, isso já se tornou uma necessidade vital e isso é uma necessidade que coíbe, que é agressiva e repressiva". MARCUSE, Herbert, 1998 [1967a], p. 646.

${ }^{66}$ Uma idéia flagrantemente similar à vislumbrada por Marcuse aparece em Lukács, quando este trata precisamente da eventual assimilação do proletariado no contexto da aderência ao estilo burguês, pois "surge para o proletariado tanto a possibilidade de substituir o invólucro vazio e roto pelos seus conteúdos positivos, como o perigo - pelo menos temporariamente - de submeter-se ideologicamente a essas formas completamente vazias e ocas da cultura burguesa”. LUKÁCS, Georg, 2003 [1923a], p. 410.

${ }^{67}$ MARCUSE, Herbert, 2004 [1955], p. 22.

${ }^{68}$ MARCUSE, Herbert, 2004 [1964a], p. 30.

${ }^{69}$ ENGELS, Friedrich e MARX, Karl, 1969 [1845-1846].
} 
sociedade de fato racional, não mediada pela lógica quantitativista e produtivista, Marcuse volta-se às considerações acerca dos atributos de uma vida saudável. Segundo ele, há, sim, uma distinção objetiva quanto às necessidades que detêm validade real ou que têm precedência na formação de um ser social de facto, que compreende a harmonia e solidariedade com os outros. "Podemos distinguir as necessidades reais e falsas. 'Falsas' são aquelas impostas ao indivíduo por poderes sociais particulares interessados em sua repressão: aquelas necessidades que eternizam o trabalho árduo, a agressividade, a miséria e a injustiça. [...] As únicas necessidades que têm pretensão irrestrita ao saciamento são as vitais - alimento, vestimenta e moradia no nível cultural [Kulturniveau] atingido. $O$ saciamento dessas necessidades é a condição prévia para a realização de todas as necessidades, das dessublimadas como das sublimadas"70. Por mais genérica que seja, é essa a distinção que pautará o diagnóstico marcuseano acerca das possibilidades de emancipação e da 'avaliação' do estado atual da técnica como adequado à implementação de uma sociedade liberada.

É sob essa ótica que Marcuse aponta a existência de um sistema de necessidades externo ao ser, introjetado. Todo indivíduo está despido de autonomia na medida em que suas carências são determinadas heteronomamente: ele precisa vitalmente daquilo que o aparato de produção lhe fornece. O princípio de realidade continua sendo, abstratamente, o princípio do prazer de Freud. Mas o significado do prazer encontra-se reduzido ao consumo puro de bens, submetido à sociedade da obsolescência planejada, à reificação cada vez mais imediata do indivíduo: "Os seres humanos reconhecem-se em suas mercadorias; eles encontram a sua alma em seu carro, seu aparelho de som, seus utensílios de cozinha. $O$ próprio mecanismo que ata o indivíduo à sua sociedade alterou-se, e o controle social está ancorado nas novas necessidades que trouxe à tona"71. Sob essas condições, torna-se inadmissível a rejeição dos bens que, afinal, constituem a personalidade do ser. Abdicar da

\footnotetext{
${ }^{70}$ MARCUSE, Herbert, 2004 [1964a], p. 25 - aspas e grifo no original. Marx apontou, nos Grundrisse, o mecanismo que produziu o ímpeto tanto consumista quanto produtivo associado ao desenvolvimento da sociedade capitalista: "Capital e trabalho relacionam-se, portanto, aqui, como dinheiro e mercadoria; se um é a forma universal da riqueza, o outro é somente a substância, que tem em vista o consumo imediato. Como aspiração infatigável pela forma universal da riqueza, o capital impulsiona o trabalho para além dos limites de suas necessidades naturais e cria, assim, os elementos materiais para o desenvolvimento da individualidade rica, que é tão universal em sua produção quanto em seu consumo, e cujo trabalho não mais aparece, por isso, como trabalho, mas como desenvolvimento completo da atividade propriamente dita, na qual a necessidade natural desapareceu em sua forma imediata; pois no lugar da necessidade natural pôs-se uma socialmente gerada”. MARX, Karl, 1953 [1857-1858], p. 231.

${ }^{71}$ MARCUSE, Herbert, 2004 [1964a], p. 29. Considero que nesses termos Marcuse atentou, de certa forma, para o desenvolvimento das práticas, contemporaneamente levadas ao extremo, da propaganda, da publicidade e do marketing, que se apóiam cada vez mais na identificação emocional do consumidor com o produto e a marca. Apontou, assim, os efeitos deletérios desse processo, o qual contribui de modo relevante para impedir as possibilidades de ascensão do indivíduo livre.
} 
sociedade de consumo é abdicar de si mesmo, é querer negar os desejos que, do fundo do coração e da razão (unidimensional), encontram-se absolutamente entranhados na estrutura pulsional.

Chamo a atenção, mais uma vez, para o fato de que, para a manutenção do processo de acumulação capitalista, o aumento irrefreável da produção e do consumo de bens é condição necessária, acarretando, portanto, uma disseminação sempre crescente da oferta de produtos para estratos cada vez mais variados da sociedade, integrando-os ao estilo de vida (sempre quantitativamente revisto) propagandeado como o ideal a ser atingido para a realização de uma vida feliz. "Enquanto essa constelação for dominante, ela reduz o valor de uso da liberdade; não há motivo para insistir em prol do autodeterminismo quando a vida administrada é a vida confortável e até mesmo "boa",72. A integração depende, além da despolitização praticada constantemente, da crescente afluência que se faz presente na vida pessoal. "Será que ainda faz sentido falar de alienação quando os indivíduos nesta sociedade realmente se encontram a si mesmos nos seus automóveis, aparelhos de televisão, gadgets, jornais e políticos? Este é um mundo de identificação - não são mais objetos mortos que se opõem ao indivíduo como se fossem estranhos" ${ }^{\text {"73 }}$. O trabalhador apenas constituía um sujeito central das esperanças de transformação na medida em que encarnava a negação do capitalismo, enquanto a condição de vida operária negava concretamente a validade da civilização. A assimilação da classe proletária à esfera do consumo ampliado destituiu o trabalhador dessa condição. O que motivaria agora a revolução? "Por que a derrubada da ordem vigente deveria ser uma necessidade vital para aqueles que possuem ou podem esperar por uma casa própria, automóvel, aparelhos de televisão, roupas e alimentos suficientes?"74. A sociedade de consumo sacia os desejos dos homens, livrando-os dos grilhões materiais que cerceavam desde a sua subsistência até uma vida de 'bem-estar'.

Do ponto de vista da totalidade, não é inteligível que a aceitação de tudo o que aí está, desde os programas de televisão constantemente interrompidos por propagandas até a indústria de guerra que leva milhões de pessoas a lutarem e morrerem por motivos que são quase inomináveis e despidos de sentido, ou de fato encontram-se ocultos ${ }^{75}$, seja visto como

\footnotetext{
${ }^{72}$ MARCUSE, Herbert, 2004 [1964a], p. 69 - aspas no original.

${ }^{73}$ MARCUSE, Herbert, 1999 [1965], p. 49.

${ }^{74}$ MARCUSE, Herbert, 1999 [1965], p. 55.

${ }^{75}$ Vejo a enumeração desses problemas que hão de incomodar os sujeitos sociais de nosso mundo como uma espécie de 'contraprova' em relação às críticas recorrentemente feitas à abstração transcendental e até mesmo metafísica que seria levada a cabo pelos teóricos críticos. O descolamento em relação às bases empíricas é uma crítica despida de sentido, ao menos quando tratamos de Marcuse, já que ele insere diversos exemplos objetivos em que vislumbra a comprovação histórica de sua teoria.
} 
uma vida que valha a pena ser vivida sem questionamento ou tentativas de mudar o que se encontra pela frente. A preocupação parte da problemática da aceitação passiva da introjeção de valores que projeta, desse modo, a heteronomia total do indivíduo, na contramão da humanização.

Já abordei o fato do dado fundamental desse diagnóstico da teoria crítica ser a nova configuração das relações entre as classes sociais produzida pela concentração do capital e pela mecanização da produção. Apesar de ainda continuarem presentes, a determinação e a estratificação entre as diversas classes sociais, especialmente com referência à relação com os meios de produção, alteram-se fundamentalmente. Essa é a baliza do processo de integração e conformação em andamento. Diz Marcuse: "Temos portanto, com a crescente mecanização, um crescente isolamento do operariado no interior da própria empresa, o que facilita a integração ao sistema e a despolitização". Desse modo, "a máquina tornou-se antes um elemento de um sistema organizacional que, por sua vez, determina as formas de comportamento do trabalhador, não só dentro de cada empresa, como também em todas as esferas da existência" ${ }^{, 76}$. Pode-se falar, portanto, em uma mecanização do ser social, que se torna cada vez mais parecido a um autômato, negando aquele potencial de individualização existente no período do capitalismo pioneiro. Esse processo decorre da automação industrial, cuja administração do trabalho provoca uma participação positiva e, portanto, com traços de identificação integral entre o trabalhador e essa forma de organização social apesar de, paradoxalmente, tratar-se de um labor não apenas heterônomo, mas sem especificidade alguma, pautado exclusivamente por um processo inteiramente mecanizado.

Essa configuração opõe-se à espécie de treinamento profissional, a educação profissionalizante vigente no período anterior. Mesmo estando longe da formação, no sentido forte do termo, ao menos preparava o indivíduo para exercer uma função particular, que tivesse alguma especificidade caracterizadora, no processo de produção. Ao trabalhador atribuía-se - e ele tinha, portanto - uma profissão (Beruf): ele era aquilo. Dessa identificação é que decorria a possibilidade da negação tal como vislumbrada por Marx. "Decerto, a forma anterior de autonomia 'profissional' do trabalhador era preponderantemente a sua escravização profissional. Mas esse modo específico de escravização era, simultaneamente, a fonte de seu poder específico, profissional, de negação - o poder de deter um processo que o ameaçava de aniquilamento como ser humano. Agora, o trabalhador perde sua autonomia profissional, que o tornava membro de uma classe destacada de outros grupos

76 MARCUSE, Herbert, 1999 [1965], p. 52 - ambas as citações. Sob a mecanização do trabalho, "padronização e rotina igualam atividades produtivas e improdutivas". Id., 2004 [1964a], p. 46. 
ocupacionais, pelo fato de que incorporava a refutação [Widerlegung] da sociedade estabelecida"77. A destruição dessa fonte de negatividade faz com que, desse modo, a atividade constituinte do ser humano, o trabalho como objetificação, e que no capitalismo é tanto alienado quanto alienante, contribua decisivamente para a introjeção da docilidade nos indivíduos.

Essa perda de autonomia far-se-ia presente, de maneira objetiva, no sepultamento das possibilidades de emancipação no modo preconizado por Marx. Enquanto, à época de sua análise, os trabalhadores encontravam-se distantes de compartilhar o modo de vida dominante e, portanto, encarnavam um potencial de protesto, atualmente eles já estão amplamente inseridos em toda a lógica do aparato. É no esteio dessa interpretação que Marcuse aventa o imperativo de uma revolução total, não apenas do modo de produção, mas também dos sentidos, da estrutura pulsional. Afinal, as forças imanentes a essa estrutura "têm efeito também contra a impressão de que a substituição do controle dominante sobre o processo de produção por um 'controle a partir de baixo' anuncia uma mudança qualitativa. Essa impressão era e é válida onde os trabalhadores eram e permanecem a negação viva e a denúncia da sociedade existente. Mas, onde essa classe tornou-se o apoio do estilo de vida dominante, a sua ascensão ao controle acabaria apenas por prolongá-lo"78. Nesse contexto, a manutenção das considerações teóricas que se limitam a repetir a conclusão simplória que concede a primazia à noção da ditadura do proletariado, uma assertiva não mais condizente com a realidade, levam Marcuse a enfatizar a necessidade de outras formas e expressões da prática de resistência e do pensamento negativo, que precisam expor o caráter ideológico da sociedade industrial.

A ampla publicização de um único aspecto que rege os enormes ganhos de produtividade (traduzidos na produção aparentemente ilimitada de bens), em detrimento do reconhecimento do desperdício de recursos numa escala até então inédita (expresso sob o domínio e, conseqüente, estrangulamento da natureza), detém efeitos profundos sobre os fundamentos do ser social. No prefácio político à edição de 1966 de Eros e civilização, Marcuse aborda precisamente esse mecanismo de solapamento da reflexão. "A democracia de massa fornece os apetrechos políticos para efetuar-se essa introjeção do Princípio de Realidade; não só permite às pessoas (até um certo ponto) escolherem seus próprios senhores e amos, e participarem (até um certo ponto) no Governo que as governa, como também permite aos senhores e amos desaparecerem por trás do véu tecnológico do

\footnotetext{
${ }^{77}$ MARCUSE, Herbert, 2004 [1964a], p. 48 - aspas e grifo no original.

${ }^{78}$ MARCUSE, Herbert, 2004 [1964a], p. 263 - aspas no original.
} 
aparelho produtivo e destrutivo que eles controlam, e esconderem o preço humano (e material) dos benefícios e conforto concedidos àqueles que colaboram. O povo, eficientemente manipulado e organizado, é livre: a ignorância e a impotência, a heteronomia introjetada, é o preço de sua liberdade" "79. Trata-se de fatores que jogam a favor da lógica da adaptação, do conformismo e da heteronomia, ao tornarem cada vez mais difícil a tarefa da recusa a esse modo de vida, pintado com as cores vivas e intensas (mesmo que sempre artificiais) da propaganda televisiva e de todo o aparelho da indústria cultural. A vida tecnologicamente organizada da cidade grande é o lugar ideal para o espírito competitivo e destrutivo que fomenta, de maneira nunca dantes vista, o ímpeto da obsolescência planejada.

Como procurei demonstrar, o diagnóstico da integração do trabalhador e, portanto, do chamado equilíbrio de classes, é ininteligível se interpretado somente como fenômeno da esfera do consumo. Ele compreende também e, com o mesmo grau de importância, as relações diretas com a mudança na estrutura socioprodutiva, em virtude de que "a parte crescente de trabalho intelectual e white collar no processo de produção e a crescente produção de serviços (expansão crescente do setor terciário da economia) levaram à incorporação de grandes camadas das classes médias à classe trabalhadora. Essa tendência não se fez presente como 'proletarização'. A aplicação cada vez mais intensiva da técnica e da ciência à produtividade do trabalho havia aumentado bastante o mundo da mercadoria e possibilitado a produção de necessidades sempre novas e de sua (imposta) satisfação. Às custas de um elevado número de sub-privilegiados nos países dependentes desenvolveu-se um padrão de vida relativamente alto para a maioria nas metrópoles. $O$ resultado foi e é: aburguesamento; predomínio de necessidades e aspirações imanentes ao sistema; reprodução do existente pelos dominados sob o crescente e cada vez mais efetivo controle em todas as dimensões da existência, assim como concentração da violência no aparelho de poder dominante" ${ }^{\text {} 80}$. Desse modo, pode-se observar a confirmação das hipóteses levantadas pela teoria crítica marcuseana já em 1941 e que se aprofundaram com o passar do tempo. O aparato de controle e dominação age, portanto, nas duas frentes que, sob os ditames do capital, constituem o ser social: a produção (objetificação alienante do ser na execução do trabalho alienado) e o consumo (reificação não somente das relações produtivas mas, simultaneamente, do ser humano).

\footnotetext{
${ }^{79}$ MARCUSE, Herbert, 1968 [1966], p. 14.

${ }^{80}$ MARCUSE, Herbert, 2004 [1974b], pp. 145 e 146 - aspas no original.
} 
Veja-se como, na esteira da disseminação da racionalidade tecnológica, ocorre uma submissão geral de todas as práticas a esse processo, notadamente no controle sobre as escolhas dos indivíduos. Como argumentado no parágrafo anterior, esse é o modelo de liberdade vigente, o qual se traduz na possibilidade de escolha entre um número predeterminado de ofertas, que se expande para todas as esferas da vida: a escolha do carro, da casa, do sabão em pó, do emprego, dos políticos, do estilo de vida, da personalidade. Trata-se de uma escolha exclusivamente quantitativa: há um elevado número de possibilidades que, entretanto, não constituem alternativas efetivas, pois a todas subjaz a aceitação das regras de uma única lógica de dominação ${ }^{81}$.

Privadas de sua individualidade constituinte, as pessoas tornam-se passivas e conformistas, facilitando a submissão ao aparato. Pode-se observar a recorrente importância da análise dessas formas de controle nos escritos de Marcuse. É, notadamente, a concentração de poder que aparece com mais força, nos momentos em que aponta para o alijamento do pensamento oposicionista dos meios de comunicação de massa, um dos instrumentos de poder mais fortes da sociedade industrial avançada. Afinal, o seu papel na modelagem das instituições democráticas burguesas é fundamental: a eleição representativa está calcada preponderantemente sobre a manipulação dos veículos de propaganda que também impregnam, em alto grau, a educação escolar e a socialização em geral dessa sociedade.

Desde os artigos de crítica da cultura da década de 1930, quando aponta, em Sobre o caráter afirmativo da cultura, o protagonismo socializador dos meios de propaganda de massa no contexto dos regimes totalitários nazista e fascista, essa idéia faz-se presente em seu pensamento. Friso que se torna muito mais evidente em $O$ homem unidimensional, quando efetua a ligação intrínseca com o processo de produção, ao constatar a produção de valor tanto por meio da ciência aplicada quanto do aparato da propaganda. "A sociedade industrial tardia na realidade aumentou (ao invés de diminuir) a necessidade das funções parasitárias e alienadas (para toda a sociedade, mesmo que não para o indivíduo). Propaganda, trabalho público, 'escolarização', desperdício planejado dos produtos não são mais custos adicionais, não-produtivos, mas sim elementos dos custos de produção fundamentais" ${ }^{\prime 2}$.

\footnotetext{
${ }^{81}$ Essa distinção alinha-se à diferenciação entre a razão objetiva e a razão subjetiva, tal como definida por Horkheimer em $O$ eclipse da razão. Cf. HORKHEIMER, Max, 1985 [1946].

${ }^{82}$ MARCUSE, Herbert, 2004 [1964a], p. 69 - aspas no original. Essa formulação está calcada sobre a análise que Marx empreende em $O$ capital, onde salienta as principais balizas do processo de produção do valor. Ali destaca-se a noção ampla do processo de acumulação sob o signo do trabalho coletivo, que recusa, em termos teórico-metodológicos, a sua parcelização e demonstra assim, mais uma vez, a
} 
A noção da disseminação da produção do valor, que está centrada em grau cada vez menor sobre o operário industrial (manual), com o trabalho sendo executado de modo cooperativo, composto por uma gama cada vez mais horizontal de funções, torna-se continuamente mais presente com o desenvolvimento dos meios de produção. Enquanto nos tempos da produção artesanal, da manufatura, pode-se falar somente em trabalho individual, de modo que o trabalho de cada indivíduo, em si, dá origem ao produto final a partir do emprego das matérias-primas, a divisão do trabalho, que se intensifica sob o avanço da revolução industrial, ganha traços ainda mais específicos no esteio do avanço tecnológico, diluindo a separação entre o trabalho manual e o intelectual e projetando, desse modo, uma enorme série de atividades associadas à produção que, apesar de supérfluas para a produção da mercadoria, efetivamente produzem valor nesse novo contexto, tendo em vista que a produção de valor compreende todo o processo de acumulação, o qual não se limita à produção do bem.

Essa fluidez das funções comprova a dinâmica, salientada por Marcuse, da existência de uma relação fundamentalmente nova do trabalhador com o seu labor. Ele realça a importância de ambos os lados que compõem essa transformação: tanto a dimensão da produção quanto a dimensão do consumo foram alteradas em sua relação com o trabalhador. Outrora alijado do consumo dos bens considerados básicos para o sustento, não apenas desfruta agora de todas as benesses que a sociedade tecnológica afluente coloca à disposição, como até mesmo toma parte, de modo objetivo e visível, na disseminação dessa ideologia; é integrado a ela nessa confluência do consumidor e do produtor de mercadorias.

Nesse contexto, destaca-se o modo como "as formas hegemônicas de controle social são tecnológicas em um novo sentido" ${ }^{, 3}$. A tecnologia encontra-se, agora, intrinsecamente relacionada não somente ao progresso tecnocientífico, diretamente ligado ao processo de produção, mas contempla notoriamente a produção do ser social à luz da mecanização cada vez mais generalizada da sociedade. O indivíduo encontra-se enredado tanto no fornecimento quanto no atendimento de seus desejos, um processo que transcorre

importância de uma análise da totalidade. "Um ser humano isolado não é capaz de atuar sobre a natureza sem a participação dos próprios músculos sob o controle do próprio cérebro. Como no sistema da natureza cabeça e mão pertencem um ao outro, o processo de trabalho unifica o trabalho intelectual e o trabalho manual. Mais tarde, ambos separam-se até o limite de uma oposição inimiga. O produto transforma-se, de todo modo, de produto imediato do produtor individual em social, em produto geral do trabalhador coletivo, isto é, de uma equipe de trabalho [Arbeitspersonal] combinada, cujos membros estão mais próximos ou mais distantes do manejo do objeto de trabalho. Com o caráter cooperativo do próprio processo de trabalho alarga-se, necessariamente, o conceito de trabalho produtivo e de seu portador, o trabalhador produtivo. Para trabalhar produtivamente não mais é necessário pôr a mão na massa; basta ser um órgão do trabalhador coletivo, consumar qualquer uma de suas funções subalternas". MARX, Karl, 1968 [1867], p. 531.

${ }^{83}$ MARCUSE, Herbert, 2004 [1964a], p. 29. 
de modo inteiramente heterônomo e que o condiciona a essa forma de relação com o mundo exterior.

A possibilidade de satisfação dessas necessidades imediatas encontra-se submetida às formas de produção que encaram, naquele momento, uma reestruturação em termos da parcela de trabalho humano utilizado no processo de produção. $\mathrm{O}$ descréscimo dessa participação decorre do sempre crescente avanço tecnológico que pauta a industrialização durante o século XX e que acarreta o aumento incessante da automação. "Dei a entender que a automação em expansão é mais do que um crescimento quantitativo da mecanização - que ela é uma mudança no caráter fundamental das forças de produção". [...] A automação parece de fato o grande catalisador da sociedade industrial avançada. Ela é um catalisador explosivo ou não-explosivo na base material da mudança qualitativa, o instrumento técnico da transformação da quantidade em qualidade; pois o processo de automação social expressa a transformação ou, melhor dizendo, a transubstanciação da força de trabalho, em que essa, separada do indivíduo, torna-se um objeto producente, independente e, desse modo, torna-se mesmo um sujeito" ${ }^{\prime 4}$. Desse modo, Marcuse justifica o seu diagnóstico de que está em curso uma alteração na composição orgânica do capital, na relação entre trabalho vivo e trabalho morto, por haver setores em que é possível abdicar quase totalmente do trabalho vivo, e mesmo assim continua havendo produção de valor.

Marcuse identificará essa transformação com as possibilidades de medir a produtividade do trabalho de cada ser humano, no esteio da interpretação histórica de Daniel Bell, também partilhada pelo pensador marxista Harry Braverman. O avanço dessa forma de sociedade industrial dependeu, a partir de um certo momento, notoriamente, do uso da abordagem taylorista para a mensuração detalhada do tempo necessário para a execução das atividades compreendidas na linha de montagem ${ }^{85}$. Esse aparato de mensuração é que configura um elemento central do advento da sociedade administrada no âmbito do processo produtivo. O treinamento específico de engenheiros e técnicos, visando estabelecer as capacidades de levar a cabo essa forma de gerenciar a produção, torna-se uma característica fundamental do capitalismo organizado.

Para Marcuse, é absolutamente fundamental, nesse processo, a função ocupada pela ciência no modo de produção vigente. Ao tornar efetiva, em grau cada vez maior, a sua presença como força produtiva primária, que compõe o núcleo da produção capitalista, o desenvolvimento histórico das relações entre ciência e sistema produtivo manifesta a

\footnotetext{
${ }^{84}$ MARCUSE, Herbert, 2004 [1964a], pp. 55, 56 e 57, respectivamente.

${ }^{85}$ Cf. MARCUSE, Herbert, 2004 [1964a], pp. 47-54 e BRAVERMAN, Harry, 1974, pp. 169-183.
} 
tendência apontada por Marx, no século XIX, quando destacou a conjunção de ciência e tecnologia como componente não somente integrante, mas central, da acumulação do capital. O advento desse processo de, por assim dizer, 'tecnologização' da produção foi tratado por Marx nos termos de que "na medida em que a grande indústria se desenvolve, a criação da verdadeira riqueza torna-se menos dependente do tempo de trabalho e da quantidade de trabalho empregada do que do poder dos agentes postos em movimento durante o tempo de trabalho, poder este que, por sua vez - a sua powerful effectiveness não se encontra em relação alguma com o tempo de trabalho imediato, o qual a sua produção custa, mas depende antes do nível geral da ciência e do progresso da tecnologia, ou da aplicação dessa ciência à produção" ${ }^{\text {"86 }}$. Em tal contexto é que a teoria é retomada por Marcuse, que destaca um outro aspecto qualitativo decorrente desse avanço científicotecnológico.

Trata-se de um sentido não somente técnico, mas que traduz, também, o conteúdo 'político' impregnado no pensamento unidimensional. Essa política não se assemelha, em nada, ao ideal que Marcuse define como a realização de uma democracia socialista efetiva, pautada pela participação coletiva de indivíduos livres e racionais na tomada de decisões, mas expressa, em verdade, a política repressiva que rege o aparato de dominação tecnológico no esteio da ciência instrumental. "A ciência da natureza desenvolve-se sob o a priori tecnológico, que projeta a natureza como um meio potencial, como matéria para o controle e a organização [...] o a priori tecnológico é um a priori político na medida em que a remodelação da natureza tem como conseqüência a remodelação do ser humano e em que as 'criações produzidas pelo ser humano' originam-se de e voltam-se para um todo social" ${ }^{87}$.

Tal ponto diz respeito a uma modalidade relevante da ligação do pensamento marcuseano à importância do avanço técnico para a consecução do reino da liberdade, do modo preconizado por Marx em seus escritos, e que se fez presente de modo mais incisivo na teoria crítica após 1940. "O que é a dialética da libertação com a qual nos preocupamos? É a construção de uma sociedade livre, uma construção que depende do predomínio da necessidade vital de abolir o sistema de servidão estabelecido, e que depende, além disso, e isso é decisivo, do comprometimento vital, consciente assim como subconsciente e inconsciente, com os valores qualitativamente diferentes de uma existência

\footnotetext{
${ }^{86}$ MARX, Karl, 1953 [1857-1858], p. 592. O termo "powerful effectiveness", em inglês no original, pode ser traduzido por "eficácia poderosa" ou "efetividade poderosa".

${ }^{87}$ MARCUSE, Herbert, 2004 [1964a], p. 168 - aspas e grifos no original. Para a famosa polêmica entre Marcuse e Habermas acerca do entendimento da técnica e da ciência como ideologia, cf. HABERMAS, Jürgen, 1969 [1968].
} 
humana livre. Sem a emergência dessas novas necessidades e satisfação, as novas necessidades e satisfação do homem livre, toda mudança nas instituições sociais, não importa o quão ampla, somente substituiria um sistema de servidão por outro sistema de servidão" ${ }^{\text {" }}$. A apreensão do funcionamento dessa dialética é um dado fundamental para que seja elaborada, confirme tratarei no último item de meu texto, a idéia de uma mudança que vai muito além da visão mecanicista em torno de uma alteração no controle do modo de produção. A ampliação da lógica da dominação requer a ampliação da lógica da transformação radical. A mudança emancipatória não pode limitar-se ao controle dos meios de produção, mas tem de atingir a lógica mesma da produção ilimitada de bens e seriços que, paradoxalmente, repõe os pressupostos da escassez: exploração, destruição, competição. De outro modo, a mudança poderia efetuar-se sem interferir, decisivamente, sobre a libertação efetiva do ser humano, continuamente atado à exploração e à submissão, ditames de uma vida repressiva. O embricamento dialético entre ciência e técnica no contexto da liberdade humana tornar-se-á, assim, pano de fundo para a interpretação do sentido da educação.

Harry Braverman, em sua obra-prima Trabalho e capitalismo monopolista, enfatiza precisamente o avanço desse processo de mudança qualitativa preconizado por Marx e tematizado por Marcuse, e situa-o numa periodização similiar: "O contraste entre a ciência como uma propriedade social generalizada, secundária para a produção, e a ciência como propriedade capitalista no centro mesmo da produção, é o contraste entre a Revolução Industrial, que ocupou a última metade do século XVIII e o primeiro terço do século XIX, e a revolução científico-técnica, que começou nas últimas décadas do século XIX e ainda continua em andamento" $"$. A apropriação, sob a forma-mercadoria e de suas regras de funcionamento, do saber racional enquanto saber 'científico', tornou-o uma importante ferramenta de dominação, controle e domesticação, especialmente nos termos da ética produtivista e administrativa. Essa nova dinâmica, que não invalida as etapas que compõem o processo de acumulação, intensifica-se durante o andar do século XX e se expressa na estruturação institucional de um sistema de ensino e pesquisa ${ }^{90}$.

\footnotetext{
${ }^{88}$ MARCUSE, Herbert, 28 jul. 1967, pp. 3 e 4.

${ }^{89}$ BRAVERMAN, Harry, 1974, p. 156.

${ }^{90} \mathrm{O}$ avanço, em termos de grau, da presença da ciência no processo de produção, tanto dos bens materiais quanto da sociedade como um todo, é bastante marcada nos Estados Unidos. A relação desse processo com os esforços de guerra é abordada por Braverman que afirma: "foi somente a partir da Segunda Guerra Mundial que a pesquisa científica nos Estados Unidos, pesadamente financiada pelas corporações e pelo governo e sustentada pelo amplo recrutamento de talentos científicos ao redor do mundo, sistematicamente forneceu o conhecimento científico utilizado pela indústria". BRAVERMAN, Harry, 1974, p. 166.
} 
Uma breve retomada histórica das principais tendências desse processo na institucionalização do sistema de ensino superior nos Estados Unidos, ao longo do século XX, permite especificá-lo melhor e, simultaneamente, apontar certos traços que estão no centro das questões postas pelos movimentos de protesto dos anos 1960 e 1970. 


\section{A institucionalização da universidade moderna nos Estados Unidos}

A concepção da universidade moderna como produtora de conhecimento científico e racional está ancorada na reforma da universidade alemã, implementada ao início do século XIX em Berlim. O ponto central a destacar refere-se ao que Immanuel Kant chamou de o conflito das faculdades ${ }^{91}$. O conflito remete a uma divisão do trabalho que haveria de ocorrer entre as quatro faculdades existentes: a de direito, a de medicina, a de teologia e a recém-criada faculdade de filosofia. A diferença crucial estava na função prática das três primeiras, chamadas faculdades superiores, responsáveis pelo treinamento dos diversos quadros de funcionários necessários à manutenção e ao funcionamento do Estado. Dessa forma, a tutela estatal sobre suas doutrinas era desejável e legítima, visto que se encontravam a serviço do exercício de funções não submetidas ao pensamento, mas aos objetivos de controle das esferas do poder político. Marcadamente diferente era a situação da faculdade de filosofia, responsável por oferecer o espaço ao exercício da razão autônoma e da constituição da ciência na chave do conhecimento racional do mundo. Nesse ideal de razão, a autonomia baseia-se na objetividade dos juízos críticos, vinculando-se a um ideal de liberdade com base no qual Kant recusa qualquer ingerência externa ligada aos objetivos das esferas práticas da vida, referidas, notadamente, ao governo e à religião.

A disputa entre o interesse na autonomia da razão e os interesses sociais de poder no interior da universidade moderna alemã aponta para as tensões históricas que foram internalizadas pela instituição desde a sua fundação. A tensão entre a idéia de universidade como produtora do conhecimento racional, necessariamente crítica das idéias préestabelecidas, e a concepção da instituição como reprodutora da organização social pela qualificação dos indivíduos nos termos necessários para o exercício das funções sociais, expressa-se na diferença de sentido entre Erziehung (educação enquanto inserção do indivíduo no mundo dado) e Bildung (formação).

Com a institucionalização dessa tensão, o assim chamado 'sistema de ensino superior' que, por meio da universidade, espelha a 'configuração' social vigente, foi alçado a outro patamar nessa estrutura. O seu modo de funcionamento reflete a totalidade social, em especial, a reestruturação do trabalho, no contexto do papel de destaque assumido pela ciência como força produtiva durante o século XIX. Na forma teorizada por Marx, o conceito da produção combinada nunca prescindiu do que ele chamou de trabalho

${ }^{91}$ Cf. KANT, Immanuel, 1921 [1798]. 
intelectual, condição necessária para organizar o modo de produção. Num contexto de competição capitalista cada vez mais acirrada que, pouco a pouco, reduz as taxas de lucro nos países 'centrais', observa-se como "no processo de desenvolvimento histórico da produção capitalista, ao chegar à etapa monopolista, manifesta-se, na esfera da produção, um espaço necessário para o trabalho de planejamento, programação e controle, resultante do desenvolvimento científico já alcançado pelas forças produtivas. O trabalho técnicocientífico, agora essencial à produção capitalista, passa a ser determinante e dominante - $e$ momento de mediação necessário à realização do trabalho diretamente produtivo" ${ }^{92}$. $\mathrm{O}$ aparato científico-tecnológico torna-se, em grau cada vez maior, o principal responsável pela produção de valor e, assim, pela manutenção do sistema de dominação. Por um lado, ao propiciar o aumento da mais-valia relativa, que se traduz na produção de valor e, portanto, em condicionante infra-estrutural do modo de produção capitalista. Por outro lado, no nível organizativo, fomentando a mecanização do trabalho ligada à padronização, em variados patamares, da atividade produtiva e social.

O nível de desenvolvimento das forças produtivas e do avanço tecnológico expressa-se no capital fixo, isto é, na quantidade mas, também, na qualidade do trabalho morto objetificado. Um aparato industrial moldado, nos termos de Marx, pelo elevado grau de participação científico-tecnológica traduz o decréscimo da importância relativa do trabalho manual. "O desenvolvimento do capital fixe indica até que grau o conhecimento social geral, knowledge, tornou-se a força produtiva imediata, e que, por conseguinte, as condições do próprio processo de vida social foram colocadas sob o controle do general intellec, e são repostas [umgeschaffen] de acordo com ele" ${ }^{\text {"93 }}$. Desse modo, quando ocorre o desenvolvimento qualitativo do aparato tecnocientífico, proporcionando maneiras mais eficientes de produção, a saber, a produção da mesma quantidade de mercadorias com participação relativa menor tanto da quantidade de matéria-prima quanto do tempo de trabalho, o processo de produção encontra-se cada vez mais dependente do intelecto geral. Conseqüentemente, o trabalho intelectual torna-se supremo tanto na organização quanto na execução do processo de produção.

A ciência passa, assim, a ser reconhecida, de forma objetiva, como a principal força produtiva do modo de produção capitalista. Ela expressa, em si, o ideal de razão introduzido na concepção de mundo do século XIX, e que encontrou sua forma de produção e

\footnotetext{
${ }^{92}$ HIRANO, Sedi, nov. 2001, p. 11 - grifos no original.

${ }^{93}$ MARX, Karl, 1953 [1857-1858], p. 594. Os termos "capital fixe", "knowledge" e "general intellect" aparecem grafados deste modo e neste estilo (sem grifos) e, portanto, em francês, o primeiro, e em inglês, os outros dois, no texto original em língua alemã. Seu sentido, na língua portuguesa, é, respectivamente, "capital fixo", "conhecimento" e "intelecto geral".
} 
reprodução nas instituições de ensino superior. Entretanto, como já indiquei, isso não se dá sem conflitos: como aponta Jacques Verger, “desde sua origem, a corporação universitária não foi uma corporação como as outras; desde seu nascimento ela carregou um certo número de contradições, ligadas, talvez, às necessidades práticas da luta, mas que pesarão em todo o seu desenvolvimento ulterior" ${ }^{\prime 94}$. As contradições marcam o desenvolvimento histórico da institucionalização das disciplinas científicas e filosóficas e da profissionalização do trabalho intelectual.

Max Weber aconselha, em sua palestra de 1917, àqueles que desejam adentrar a vida científica, que se conformem ao fato dela, atualmente, realizar-se em um elevado grau de especialização, o que requer perseverança e abnegação por parte de qualquer interessado em dedicar-se a essa atividade ${ }^{95}$. Assim, seu ditame central é a necessidade absoluta de restringir-se a uma temática e a um enfoque circunscritos, rejeitando aspirações a uma generalização que só poderá levar à mediocridade intelectual.

A interpretação de Weber conceitua essa reorganização em termos do progresso incessante, pois a lógica da produção do conhecimento está ancorada, precisamente, sobre a obsolescência, visto que toda e qualquer descoberta estará, em pouco tempo, ultrapassada pelo avanço da pesquisa. No esteio da disseminação dessa orientação, localizam-se as principais características do que denomina o processo de intelectualização (racionalização) do mundo, isto é, a calculabilidade e a despersonalização e desvalorização das ações e relações sociais: "o progresso científico é uma fração, e a fração mais importante, daquele processo de intelectualização ao qual estamos submetidos há milhares de anos" ${ }^{\text {"9 }}$. A ciência está à frente no processo de deencantamento do mundo que especializa o conhecimento e exige a renúncia da perspectiva geral.

Assim, quando pensa o sentido subjacente à ciência, a qual, como produtora do conhecimento, figura como veículo de formação da racionalidade, rejeita que esteja em jogo a busca de um conhecimento puro e que, acima de tudo, o progresso da ciência leve cada pessoa a ter um conhecimento melhor do modo como 'funciona' o mundo. "A crescente

${ }^{94}$ VERGER, Jacques, 1990 [1973], p. 37. Cf. também CHARLE, Christophe e VERGER, Jacques, 1996 [1994].

${ }^{95}$ Cf. WEBER, Max, 1992 [1917], pp. 80-84.

${ }^{96}$ WEBER, Max, 1992 [1917], p. 86. A expressão da racionalização como degenerescência da formação (Bildung) na Alemanha já era apontada por Friedrich Nietzsche no contexto da disseminação acrítica de uma cultura massificada e que ele, assim como Weber, identificava em sua forma mais acabada com o jornalista, detentor de uma formação pretensamente ampla, mas sem rigor e conteúdo efetivo algum. Como argumenta em um ensaio: "Pelo costume válido aqui, na realidade é exigido algo contrário, ou seja, uma formação curta para assim tornar-se rapidamente um ser que ganhe dinheiro, mas apesar disso uma formação tão rigorosa a ponto de poder tornar-se um ser que ganhe muito dinheiro. É permitido ao ser humano apenas tanta cultura quanto é de interesse do empreendimento". NIETZSCHE, Friedrich, 1988 [1872], p. 668 - grifos no original. 
intelectualização e racionalização não significa, portanto, um crescente conhecimento geral das condições de vida sob as quais nos encontramos. Ela significa, sim, algo diferente: a ciência de que, ou a crença em que, se pudesse adquirir tal conhecimento a qualquer momento, caso se quisesse, ou seja, que, em princípio, não haveria poderes misteriosos e incalculáveis os quais interferissem; que, na verdade, todas as coisas podem em princípio - ser dominadas por meio do cálculo" ${ }^{, 97}$.

Isso nada tem a ver com a compreensão do caminho que leva à natureza, à religião, à arte e ao ser verdadeiros; a ciência não concerne ao "porquê" ou ao "para quê" do empreendimento que é a nossa vida, mas somente ao "como" o mundo é controlável ${ }^{98}$. O sentido da ciência consiste, somente, em oferecer a 'base' de conhecimento (procedimento) que possibilita ao ser humano realizar as ações de seu dia-a-dia, controlando fenômenos fragmentados. Esse sentido dissemina, para o pensamento como um todo, o ideal subjacente às Naturwissenschaften (ciências naturais), desde sempre sem valor positivo que não aqueles da racionalidade cognitivo-instrumental, da lógica interna das leis de funcionamento do mundo natural, exato e calculável. Trata-se de uma razão voltada para a explicação dos fenômenos com o fim de obter o controle sobre eles, visto que "todas as ciências naturais nos dão uma resposta à pergunta: que devemos fazer, se quisermos domínar tecnicamente a vida. Quanto a se de fato devemos e queremos dominá-la tecnicamente, e se isso tem, no fundo e afinal de contas, algum sentido - aquelas ciências nos deixam em suspenso ou adotam pressupostos em relação a seus fins" $" 99$.

Marcuse, em artigo no qual aborda o problema, refaz a história da racionalidade científica instrumental, a partir de Galileu Galilei, enquanto deslocamento das questões científicas do "por quê" para o "como", da qualidade para a quantidade, que ocorreu como condição prévia para o progresso - mas um progresso repressivo, que fomentou não a liberdade, mas a dominação. Foi por essa via que a ciência distinguiu-se das esferas de valor, desligando-se dos fins da ação em um movimento de autonomização que acabou por fortalecer "a relação entre a ciência e a sociedade e incrementou, de modo imensurável, as capacidades instrumentais da ciência na luta pela existência" ${ }^{100}$. Essa pretensão à neutralidade destituiu a ciência de seus aspectos qualitativos de um modo que compromete o exercício da racionalidade crítica face aos resultados de cada investigação.

\footnotetext{
${ }^{97}$ WEBER, Max, 1992 [1917], pp. 86 e 87 - grifos no original.

${ }^{98}$ Cf. WEBER, Max, 1992 [1917], pp. 89-94.

${ }^{99}$ WEBER, Max, 1992 [1917], p. 94 - grifos no original.

${ }^{100}$ MARCUSE, Herbert, 2004 [1965a], p. 130 - aspas no original.
} 
Voltando aos termos de Weber, a relação instrumental com o conhecimento traduzse na relação mercantil do estudante com o professor, notadamente no caso dos Estados Unidos, embora ele afirme que não há dúvida acerca do avanço da "americanização" da universidade alemã ${ }^{101}$. Estão enganados aqueles que vêm ao professor em busca de respostas ao sentido da vida ou visões de mundo (Weltanschauungen) prontas e acabadas; cabe-lhe a tarefa estrita de transmitir, ao aluno, o saber acumulado, pois é essa sua função na divisão do trabalho intelectual, de indivíduo responsável pela disseminação do conhecimento existente, detentor da autoridade legítima sobre os juízos cognitivos (que não são, e nem devem sê-lo, de valor político).

Observa-se, portanto, o desvelar, na análise weberiana, do paradoxo das conseqüências subjacente a esse ideal de investigação racional: enquanto defende a autonomia absoluta do ideal de razão inerente à ciência em face de qualquer valor ou sentido a moldar o mundo, reconhece a subsunção da investigação científica ao processo de racionalização do mundo, ao fim último de dominar a natureza. E é esse ponto que Marcuse tomará como principal molde do empreendimento científico no contexto da racionalidade tecnológica, constituindo o sentido que orienta a prática da ciência e o uso da técnica na sociedade capitalista.

Em artigo sobre a racionalidade em Weber, Marcuse aponta o limite de um pensamento que, capaz de revelar o conteúdo crítico subjacente a essa forma de razão, não se deu conta desse desenvolvimento no interior de sua teoria. Apontou em sua interpretação, de modo correto, a burocracia como o desenvolvimento dessa racionalidade, sem atentar ao tipo de dominação projetado por essa realidade. "Assim, a razão focalizada por Max Weber revela-se como razão técnica: produção e transformação de material (humano e de coisas [dinglich]) por meio do aparato metódico-científico, construído com vistas à eficiência calculável, cuja racionalidade controla e organiza coisas e seres humanos, a fábrica e a burocracia dos funcionários, o trabalho e o lazer" ${ }^{102}$. Apesar de ciente da reificação das

\footnotetext{
101 Para um comentário acerca do anti-intelectualismo nos Estados Unidos em fins do século XIX e começo do XX, pautado pelo predomínio da ética protestante e pelo conflito entre a visão empresarial (business) do self-made man e a intelectual, ligada à educação escolar como propulsora da formação, cf. HOFSTADTER, Richard, 1963, em especial os capítulos IX e X intitulados "Business and intellect" ("Negócios e intelecto") e "Self-help and spiritual technology" ("Auto-ajuda e tecnologia espiritual"), pp. 233-271. Para as raízes anteriores do preconceito face à educação em geral e à formação intelectual em específico baseadas sobre a desvalorização do conhecimento escolar e do professorado de modo amplo, cf. Id., ibid., pp. 299-322.

102 MARCUSE, Herbert, 2004 [1964b], pp. 82 e 83 - grifos no original. A principal questão, para Marcuse, quanto ao paradoxo da teoria de Weber foi, justamente, a sua capacidade de analisar, com tal precisão, o funcionamento do capitalismo, mas tomar, em sua investigação livre de valores (ou livre de pressupostos), essa possibilidade como única e inexeqüível. Desse modo, não pôde compreender que “não a racionalidade técnica, 'puramente' formal, mas a racionalidade da dominação, produz a 'gaiola
} 
relações sociais, notadamente no contexto do mercado, alinhou-se à essa perspectiva e não dispôs dela para apontar um vir a ser qualitativamente diferente.

Mas é, certamente, Weber que expressa o desenvolvimento histórico dominante que se realiza exemplarmente, nos Estados Unidos. Ali, o sistema de ensino superior nasce sob o signo da dissociação do ensino e da pesquisa ${ }^{103}$, diferenciando-se do modelo alemão ${ }^{104}$. Por volta da metade do século XIX, a graduação (sob o nome de undergraduate studies) esteve presente em diversas escolas superiores (colleges ou junior colleges), sem qualquer vínculo com as atividades da pesquisa básica. Um aspecto cultural que definiu o foco prioritário sobre o ensino foi a fraqueza, em especial quando comparado à experiência européia, do nível secundário nos Estados Unidos. O conteúdo ministrado no grau superior era, muitas vezes, aquele que compunha o Gymnasium alemão e os graus equivalentes em França e Inglaterra. Um fator de ordem material que marcadamente estruturou o crescimento quantitativo da educação superior de elite estadunidense foi a condição específica de financiamento: apesar do investimento estatal, uma fatia importante do orçamento das universidades advinha de doações de ex-alunos, formato esse que acabou por ser institucionalizado com a importância das associações de ex-alunos (Alumni $)^{105}$.

No que se refere ao ensino, houve uma primeira fase de crescimento do sistema acadêmico dos Estados Unidos durante o final do século XIX e a primeira metade do século XX. Compreende-se aqui uma expansão tanto em termos do número de instituições quanto de matriculados, com efetiva participação do financiamento privado ${ }^{106}$. Entre os principais motivos do crescimento da população do ensino superior no início do século XIX e após a Primeira Guerra Mundial, temos que "esse foi um periodo de prosperidade nacional ascendente e de renda pessoal crescente. Mais e mais famílias adquiriram os meios de perseguir estratégias educacionais prolongadas para seus filhos. As mudanças na estrutura da economia criaram uma maior demanda por trabalhadores escolarizados, ao mesmo tempo em que as credenciais educacionais eram empregadas mais extensamente como um

de ferro', e que o aprimoramento da razão técnica poderia, muito bem, tornar-se instrumento de libertação humana. Dito de outra forma: a análise de Max Weber do capitalismo não foi livre de valores o suficiente, na medida em que incorporou qualificações específicas do capitalismo às definições 'puras' da racionalidade formal'. MARCUSE, Herbert, 2004 [1964b], pp. 82 e 83 - aspas e grifos no original.

${ }^{103}$ Para o que vem a seguir ver GEIGER, Roger, 1993 e TROW, Martin, 1993.

${ }^{104}$ Cf. TOURAINE, Alain, 1997 [1974], pp. 1-31 e ROTHBLATT, Sheldon, 1993, especialmente pp. 4654 e 56-59. A importância da ligação entre o signo de estar a serviço do progresso civilizacional e o ideal da liberdade acadêmica nos Estados Unidos compreende a produção da visão de mundo (Weltanschauung) estadunidense dita “liberal”. Cf. BEN-DAVID, Joseph e COLLINS, Randall, 1967.

105 Para mais dados envolvendo a relevância tanto dos alumni quanto das fundações privadas (como Carnegie e Rockefeller) para o financiamento da educação e de pesquisa, cf. GEIGER, Roger, 1986, pp. 43-56 e 142-149.

${ }^{106}$ Cf. GEIGER, Roger, 1986, pp. 3-17 e TOURAINE, Alain, 1997 [1974], pp. 59-66. 
critério para a seleção dos empregados"107. Nas décadas de 1920 e 1930, houve uma aceleração no número de matrículas no ensino superior. Tal processo, somado a uma diferenciação qualitativa da oferta de escolas, demarcou o lugar das universidades que viriam, posteriormente, a ser conhecidas como "de pesquisa", restritas, de modo geral, a pequenos círculos da elite, e possibilitou o crescimento e a expansão de diversas instituições até então bastante pequenas (variados tipos de colleges), que cresceram tanto internamente (número de matriculados em cada uma) quanto em seu número total. Essa expansão foi um estágio de preparação fundamental para estruturar os fundamentos da sociedade industrial avançada, tal como pensada por Marcuse, que tem como elemento central a substituição dos operários (blue collar) pelos empregados (white collar) treinados no sistema acadêmico.

Assim como Roger Geiger, Alain Touraine chama a atenção para o fato de que, ainda durante esse período, ocorreu, em virtude do crescimento quantitativo do estudantado, uma mudança na estratificação social dos integrantes do ensino superior, em um processo de integração da classe média. A fase anterior, caracterizada pela produção de uma ordem social, foi pouco a pouco substituída pela reprodução social. Institucionalmente, essa caracterização decorre da complementaridade existente entre universidade e college e, num grau ainda maior, junior college, na organização da totalidade do sistema acadêmico. Desse modo, apresenta-se uma divisão quanto ao tipo de trabalho intelectual para o qual são preparados os estudantes, em uma organização hierárquica no que se refere à educação recebida e às posteriores funções que lhes serão atribuídas na produção. As universidades, notadamente as mais conceituadas (como a Ivy League ${ }^{108}$ ), preparam as elites dirigentes do país, enquanto os colleges e junior colleges preparam os empregados de segundo escalão, estabelecendo uma 'compartimentalização' da educação superior que reproduziu a diferença de oportunidades disponíveis para os negros e as mulheres, já existente no nível secundário $^{109}$.

Christopher Jencks e David Riesman, em sua proposta de interpretação da universidade estadunidense, deslocam o eixo para o que denominam "revolução acadêmica”, a saber, não as alterações nas categorias do sistema de ensino, mas sim a nova relação da instituição com a sociedade ${ }^{110}$. Com esse enfoque, apontam a presença de

${ }^{107}$ GEIGER, Roger, 1986, p. 108. Como destaca Hobsbawm: "Quase tão dramático quanto o declínio e queda do campesinato, e muito mais universal, foi o crescimento de ocupações que exigiam educação secundária e superior". HOBSBAWM, Eric, 2000 [1994], p. 289.

${ }^{108}$ As universidades que compõem a assim chamada Ivy League são as seguintes: Brown, Columbia, Cornell, Dartmouth, Harvard, Princeton, Pensilvânia e Yale.

${ }^{109}$ Cf. TOURAINE, Alain, 1997 [1974], pp. 66-98 e 108-114.

110 Cf. JENCKS, Christopher e RIESMAN, David, 1977 [1968], pp. 1-27. Ao final do livro os autores demonstram também o outro desse desenvolvimento, ao abranger as formas de organização institucional 
faculdades (colleges) nos Estados Unidos desde o século XVII, mas então com um elevado grau de autonomia e descentralização em relação ao Estado ${ }^{111}$. O principal traço interno que deu vazão, na passagem do século XIX para o XX, à nascente importância estrutural da educação superior foi a diferenciação, no contexto da criação de universidades, da pesquisa realizada nas universidades de ponta voltada para o desenvolvimento econômico regional e a produção industrial, em contraposição às atribuições estritamente escolares dos colleges (faculdades 'isoladas' e com infra-estrutura inferior). O início da associação entre a pesquisa acadêmica e os esforços de guerra ocorreu no bojo da Primeira Guerra Mundial, com a parceria entre militares, empresários e pesquisadores universitários, que institucionalizaram a pesquisa guiada por objetivos militares, para a produção de conhecimento de produtos e processos valiosos para o Estado ${ }^{112}$.

$\mathrm{Na}$ esteira da expansão demográfica do estudantado no período, ocorreu um aumento na demanda por docentes habilitados, o que proporcionou o crescimento da 'produção' de doutores em todas as áreas. Apenas nessas condições foi criado, e isso, de início, apenas em algumas instituições, um sistema de pós-graduação, notadamente nas instituições que compõem, hoje, a Ivy League, o grupo de universidades mais prestigiadas e concorridas no sistema de ensino superior dos Estados Unidos. O reflexo dessa pressão de demanda foi um fator importante para a consequiente expansão do sistema de pósgraduação, com o avanço da profissionalização tanto das atribuições docentes quanto da pesquisa, por meio da expansão das graduate schools, responsáveis por conceder os títulos acadêmicos e implementar a pesquisa ${ }^{113}$. A profissionalização fez com que todo juízo científico apenas pudesse ser contestado ou refutado por cientistas da mesma área, a partir de uma base argumentativa que seguisse as regras internas a cada disciplina, não bastando a ausência de reconhecimento público. Isso teve como conseqüência uma mudança também na qualificação e nos condicionantes da docência em nível superior: o doutorado, sinônimo e comprovação da experiência de pesquisa, generalizou-se como requisito para a docência universitária, pois o título concedia a legitimidade necessária em relação à capacidade científica daquela pessoa, que havia sido avaliada por seus pares estando, portanto, apta a

da educação superior que tem como proposta explícita não serem universidades, em especial as faculdades comunitárias (community colleges) e o movimento de educação geral, originado das tradicionais escolas de artes e humanidades (liberal art colleges), que buscam enfatizar exatamente o espaço de uma educação formadora no sentido forte do termo, para além do processo de profissionalização e especialização presente nas universidades e no avanço da pesquisa. Cf. Id., ibid., pp. 480-509.

${ }^{111}$ Cf. também COHEN, Arthur M., 1998, pp. 9-50.

112 Cf. GEIGER, Roger, 1986, pp. 94-107.

${ }^{113}$ Cf. COHEN, Arthur M., pp. 97-174; PARSONS, Talcott, 1968; TOURAINE, Alain, 1997 [1974], pp. 139-171 e WOLFF, Robert Paul, 1991 [1969], pp. 25-54. 
atuar naquela área de conhecimento. Por seu lado, o investimento em pesquisa e desenvolvimento (P\&D) expressa a visão estratégica de privilegiamento da pesquisa aplicada que se torna base da produção na sociedade tecnológica.

A democratização massificada do ensino superior proporcionou um aumento considerável da parcela da força de trabalho detentora, no período posterior a 1935, do diploma de nível superior. Uma parte cada vez maior das ocupações e carreiras exigia esse tipo de formação. Passada a fase inicial de estabelecimento do sistema de pós-graduação e pesquisa (graduate studies e research), no início do século XX, voltou a ocorrer uma estagnação. A situação persistiu até após a Segunda Guerra Mundial, quando a Guerra Fria e a corrida espacial fizeram com que o governo injetasse vultosos investimentos na universidade $^{114}$.

De fato, é nesse período que se localiza, segundo todos os intérpretes, a segunda onda de expansão do século, que levará os estudantes universitários de 1.6 milhão em 1940 para 3.7 milhões em 1960 e 7.8 milhões em $1969^{115}$. Um fator importante no que se refere ao crescimento da população estudantil e sua composição social, foi a promulgação da Lei GI (GI Bill), com o objetivo de facilitar a (re)integração dos ex-combatentes da Segunda Guerra Mundial: "A lei forneceu benefícios a diversos veteranos: um ano de segurodesemprego; cuidados médicos; serviços de aconselhamento; e recursos para matrículas, livros e subsistência enquanto estivessem freqüentando algum programa educacional. Cada veterano tinha direito a um ano de escolarização como estudante em tempo integral, além de um mês a mais para cada mês servido nas forças armadas" ${ }^{116}$. Observa-se, desse modo, a influência exercida pela Segunda Guerra Mundial sobre o crescimento demográfico do estudantado do sistema acadêmico nos Estados Unidos, o que acarretou, em virtude de seu impacto em um curto espaço de tempo, também alterações qualitativas na organização institucional.

Jencks e Riesman indicam que, apesar da expectativa com relação a expansão das possibilidades de acesso ao ensino superior, essas alterações não tiveram grande relevância

${ }^{114}$ Cf. JACOBY, Russell, 2000 [1987], pp. 130 e 131. Também Robert Nisbet marca essa periodização: foi após 1940 e, em especial, após a Segunda Guerra Mundial, que esses financiamentos formaram um novo mecanismo de organização da universidade irresistível à antiga aristocracia professoral - a instituição havia sido imbricada no capitalismo avançado. No mesmo movimento, a ascensão dos administradores detém seu papel na revisão do modo de operação da hierarquia acadêmica. Foi então que a pesquisa ganhou relevância no ensino superior estadunidense vis-à-vis o papel do professor no ensino propriamente dito, com a 'criação' de pesquisadores em tempo integral, despidos de atribuições docentes. Cf. NISBET, Robert Alexander, 1997 [1971], pp. 71-87 e CHOMSKY, Noam, 1969 [1966]. Para uma referência acerca da importância econômica estrutural das grandes guerras no capitalismo recente, cf. BARAN, Paul A. e SWEEZY, Paul Marlor, 1966, cap. 8, em especial pp. 222-244.

${ }_{115}$ Cf. TOURAINE, Alain, 1997 [1974], pp. 115-131 e HOBSBAWM, Eric, 2000 [1994], pp. 290 e 291.

${ }^{116}$ COHEN, Arthur M., 1998, p. 182. Cf. também COTKIN, George, 1997, p. 251. 
em termos de mobilidade social ${ }^{117}$. Isso se deve, preponderantemente, ao elevado grau de hierarquização interna e elitização do ensino superior estadunidense. Por um lado, há as escolas altamente conceituadas, que se restringem às universidades e colleges privados centenários (marcadamente os integrantes da Ivy League) e a algumas universidades e colleges públicos, que limitam o acesso tanto pelas altas taxas de matrícula quanto pelo alto nível do mérito requerido. Há, em contraste, uma vasta quantidade de instituições, tanto privadas quanto públicas, que competem entre si para conseguir estudantes em número suficiente para sua sobrevivência ${ }^{118}$. De todo modo, a generalização da posse do diploma deu vazão a um processo de mudança qualitativa no padrão da atividade exercida pela "nova classe média"119.

Essas mudanças levaram à alteração na organização interna das instituições de ensino superior, que se tornaram empreendimentos capitalistas, aprofundando a relação instrumental com o produto ofertado (o conhecimento na forma do ensino) descrito por Weber, o que requereu o desenvolvimento de um aparato administrativo-burocrático. Para Touraine, duas (entre três) consequências principais apontam para a reconfiguração que vinha acontecendo no âmbito do sistema acadêmico nos Estados Unidos apontam para a centralização da administração. Segundo ele, "ao rejeitar a educação como a sua função principal, o sistema acadêmico torna-se um sistema de produção - produção de diplomas e de conhecimento" ${ }^{120}$. Nesse movimento, o sistema articula-se diretamente ao processo de reprodução social e a universidade tende a perder especificidade institucional e a organizarse de modo empresarial. É o que se expressará exemplarmente nas formulações de Clark Kerr acerca da multiversidade ${ }^{121}$, que substitui a "idéia de universidade" pelos "usos da universidade". A multiversidade caracteriza-se pelo pluralismo de finalidades,

${ }^{117}$ Cf. JENCKS, Christopher e RIESMAN, David, 1977 [1968], pp. 61-154.

${ }^{118}$ Cf. JENCKS, Christopher e RIESMAN, David, 1977 [1968], pp. 257-290. Também Geiger procura matizar o viés democratizador da expansão ao salientar como, entre as universidades de ponta, havia de fato uma elitização do corpo discente e a seleção meritocrática era em boa parte mera aparência. Cf. GEIGER, Roger, 1986, pp. 129-139.

${ }^{119}$ Cf. MILLS, Charles Wright, 1951, pp. 283-289.

${ }^{120}$ Cf. TOURAINE, Alain, 1997 [1974], pp. 255-266 e p. 261.

${ }^{121}$ Cf. KERR, Clark, 1982 [1963]. É aqui necessário fazer um parênteses: tanto em seu prefácio quanto em um capítulo/posfácio de 1972, posteriormente incluído numa nova edição de sua obra, Kerr adverte para o fato de que não se deve confundir, em seu texto, a análise da realidade com a sua defesa. Robert Paul Wolff (1991 [1969], pp. 55-70 e 101-108) procura desmitificar exatamente essa assertiva de Kerr, ao demonstrar como ele não se mantém no nível analítico, mas adentra o laudatório. Complementando tal comentário, pode-se ver tanto no livro de Kerr quanto no de Kenneth Minogue (1981 [1977]) o tipo de escrita que a teoria crítica rejeita: a proposição em fazer uma análise por assim dizer pura. Ao somente reportar-se a fenômenos, sem proceder à sua crítica, há, quer queira, quer não, alguma defesa implícita do processo em questão. 
fragmentação interna e, portanto, centralização administrativa. De fato, nos termos de Kerr, o personagem mais importante do mundo acadêmico é o administrador.

Tem-se, assim, a profissionalização da própria organização institucional da educação superior, na onda do avanço da importância da administração especializada dos estabelecimentos, em detrimento do corporativismo tradicionalmente praticado pelo gerenciamento por parte dos professores. Isso significa que, sob o signo da eficiência e da adaptação às necessidades externas, foi implementada uma cultura empresarial no sistema educacional $^{122}$.

Fundamental no período é, também, o avanço da institucionalização das fronteiras disciplinares, em curso desde a primeira expansão, que representou, segundo Geiger "um dos componentes indispensáveis na modelagem das universidades de pesquisa" ${ }^{123}$. A profissionalização da prática científica em termos de disciplinas especializadas constitui, dessa forma, a organização de amplo aparato de pesquisa, nos moldes da autonomia das áreas do conhecimento. Uma medida burocrática que comprova sua relevância foi a redução, nas grandes universidades, da carga horária dedicada ao ensino, aliada ao uso de doutorandos para ministrar os cursos introdutórios, com vistas à liberação do tempo dos docentes para a pesquisa. Isso demonstra, também, a importância das universidades como loci de pesquisa em face dos institutos de pesquisa "independentes" ${ }^{124}$. Essa estrutura organizativa teve como principal elemento o apoio de fundações à pesquisa, como Rockefeller e Carnegie, para citar as duas mais importantes do período, tanto nas ciências sociais quanto naturais. Os financiamentos ocorriam tendo como destino preponderantemente as próprias universidades ou, eventualmente, institutos de pesquisa diretamente associados a alguma universidade conceituada ${ }^{125}$. É importante notar que havia, por parte das agências financiadoras, uma forte concentração de capital no grupo das universidades "de pesquisa", na tipologia de Geiger.

Russel Jacoby aborda, no processo de profissionalização, a transformação do padrão e do estilo do trabalho intelectual. O desaparecimento do intelectual público e o surgimento do professor universitário, pesquisador especializado, é o resultado do processo de conformação da boemia radical dos anos 1920 aos quadros burocráticos das instituições

\footnotetext{
122 Cf. JENCKS, Christopher e RIESMAN, David, 1977 [1968], pp. 199-256. Esse fenômeno adentrou, com maior facilidade, as escolas de formação profissional no sentido fraco do termo, do conhecimento aplicado, como a engenharia, a administração e a agricultura. Demorou mais nas artes e nas ciências.

${ }^{123}$ GEIGER, Roger, 1986, p. 20. Cf. também GEIGER, Roger, 1986, pp. 1-39.

${ }^{124}$ Cf. GEIGER, Roger, 1986, respectivamente pp. 67-77 e 59-67.

125 Cf. GEIGER, Roger, 1986, pp. 149-167. Um dos frutos desse fomento foi a formação do grupo de pesquisadores que viria a ser conhecido como a Escola de Chicago.
} 
educacionais ${ }^{126}$. "Os intelectuais mais jovens não mais precisam de ou querem um público mais amplo; eles são quase exclusivamente professores. Os campi são como seus lares; os colegas, sua audiência; monografias e jornais especializados, seu meio. Diferentemente dos intelectuais do passado, eles se situam em meio a campos e disciplinas - por boas razões. Seus empregos, suas promoções e seus salários dependem da avaliação de especialistas e essa dependência afeta os temas levantados e a linguagem empregada." ${ }^{127}$.

Essas mudanças levaram a especulações em torno do sentido da existência desse novo profissional, cujo número foi cresceu sensivelmente em virtude da expansão da educação superior nos Estados Unidos. Os extremos variavam entre o diagnóstico do eclipse total do pensamento radical, por um lado, e a criação de uma nova classe, por outro, a qual seria, no contexto da sociedade tecnológica, a nova força de trabalho fundamental ${ }^{128}$.

Um elemento político essencial nesse processo foi a perseguição à subversão, nos anos 1940 e 1950, conforme as diretrizes propostas pelo senador Joseph McCarthy. Jacoby constata que "a quantidade de comunistas e radicais nas universidades é notoriamente difícil de ser estabelecida. Todavia, uma coisa é clara: o macarthismo em seus vários aspectos expurgou ou silenciou com sucesso os radicais acadêmicos"129.

A partir desse quadro amplo, é possível entender as especificidades que moldaram os movimentos contraculturais. A especialização e expansão das disciplinas, a profissionalização dos professores e $\mathrm{o}$ crescimento da universidade situam o desenvolvimento da produção de conhecimento científico e tecnológico nos Estados Unidos pela diferenciação do sistema de ensino superior e sua vinculação social à estrutura de poder tecnocrático e do imperialismo em geral que está sendo desafiada ${ }^{130}$.

126 Cf. JACOBY, Russell, 2000 [1987], pp. 13-53. Para outra fonte acerca da boemia como impulsionadora do 'ethos' do intelectual público, assim como um subsídio à interpretação de Jacoby no que se refere ao declínio intelectual nos Estados Unidos do século XX, cf. o capítulo XV "The intellectual: alienation and conformity" ("O intelectual: alienação e conformação") de HOFSTADTER, Richard, 1963, pp. 393-432. Para uma crítica da abordagem de Jacoby, cf. SAID, Edward Wadie, 1996 [1993], capítulo IV, em especial pp. 69-74.

${ }^{127}$ JACOBY, Russell, 2000 [1987], pp. 6 e 7, respectivamente - aspas no original. "Nos anos 1960 as universidades virutalmente monopolizaram o trabalho intelectual; uma vida intelectual fora dos campi parecia quixotesca. Após a fumaça dissipar, muitos jovens jamais haviam deixado a escola; outros descobriram que não havia outro lugar para ir. Eles se tornaram sociólogos radicais, historiadores marxistas, teóricos feministas, mas não exatamente intelectuais públicos". Id., ibid., p. 8.

${ }^{128}$ Cf. JACOBY, Russell, 2000 [1987], pp. 132-135. Cf. também GOULDNER, Alvin Ward, 1985 1979].

${ }^{129}$ JACOBY, Russell, 2000 [1987], p. 125. Cf. também NISBET, Robert Alexander, 1997 [1971], p. 143. e COHEN, Arthur M., 1998, pp. 212 e 213.

${ }^{130}$ Cf. TOURAINE, Alain, 1997 [1974], p. 183 (ambas citações). Para a visão da crítica conservadora acerca dos protestos e, em especial, de uma reestruturação cogitada nesse âmbito cf. KRISTOL, Irving, 1968. 
De fato, nos Estados Unidos, a dimensão política das questões postas pelos estudantes não se apresenta como algo externo, que se soma posteriormente aos temas propriamente acadêmicos, mas decorre diretamente da experiência no interior das universidades. O Movimento pela liberdade de expressão (Free-Speech Movement), o movimento antiguerra do Vietnã e o movimento negro politizaram a população estudantil, colocando, diretamente, em questão o papel social da universidade e sua inserção no complexo político-industrial-militar ${ }^{131}$. Nas palavras de Paul Rockwell, em documento adotado pela principal organização estudantil dos Estados Unidos, o SDS (Students for a Democratic Society - Estudantes por uma sociedade democrática), como uma carta de declaração conhecida por The Columbia Statement: "Na América, com um orçamento militar de 80 bilhões de dólares, a máquina de guerra é dona das universidades. Ela compra mentes, compra pesquisas, determina o conteúdo das matérias e aloca os meios de comunicação e influência para aquelas pessoas que apóiam a Guerra Fria. A base material da produção intelectual está nas mãos de uma pequena elite" ${ }^{, 132}$.

Também o movimento negro e o movimento feminista equacionaram suas questões no registro das determinações estruturais internalizadas no sistema acadêmico ${ }^{133}$. No movimento negro, por exemplo, uma das controvérsias centrais desenvolveu-se em torno da definição de sua reivindicação entre a demanda pela inserção institucional e pela mudança dos currículos nas universidades existentes ou a criação de uma universidade negra independente. Apesar das diferenças, nos dois casos, o que estava em jogo era o caráter racista do conhecimento científico 'neutro' da civilização moderna. No mesmo sentido, para

${ }^{131}$ Cf. TOURAINE, Alain, 1997 [1974], pp. 173-185; DAVIDSON, Carl, 1971 [1967a] e 1971 [1967b] e BRUSTEIN, Robert, 1971 [1969]. Não se trata, aqui, de reconstruir toda a variedade de aspectos do chamado "movimento de 1968". Para referências a respeito da eclosão dos protestos, cf. BOVENSCHEN, Sylvia, 1998 [1988]; BROSSAT, Alain, 1999; GARCIA, Marco Aurélio, 1999; HAUG, Wolfgang Fritz, 1999. "O ano de 68 recusou cabalmente pertencer ao século XX: criticou a sociedade do espetáculo, a ética do consumo, o urbanismo da alienação em nome da lógica do mercado, da indústria, da ciência e da técnica despoetizadoras. Criticou o cientismo - a adesão à 'ciência em si', atititude que não interroga seus fins, se justos ou desejáveis. Recusou o trabalho alienado, que 'arruina o corpo e martiriza o espírito'; recusou a alienação material e moral. Recusou a política tradicional, a moral tecnocrática, a lógica da hierarquia e da submissão muda; recusou a transcendência do poder e a eficácia de suas leis". MATOS, Olgária Chain Féres, 1998, p. 16 - aspas e grifo no original. Para uma análise do movimento de 1968 no Brasil, cf. CARDOSO, Irene, 2001.

${ }^{132}$ ROCKWELL, Paul, 1971 [12 set. 1968], p. 44. Havia um consenso maior no que se refere ao desejo de redução ou até banimento da indústria de armas de guerra, que incluía também grande parte do corpo docente. Para isso, cf. BELL, Daniel, 1968; FULBRIGHT, J. William, 1971 [18 abr. 1969]; WALD, George, 1971 [4 mar. 1969] e ZINN, Howard, 1971 [1967].

${ }^{133}$ Para as referências às reivindicações e ao contexto de protesto cf. WALLERSTEIN, Immanuel e STARR, Paul, 1971, vol. 1, pp. 293-397. Especificamente para a dissidência interna cf. Id., ibid., pp. 343347 e pp. 365-369. Outra fonte acerca dessas questões encontra-se em TOURAINE, Alain, 1997 [1974], pp. 216-223. 
o movimento feminista, a universidade era parte integrante do sistema patriarcal de discriminação e segregação da mulher em papéis sociais inferiores ${ }^{134}$.

Da perspectiva da universidade como locus da produção científica e intelectual objetiva, imparcial e neutra, as denúncias de seu comprometimento com o poder econômico-militar e as reivindicações de democratização institucional foram interpretadas como um golpe mortal na autonomia acadêmica e intelectual. A "politização da universidade" 135 , apontada pelos professores e administradores acadêmicos liberais e de direita, era, precisamente, a bandeira dos movimentos, que a empunhavam contra o que era, para eles, o direcionamento político-militar da universidade e da produção intelectual e isso, justamente, porque esse compromisso era chamado de autonomia.

Ao longo do século XX, o desenvolvimento do sistema produtivo incorporou a universidade. O processo de internalização institucional das pressões externas, que marca toda a história moderna da instituição, aprofunda-se na sociedade industrial de maneira inédita. Bem sabemos que o movimento estudantil dos anos 1960 nos EUA não se explica sem a referência a importantes questões externas à universidade. Quanto a isso, o motor da mudança de mentalidade está localizado em Berkeley, na Califórnia, nos contexto da caça aos comunistas no âmbito do mccarthismo (anos 1940 e 1950) e da controvérsia da liberdade de expressão ${ }^{136}$ como acontecimentos fundamentais para a conscientização política dos estudantes, caracterizando-se como episódios ligados à vida nacional, mas com claros desdobramentos no interior da instituição em virtude de seu cerceamento das possibilidades e dos modos de fazer pesquisa e lecionar. Trata-se da compreensão, por parte dos próprios intelectuais, das ameaças existentes à sua situação de acadêmicos, envolvendo notadamente a liberdade acadêmica. Ameaças desse gênero alertaram os defensores de um ethos acadêmico para a necessidade de mobilização. Contudo, essa sociedade contra a qual o movimento se põe está, já, inscrita nas próprias finalidades e procedimentos da universidade, de modo a situar os amplos horizontes dos movimentos contraculturais e, assim, seus sentidos emancipatórios possíveis, ponto central do interesse da análise marcuseana, em busca das experiências sociais capazes de gerar negatividade face à unidimensionalidade da sociedade tecnológica.

\footnotetext{
${ }^{134}$ Cf. WALLERSTEIN, Immanuel e STARR, Paul, 1971, vol. 1, p. 397.

${ }^{135}$ Cf. SHILS, Edward, 2001 [1997].

${ }^{136}$ Cf. LIPSET, Seymour Martin e ALTBACH, Philip G., 1967, p. 208.
} 


\section{Possibilidades teóricas e práticas da libertação: a contra-educação para a nova sensibilidade}

\subsection{Os sujeitos da revolução: o marxismo entre a reforma e a revolução}

Havendo explicitado o contexto da transformação estrutural das relações de trabalho e, portanto, das relações de classe a partir do enfoque e da perspectiva da educação superior e do sistema acadêmico como um dos elementos fundamentais desse processo; assim como, em seguida, os principais traços da ampla conjunção de movimentos sociais que marcou as décadas de 1960 e 1970 em diversas partes do mundo capitalista industrial, notoriamente nos Estados Unidos e na Europa, trato agora da interpretação de Marcuse acerca dessa onda de protesto como um vetor importante para, ao menos, afetar a estrutura do sistema dominante e colocar algumas balizas para que sejam pensados modos e formas de praticar a resistência em face de uma sociedade repressiva.

Após manter, durante quase todo o seu percurso intelectual, a reflexão restrita à conceituação de uma crítica radicalmente negativa da sociedade estabelecida, mas sem vislumbrar possibilidades concretas de sua realização, a mudança da realidade empírica, como em qualquer interpretação marxista, teve efeito sobre a sua análise social. "Após décadas de profundo pessimismo politico, ligado às derrotas devastadoras da esquerda, Marcuse viu suas esperanças da revolução socialista revividas no radicalismo da Nova Esquerda. Conseqüentemente, encontra-se uma mudança no tom de seus escritos de meados da década de 1960, que vai de um pessimismo estóico a uma perspectiva mais otimista e utópica. Nesse sentido, a Nova Esquerda rejuvenesceu Marcuse, intensificando e radicalizando o seu pensamento. Na Nova Esquerda, Marcuse encontrou referentes concretos para as suas categorias dialéticas de contradição, negação e grande recusa" ${ }^{137}$.

A composição social, o caráter e o alcance dos movimentos sociais que emergem nos anos 1960 puseram novas questões para a interpretação sociológica e política. Uma das mais fundamentais é, por certo, a questão do sujeito: a análise do sentido e do potencial político de sua prática. Marcuse destaca-se entre aqueles que argumentaram a favor do caráter emancipatório e transformador do movimento, contudo é possível indicar algumas

${ }^{137}$ KELLNER, Douglas, 1984, p. 300. 
oscilações que revelam pontos de tensão teórica em seu diálogo crítico com a interpretação marxista.

A questão que envolve a por assim dizer 'definição' explícita e rigorosa daqueles que haveriam de ser os sujeitos responsáveis por levar a cabo a revolução chegou a ser classificada por Marcuse como uma falsa questão. No que se refere especificamente à sociedade industrial avançada, destacava, como mencionado acima, a inexistência de uma classe que figurasse como a oposição absoluta, tanto pelas suas atitudes quanto pela sua posição no processo de produção. Ou seja, diferentemente da maneira pela qual Marx explorou esse ponto, mesmo que somente em algumas indicações, ao remeter à consciência de classe como um elemento central da articulação do protesto, por tratar-se de indivíduos em condições estruturais parecidas e que, conseqüentemente, teriam uma visão e uma experiência em algum grau semelhantes da exploração, atualmente a negação está desvinculada de uma única classe e encontra expressão em indivíduos ou grupos isolados. Por vezes, Marcuse atribuiu a designação de "marginais" aos integrantes de tais grupos, em virtude da bandeira levantada por eles fazer referência a alguma forma de exclusão. Eles são considerados isolados em decorrência de suas diferentes características formativas e de sua posição na estrutura da sociedade; o ponto comum é precisamente a oposição a diversos dos elementos positivos vistos como a base da forma de dominação, como procurei expor ao referir-me concisamente, no sub-item anterior, a esses movimentos.

Como está em jogo a possibilidade de erigir uma sociedade diferente da existente, é necessário poder discernir, no interior da história vigente, aspirações, teorias e práticas que busquem a efetivação de uma outra realidade. O debate sob a orientação marxista, notadamente do marxismo-leninismo, sempre manteve sua ligação com a importância da classe trabalhadora para a consecução dessas possibilidades. Questionando a 'supremacia' dessa orientação, Marcuse torna mais explícita a relação com o marxismo, tal como preconizado por Lukács e Korsch, sendo esse um dos motivos fundamentais da tensão teórica do pensamento marcuseano.

O norte que dá vida ao pensamento de Marx refere-se, para esses autores e, por conseguinte, para Marcuse, ao método, ao modo de fazer a crítica da sociedade existente, buscando apontar os elementos que demonstram as possibilidades de mudança. E pode-se localizar nesse modo de abordagem a importância concedida à teoria como o ponto de partida para duas formas de prática: tanto a crítica à sociedade presente quanto a organização que rege as formas de protesto. 
O debate pautar-se-á, notadamente, pela concepção de marxismo a que já foi feito referência no primeiro item de meu trabalho. No momento em que Lukács põe essa vertente da discussão acerca do marxismo em uma de suas grandes obras, História e Consciência de Classe, a questão gira justamente em torno de uma das teses fundamentais recorrentemente apresentadas por Marcuse: a distância entre a prática do materialismo histórico-dialético, por um lado, e o agarrar-se de maneira impreterível, ponto a ponto, ao diagnóstico de mundo apresentado por Marx em suas obras. Qual o problema encontrado nessa segunda opção? O defrontar-se com as alterações históricas que transformam o nosso entorno e que, em virtude disso, tornam inválidas certas categorias e formulações que dizem respeito à interpretação da estrutura social. Nesse contexto é afirmado: "Suponhamos, pois, mesmo sem admitir, que a investigação contemporânea tenha provado a inexatidão prática de cada afirmação de Marx. Um marxista 'ortodoxo' sério poderia reconhecer incondicionalmente todos esses novos resultados, rejeitar todas as teses particulares de Marx, sem, no entanto, ser obrigado, por um único instante, a renunciar à sua ortodoxia marxista. O marxismo ortodoxo não significa, portanto, um reconhecimento sem crítica dos resultados da investigação de Marx, não significa uma 'fé' numa ou noutra tese, nem a exegese de um livro 'sagrado'. Em matéria de marxismo, a ortodoxia se refere antes e exclusivamente ao método" ${ }^{138}$. Desse modo, o cerne concentra-se sobre o embasamento da análise concreta da estrutura e dos processos sociais por meio do materialismo históricodialético. O que é condenável é ater-se a categorias empiricamente negadas apenas por estarem descritas numa primeira interpretação do mundo fornecida por Marx em seu tempo.

Por método entenda-se o materialismo histórico-dialético que é constituído da análise crítica da realidade e de suas condições materiais visando criticar os aspectos regressivos que a integram e, portanto, desvelar as relações encobertas por um véu ideológico, proporcionando o primeiro passo para uma transformação social. Esquivar-se, por conseguinte, de reificar a teoria ao repetir incondicionalmente, como se fossem palavras de ordem, análises que faziam sentido no momento histórico com o qual Marx se defrontou,

${ }^{138}$ LUKÁCS, Georg, 2003 [1919], p. 64 - aspas e grifo no original. Em um de seus primeiros artigos, ainda na década de 1920, Marcuse faz a seguinte referência: "O marxismo é a teoria da revolução proletária e a crítica revolucionária da sociedade burguesa; ele é ciência na medida em que a ação revolucionária, que ele procura libertar e assegurar, requer a visada [Einsicht] em sua necessidade histórica: na verdade de sua existência. Ele vive na unidade indissolúvel de teoria e prática, ciência e atividade, e qualquer investigação marxista precisa conservar essa unidade como fio condutor supremo. Ela erra de antemão o seu objeto quando procura testar a consistência [Geschlossenheit] lógica, a coerência universal, a validade intemporal do marxismo de algum lugar que lhe é transcendente. As verdades do marxismo não são verdades do conhecimento, mas do acontecimento". MARCUSE, Herbert, 2004 [1928], p. 347. Numa palestra de 1966 ele recoloca a distinção entre o que está escrito e, portanto, não pode ser alterado (a análise histórica realizada) e o método (o pensamento negativo) de Marx, definindo o sentido eminentemente histórico da negação. Cf. MARCUSE, Herbert, 2004 [1966b]. 
é o objetivo principal de Marcuse. É desse modo que, como decorrência de estar face a uma situação de revolta que, como enfatiza diversas vezes, direciona-se contra uma sociedade 'democrática' e em bom funcionamento, aponta para aqueles que podem, eventualmente, vir a ser uma das forças dessa transformação.

Tendo isso em vista, o que é por ele advogado como um absolutamente necessário reexame passa pelo questionamento de duas teses que foram elevadas a 'postulados' ou 'axiomas' no pensamento marxista dogmático ${ }^{139}$ : (a) a revolução é a tomada violenta do poder do Estado pela classe operária organizada em partido, instituindo a ditadura do proletariado para destruir as relações de produção baseadas na propriedade privada dos meios de produção; (b) o sujeito da revolução socialista é o proletariado. Definido pela ausência da propriedade privada, ele é a negação determinada da ordem burguesa que, como toda classe social revolucionária, projetará sua própria condição como princípio da nova sociedade.

A base empírica sobre a qual Marcuse se apóia para o novo diagnóstico está ligada à forma de organização do poder, que partilha do controle das instituições centrais nas mãos de poucos grupos, que se encontram, portanto, extremamente concentrados mas com um alto grau de descentralização espacial. Tem-se aqui tanto o poder econômico, sob a forma das maiores e mais lucrativas empresas, dos controles sobre o câmbio de diferentes países e sobre recursos naturais essenciais como o petróleo, até o poder puramente militar concentrado nos exércitos nacionais. Estando os exércitos submetidos aos chefes de Estado, e com a legitimação da democracia representativa calcada na governança dos parlamentares, está construída uma ponte quase que direta entre os poderes econômico e militar: a conjunção de lobbies e financiamentos que apóiam interesses escusos (vested interests) é o impulso básico para a eleição de parlamentares, as figuras que encarnam o sistema de dominação. Esse encadeamento do poder e a elevada capacidade de organização levam Marcuse a afirmar: "Uma coisa podemos seguramente dizer: que a idéia tradicional de revolução e a estratégia tradicional de revolução estão fora de moda, simplesmente ultrapassadas pelo desenvolvimento de nossa sociedade" [...] "A idéia de que um dia ou uma noite uma organização de massa ou um partido de massas de qualquer espécie marchem sobre Washington e ocupem o Pentágono e a Casa Branca e organizem um governo, considero-a completamente fantástica e sem qualquer correspondência com a

\footnotetext{
139 "O reexame da teoria marxista é uma das mais urgentes taarefas para se compreender a situação contemporânea. Talvez nenhuma outra teoria tenha tão corretamente antecipado as tendências básicas da sociedade industrial tardia - e aparentemente tirado conclusões tão incorretas dessas análises". MARCUSE, Herbert, s.d. [1957], p. 1.
} 
realidade [...] Temos de nos desacostumar desta idéia de revolução" ${ }^{\text {140 }}$. O processo precisa dar-se exatamente de modo contrário, disseminado em várias frentes de ação, ao mesmo tempo que projeta uma visão crítica da totalidade do aparato tecnológico de dominação.

Da mesma forma como o modelo de revolução outrora tanto almejado quanto realizado já não é mais o mesmo, também o móvel do protesto alterou-se qualitativamente. Marx trata longa e detidamente, em $O$ capital, das condições sub-humanas a que se encontravam submetidos os trabalhadores das fábricas inglesas, sob maus-tratos e altíssimo grau de exploração, por assim dizer, objetivamente perceptíveis. Diferentemente, a sociedade industrial avançada reproduz-se sob a aparência da benesse, da fruição do lazer (e não do tempo livre, de acordo com a distinção feita em $O$ homem unidimensional), dos bens de consumo, de um grau de produção material jamais visto. Trata-se, em suma, da aparente realização do melhor dos mundos, exatamente como veiculado na propaganda. Nesse contexto, também a revolta face à truculência dessa realidade ganha uma outra roupagem. "De modo completamente diferente da revolução de períodos históricos anteriores, essa oposição direciona-se contra a totalidade de uma sociedade em bom funcionamento, próspera - um protesto contra a sua forma, a forma-mercadoria de seres humanos e coisas, contra a imputação de falsos valores e de uma falsa moral. Essa nova consciência e a rebelião pulsional isolam esses oponentes das massas e da maior parte dos trabalhadores organizados, da maioria integrada, e provocam a concentração das práticas políticas radicais em minorias ativas, predominantemente na intelligentsia burguesa jovem e na população dos guetos. Antes de qualquer estratégia e organização política, a libertação torna-se uma necessidade "vital""141. Ao ir além do véu ideológico da aparência imediata de uma beleza estética benéfica, ao expor as contradições que se apresentam diariamente tanto nos países da metrópole quanto na periferia do capitalismo, os movimentos subversivos justificam o despertar de uma esperança rumo a uma eventual transformação futura da realidade vigente. Afinal, o inconformismo e a revolta perante uma sociedade que, a todo o momento e aos olhos de todos, desqualifica amplas parcelas de sua população deve ser uma reação natural, o que quer dizer, a projeção de uma estrutura pulsional humana que compreende a busca do prazer e da felicidade, e não a submissão à violência e ao ódio. Já esse mesmo sentimento de repulsa em face de um aparato de dominação que procura, em seu discurso, inverter, falsificar e minimizar os malefícios necessários ao seu sustento requer a adoção de uma visão do funcionamento da totalidade social.

\footnotetext{
${ }^{140}$ MARCUSE, Herbert, 1999 [1968], p. 67 e 1999 [1972].

${ }^{141}$ MARCUSE, Herbert, 2004 [1969], pp. 283 e 284 - aspas no original.
} 
O modo de colocar em ação essa tomada de posição está pautado pelo questionamento do princípio de realidade vigente, o princípio de desempenho. Ele engloba, entre outras características, a relação de dominação do ser humano sobre a natureza, de uma exploração dos recursos cuja forma projetou, também, o modo da sociabilidade praticada sob o capitalismo concorrencial: o atiçamento a uma competição incessante entre os indivíduos pela comprovação do desempenho superior, pela demonstração de que se é o melhor em tudo, seja no trabalho, na escola, no jogo de futebol, no sexo. O caminho para vencer essa corrida insiste na submissão da natureza aos desejos e às necessidades mais absurdos da sociedade.

Nesse sentido, já em artigo de 1932, quando Marcuse trata da teoria de Marx como delineada nos Manuscritos econômico-filosóficos, faz-se presente o pensar da vida humana como a aquisição da propriedade de sujeito necessariamente em mediação com a natureza que o rodeia. "Toda a 'natureza' é mediadora da vida humana, 'meio de vida' do ser humano; ela é toda a sua condição [Voraussetzung], que ele deve incorporar e recolocar em sua atividade. $O$ ser humano não pode simplesmente aceitar o mundo material ou satisfazer-se com ele; ele precisa apropriar-se dele; ele precisa, por assim dizer, repor os objetos desse mundo em órgãos de sua vida, a qual se leva a efeito por eles e neles"142. A questão é a da superação de uma restrição imposta aos seres humanos: a de que o processo decisório acerca do projeto de organização da totalidade social, que incorpora a vida em meio à natureza, não é social, mas particularmente definido. A necessidade de refletir acerca dessa relação deve estar presente na perspectiva dos indivíduos e grupos que se propuserem a buscar a emancipação, pois repensar essas balizas perpassa os primeiros passos para a negação do sistema estabelecido.

\footnotetext{
142 “Die ganze 'Natur' ist Medium des menschlichen Lebens, 'Lebens-mittel' des Menschen; sie ist seine Voraussetzung, die er aufnehmen und in seiner Tätigkeit wieder setzen muß. Der Mensch kann die gegenständliche Welt nicht einfach hinnehmen oder sich nur mit ihr abfinden; er mu $\beta$ sie sich aneignen; er тиß die Gegenstände dieser Welt gleichsam zu Organen seines Lebens, das sich in und durch sie auswirkt, umschaffen". MARCUSE, Herbert, 2004 [1932], p. 522 - aspas e grifo no original. Essa passagem coloca alguns problemas de compreensão e, mais ainda, de tradução. Primeiramente, vale esclarecer o termo "Lebensmittel" (sem hífen): na língua alemã corrente ele é sinônimo de "alimento", sendo um substantivo originariamente composto de "mittel", "meios", e "Lebens", "de vida". Dessa forma, no jogo de palavras que vemos aqui feito, não se trata de uma proposição para instrumentalizar a natureza como meio de vida para o ser humano, o que não faria sentido algum tendo em vista o restante da obra de Marcuse, mas sim demonstrar como o ser humano vive, necessariamente, 'em meio à' natureza, com base nela. Além disso, ao final da citação, não fica claro se a sua vida se leva a efeito por e no mundo material ou por e nos objetos desse mundo, já que a declinação de ambos no alemão remete ao mesmo artigo e à mesma terminação, não possibilitando a distinção. Finalmente, a palavra "umschaffen" é de raríssimo uso em alemão, e eu optei por traduzi-la como "repor", já que o prefixo "um" diz respeito a uma "alteração" ou "inversão" de sentido, e o verbo "schaffen" tem uma ampla gama de significados em torno de "fazer" e "criar", o que, na terminologia marxista da língua portuguesa, foi adotado como "por".
} 
Essa configuração espelha-se na conceituação de Marcuse. Assim como em outras noções (romantismo, utopia), ele desdobra a noção de progresso em dois, conceito e contraconceito: ao "conceito quantitativo de progresso podemos chamar de progresso técnico e podemos opor-lhe o conceito qualitativo de progresso, tal como foi elaborado sobretudo na filosofia idealista e talvez de maneira decisiva por Hegel. Aqui o progresso na história consiste na realização da liberdade humana, da moralidade: um número cada vez maior de seres humanos torna-se livre e a própria consciência da liberdade incita a uma ampliação do âmbito da liberdade. $O$ resultado do progresso aqui consiste na humanização progressiva dos homens, no desaparecimento da escravidão, do arbítrio, da opressão e do sofrimento. Podemos chamar humanitário [humanitären] a esse conceito qualitativo de progresso" ${ }^{143}$. Sob esse prisma é recorrente, nos escritos marcuseanos, a importância concedida às idéias progressistas, opostas à repressão, ao conformismo ou ao conservadorismo. E é essa idéia de progresso, como busca e expressão da felicidade humana, que deve estar no horizonte do discurso da emancipação.

As revoltas e os protestos realizados pela juventude nos Estados Unidos, pela assim chamada Nova Esquerda (muito além do movimento estudantil), traduziam, em condições diversas, questionamentos dessa espécie. Resistiam aos processos de introjeção dos mecanismos da indústria cultural; rejeitavam o estilo de vida que proclamava a felicidade como o infindável acúmulo de bens de consumo; recusavam a promessa de uma felicidade repressiva. Para além disso, rejeitavam também as lideranças estabelecidas, que forneciam respostas e linhas de ativismo prontas. "Essa oposição é livre de ideologia ou mesmo permeada por extrema desconfiança em face de toda ideologia (até mesmo da socialista); ela é, a um só tempo, rebelião sexual, moral, intelectual e política" ${ }^{144}$. Vejo como um dos componentes fundamentais da atração exercida pelos movimentos sobre a (des)esperança marcuseana precisamente esse questionamento do princípio da civilização tecnológica, que implicava, em algum grau, a sua noção da revolução total. Não apenas efetuavam a crítica teórica, o debate dos problemas inerentes a essa sociedade, como também organizavam a prática política coletiva, provocando a disseminação dessas idéias e agindo, assim, num sentido de conscientização crítica.

\footnotetext{
${ }^{143}$ MARCUSE, Herbert, 2001 [1968], p. 112 - grifos no original.

${ }^{144}$ MARCUSE, Herbert, 1998 [1967a], p. 236. Quando se dirigia ao público estadunidense mais variado, como nessa fala em homenagem ao semanário "Guardian", procurava reforçar esse aspecto: "acredito que a Nova Esquerda é a única esperança que temos hoje. A sua tarefa é preparar a si e aos outros, não esperar, mas sim preparar-se moral e politicamente, hoje, ontem e amanhã, pela teoria e pela prática, para o tempo quando os crescentes conflitos do capitalismo corporativo tiverem perdido a sua união repressiva e abrirem-se novos espaços, nos quais se pode dar início ao verdadeiro trabalho do socialismo livre”. MARCUSE, Herbert, 1998 [1968d], p. 498.
} 
Desse modo, sustenta Marcuse que, em qualquer período histórico, as forças subversivas estão representadas por aqueles que praticam a crítica da realidade posta, tendo em vista a defesa da liberdade e da felicidade individual. São a teoria e a prática hic et nunc, de acordo com a proposição de uma vida de menos labuta, que distinguem essa posição de resistência. Ao enfrentar, mais uma vez, o problema que lhe é colocado numa entrevista quanto ao caminho que leva à sociedade emancipada, diz Marcuse: "É, obviamente, a pergunta acerca do sujeito da transformação: quem é o sujeito da revolução? Esta pergunta não me parece razoável [unvernünftig], pois o sujeito da revolução somente pode desenvolver-se em meio ao processo de transformação. Não é uma coisa que simplesmente exista e que somente precisa ser encontrado em algum lugar. O sujeito da revolução nasce com a prática, com o desenvolvimento da consciência e o desenvolvimento da ação" ${ }^{\prime 45}$. Vem à tona, novamente, uma das pedras de toque angular do pensamento marxista: a idéia de movimento, que rejeita a rigidez ou fixidez dos conceitos sob a ótica dialética, não se deixando enredar em um determinismo estéril.

Determinar, a priori, os sujeitos da transformação social não faz sentido. Essa espécie de 'resolução' de grande parte do discurso autodenominado de marxista, baseia-se sobre a assertiva de que ainda não se está em meio a um processo revolucionário e que, em virtude disso, é impossível apontá-los. Isso vale em especial do ponto de vista teórico, da crítica dialética da sociedade: buscá-los nesse contexto marcaria somente um trabalho de adivinhação, essencialmente a-histórico, para aqueles que aleatoriamente procurassem por alguma solução, ou uma reificação da teoria, para aqueles que insistissem num pseudomarxismo ao aterem-se àqueles operários industriais que não mais se encontram sob as mesmas condições descritas por Marx. Nesse contexto, numa palestra de 1968, Marcuse propõe-se a tratar, preliminarmente, de uma forma de conceituação eminentemente teóricometodológica. "Quero fornecer uma definição muito provisória do sujeito revolucionário quando digo: é aquela classe ou aquele grupo para quem, em virtude de sua função ou colocação na sociedade, a revolução é uma necessidade vital e que é capaz de arriscar tanto o que lhe pertence, quanto o que pode alcançar no interior do sistema estabelecido, para tomar o lugar desse sistema - uma mudança radical, que de fato incluiria destruição, a saber, a eliminação do sistema existente. Repito: a revolução tem de ser uma necessidade

\footnotetext{
${ }^{145}$ MARCUSE, Herbert e POPPER, Karl, 1971, pp. 15 e 16. Dois anos antes já havia feito o mesmo juízo acerca deste problema: "A procura pelos portadores históricos específicos da transformação revolucionária nos países de capitalismo avançado é de fato sem sentido. As forças revolucionárias emergem desse próprio processo de transformação; a tradução do potencial em atual é o trabalho da prática". MARCUSE, Herbert, 2004 [1969], p. 307.
} 
vital para uma tal classe ou grupo, que tem de ao menos ser capaz de iniciar uma revolução, quando não até mesmo de realizá-la"146.

Decorre desse diagóstico que, para Marcuse, não se deve rejeitar a importância dos movimentos, mesmo que, num prisma imediato da análise marxista, componham alguma classe intermediária ou até mesmo a classe burguesa da sociedade. É necessário saber se sua prática é crítica, se está comprometida com a mudança social radical e se, portanto, incorpora o valor de combater o princípio de realidade vigente e buscar, assim, novos horizontes históricos. Há clareza nesse ponto: esses indivíduos não precisam ser os responsáveis pela revolução, já que constituem oposição crítica ao, mas não negação concreta do, sistema de dominação.

A tensão apresenta-se quando o autor aponta para o fato de que as classes trabalhadoras, mesmo existentes em número muito mais reduzido, ainda detêm um papel preponderante quando a revolução estiver em curso. Tal noção está fundada sobre outro pressuposto básico: a revolução precisa, necessariamente, ser feita pela maioria, já que se trata de um confronto ostensivo ${ }^{147}$. Somente quando houver amplas parcelas da população organizadas para enfrentar o poder estabelecido, pode-se vislumbrar a possibilidade de uma transformação social radical.

Para Marcuse, o problema da integração da classe trabalhadora obriga a vê-la como uma classe revolucionária em si, entretanto, de forma alguma, para si, remetendo aos padrões de consumo e de conformidade. O entrave básico é precisamente o da consciência: eles ainda constituem, em alguma medida, uma oposição em virtude da posição no processo de produção (objetivamente), mas estão longe de sê-la subjetivamente. Dado o novo estilo de vida, pelo qual introjeta as falsas necessidades da sociedade de consumo, o proletariado

\footnotetext{
${ }^{146}$ MARCUSE, Herbert, 1998 [1968b], p. 453. Kellner vê o modo pelo qual Marcuse mantém-se atado à procura pelo sujeito como um dos principais entraves ao desenvolvimento da teoria social radical. A meu ver, nessa crítica ele parece subestimar o objetivo marcuseano em tornar o sujeito revolucionário cada vez mais 'horizontalmente' determinado, cruzando, em termos de origem econômico-social, diversos estratos, camadas e grupos. Cf. KELLNER, Douglas, 1984, p. 316. A "tendência" que Marcuse procura enfatizar é aquela da oposição radical ao sistema de produção e de necessidades estabelecido. Desse modo, discordo da conclusão de Kellner de que o sujeito revolucionário foi um fantasma que assombrou o projeto de Marcuse. Cf. Id., ibid., p. 318.

147 Apesar de não solucionar o modo como se poderia chegar a esse ponto, Marcuse é enfático ao expressar a necessidade de um movimento de massas, no sentido de abranger uma grande parte da população: "Quando utilizamos esse conceito de sujeito revolucionário precisamos dizer que uma revolução sem a classe trabalhadora industrial ainda é inimaginável. Não consigo imaginar um Estado tecnicamente avançado em que uma revolução possa ser levada a cabo sem o proletariado industrial" e "O movimento estudantil não é, apesar de revolucionário em sua teoria, em suas necessidades pulsionais e em seus fins, uma força revolucionária, talvez nem mesmo uma vanguarda, enquanto não houver massas capazes de e dispostas a filiar-se a ele". Respectivamente MARCUSE, Herbert, 1998 [1968b], p. 453 e MARCUSE, Herbert, 2004 [1969], p. 291.
} 
"não aparece mais como a contradição viva da sociedade existente"148. Tendo apontado a domesticação do proletariado pela organização burocrática da civilização tecnológica, Marcuse identifica, claramente, a emergência da perspectiva negativa nos movimentos da juventude universitária. Emergem outros grupos que adquirem importância nesse processo, pois estão conscientes do modo como se dá a exploração e manifestando-se por mudanças. "Acredito que a intelligentsia estudantil represente hoje um tal grupo, não imediatamente como poder revolucionário mas, como eu dizia anteriormente, um 'détonateur', um catalisador, uma minoria militante [...]. Essa intelligentsia estudantil é potencialmente um grupo revolucionário, pois das fileiras desse grupo é que o capitalismo recruta os futuros quadros para a esfera de produção, os seus técnicos, cientistas, engenheiros, matemáticos, até mesmo sociólogos e psicólogos e talvez até mesmo filósofos! Esse grupo assumirá, por conseguinte, de modo cada vez mais forte, uma função central no processo de produção" ${ }^{149}$. Vê-se como a relação com a infra-estrutura ainda é um elemento determinante, já que o potencial da ação advém da importância de sua atividade para a ordem produtiva.

Desse modo, para Marcuse, a Nova Esquerda voltou a colocar a revolução no horizonte de possibilidades contemporâneo nos países de industrialização avançada. E é essa particularidade que, a seu ver, não somente o autoriza a vê-la como o principal motor de uma revolta, mas sim como o seu fator per se, em virtude da abnegação daqueles que, em decorrência de sua posição no processo de produção permanecem classe revolucionária em si (objetivamente), mas estão distantes de serem-na para si (subjetivamente) ${ }^{150}$. "A Nova Esquerda foi um desencadeador decisivo da mudança atualmente em curso. A ativação das minorias negras e marrons, a oposição disseminada que revelou a política dos crimes de guerra na Indochina, o conflito entre os principais meios de comunicação de massa e o governo - todos esses sucessos nos Estados Unidos devem-se, preponderantemente, aos

${ }^{148}$ MARCUSE, Herbert, 2004 [1964a], p. 52. "Em vista do crescente peso do contingente de empregados [Angestelltenelements] nesse processo, a radicalização política teria de estar acompanhada da emergência da consciência e da ação independentes dentre os grupos de empregados - um desenvolvimento bastante improvável na sociedade industrial avançada". Id., ibid., p. 58.

${ }^{149}$ MARCUSE, Herbert, 1998 [1968b], p. 454 - aspas no original. Como se sabe, Marcuse enfatiza o caráter crítico e emancipatório do movimento contra interpretações divergentes, que apontavam, principalmente, as ambigüidades e as dimensões regressivas das práticas estudantis nos Estados Unidos e na Europa como, por exemplo, Claude Lefort, cf. LEFORT, Claude, 1999 [1979], em especial p. 218. A referência central é, por certo, o debate com Theodor Adorno. Cf. ADORNO, Theodor W. e MARCUSE, Herbert, 1997 [1967-1969] e ADORNO, Theodor W., HORKHEIMER, Max e MARCUSE, Herbert, 1998 [1966, 1967, 1968 e 1969].

${ }^{150}$ Cf. MARCUSE, Herbert, 2004 [1975], pp. 161-167 e 2004 [1969], pp. 285-287. Em material de arquivo referente a palestra, realizada em 1967, realça ele a importância de ater-se à Nova Esquerda como movimento representante da busca da emancipação; afinal, encontrava-se em curso a organização da Nova Direita, que também propunha a implementação de mudanças fundamentais na sociedade, entre as quais figuram a supressão dos direitos civis para os 'manifestantes radicais', a intensificação da política de guerra e, finalmente, o anti-intelectualismo. Cf. MARCUSE, Herbert, 30 abr. 1967, pp. 2 e 3. 
representantes militantes da esquerda, em especial, aos estudantes"151. São, portanto, esses grupos antecipadores ou catalisadores que de fato procuravam, então, colocar a descoberto as graves contradições que regem a atual organização do processo de produção e, portanto, da vida social como um todo. E é somente dessa compreensão e da publicização de seus entraves que se pode desenvolver a prática revolucionária.

A observância e a compreensão do funcionamento da totalidade do modo de produção constituem o marco teórico desse protesto. A oposição realiza-se no âmbito mediato, indo além da imediaticidade a que está submetida a relação reificada com o mundo como mercadoria. Afinal, "Marcuse afirma que o capitalismo, para se desenvolver, precisa continuar acumulando. Com esse fim, deve continuar produzindo produtos supérfluos, uma vez que as necessidades vitais já teriam sido satisfeitas, pelo menos nos países ricos. Mas, apesar disso, a desigualdade social não é eliminada, nem sequer nesses países"152. Ao transcender a aparência objetivante colocada pela propaganda de que a satisfação humana pode ser encontrada simplesmente no consumo desenfreado, os movimentos de protesto opõem-se aos aspectos mais fundamentais da lógica de funcionamento 'racional', de um sistema totalitário que molda a razão e a liberdade para os fins da dominação.

Um passo essencial nesse processo consiste em desagregar a relação, mediada pelo trabalho, entre o ser humano e a natureza do modo como está estruturada no capitalismo. O trabalho alienado, constituinte do ser social, somente pode fomentar relações sociais destrutivas. Marx destacou isso com todas as letras no texto que tanto impressionou Marcuse. "Quanto mais o trabalhador se apropria, por meio de seu trabalho, do mundo exterior, da natureza sensível, tanto mais ele se priva de alimentos num duplo sentido, primeiramente, que cada vez mais o mundo exterior sensivel deixa de ser um objeto pertencente ao seu trabalho, um alimento de seu trabalho; e, em segundo lugar, que o mundo exterior, cada vez mais, deixa de ser alimento num sentido imediato, meio para a subsistência física do trabalhador" ${ }^{\prime 153}$. A maneira de levar ao mais alto grau a alienação do ser humano perpassa diversos níveis de estranhamento, em relação a: o seu trabalho, a natureza, os outros e, finalmente, si mesmo. Nem sequer a identificação com o produto de seu trabalho, que ocorria inicialmente, continua existindo.

Precisa-se considerar a atividade executada por cada indivíduo, não de forma abstrata e universal, mas sim concreta e individual, de modo reflexivo no sentido da constituição da identidade como mediada pelo trabalho humano - trabalho esse que resulta

\footnotetext{
${ }^{151}$ MARCUSE, Herbert, 2004 [1972], p. 41

${ }^{152}$ LOUREIRO, Isabel Maria, 2005, p. 18.

${ }^{153}$ MARX, Karl, 1990 [1844], p. 513 - grifos no original.
} 
na produção de objetos, exteriores a cada um de nós. "A objetificação pertence assim à essência do ser humano - como a sua naturalidade - e não pode, portanto, ser 'superada'; de acordo com a teoria revolucionária apenas uma certa forma de objetificação pode e deve ser superada: a reificação, 'alienação" ${ }^{154}$. Trata-se de pensar a atividade humana, desempenhada como a produção dos objetos e utensílios necessários à sobrevivência, não mais como penosa e exploradora, signos por excelência da realidade repressiva, mas como meio efetivo de realização das aspirações de cada indivíduo, que leva a cabo as atividades que lhe proporcionam prazer e estimulam a pulsão erótica, de vida, reduzindo o labor àquela quantidade mínima absolutamente necessária. Esse modo de pensar afigurava-se, pelo desenvolvimento técnico de época, como possível, mas rechaçado pela forma de organização da produção. E o estranhamento em face dessa realidade posta foi reconhecido por esses movimentos de protesto, que procuravam evidenciar a negação desse mundo como uma das etapas insubstituíveis no percurso que leva à revolução dos sentidos. Estavam, portanto, dotados da consciência, requisito indispensável para a prática revolucionária, acerca de suas condições e dos componentes repressivos e destrutivos do sistema de dominação estabelecido.

Ernest Mandel projetou esse mesmo desenvolvimento, relacionando-o precisamente à extensão, a esferas cada vez mais amplas da sociedade, das principais características do trabalho alienante outrora restrito às fábricas. Dessa maneira, "a parcelização $e$ a mecanização do trabalho intelectual fazem correr o risco de provocar, quanto à forma particular e ao objeto específico do trabalho, a mesma indiferença que caracteriza desde há muito tempo o trabalho manual proletarizado. A juventude intelectual não pode aceitar esta degradação, na medida em que se não acantone nos domínios que, devido ao seu próprio conteúdo, são conservadores e têm por objeto a extração e a defesa da mais-valia capitalista. A revolta estudantil é um fenômeno universal do mundo de hoje, mostrando as suas raízes econômicas e sociais, dirigida essencialmente contra as conseqüências alienantes da proletarização do trabalho intelectual na sociedade mercantil"155. Nesse trajeto de proletarização, está dada outra forma que descreve a aproximação entre os revoltosos, privados de direitos adquiridos e submetidos a condições cada vez piores, o que traz à tona os sentimentos de contestação a essa organização societal.

$\mathrm{Na}$ medida em que a oposição visa a crítica da totalidade social, destaca-se seu caráter 'elitista', por encontrar-se restrito a uma pequena camada da população - afinal,

\footnotetext{
${ }^{154}$ MARCUSE, Herbert, 2004 [1932], p. 524 - aspas no original. Em ambos os casos dessa citação o verbo "superar" refere-se ao alemão "aufheben".

${ }^{155}$ MANDEL, Ernest, 1979 [1972], p. 67.
} 
aqueles que são dogmaticamente concebidos como a massa revolucionária estão alijados do acesso aos meios que contribuem para a educação esclarecedora. "No estágio contemporâneo, a Nova Esquerda é obrigatoriamente e essencialmente um movimento intelectual, e o anti-intelectualismo praticado em suas próprias fileiras trabalha de mãos dadas com o establishment ${ }^{\prime 156}$. O movimento nem deve nem pode, para adequar-se a um pseudo-marxismo reificado, rejeitar a sua dimensão teórica, pelo contrário: a força reside na incorporação do instrumental crítico contido em uma educação política que possibilite elaborar projeções concretas da emancipação futura.

É necessário remeter ao fato de que o intelectual, como entendido no pensamento marcuseano, não se relaciona de modo estrito àquelas pessoas que se encontram inseridas na universidade, em institutos de pesquisa ou órgãos governamentais que tenham a função de formar a opinião pública. Pode-se, eventualmente, encontrá-lo sob todas essas condições, mas, da mesma forma, um estudante desligado do sistema de ensino estabelecido, ou um conjunto qualquer de pessoas que sequer adentrou essa esfera, ao praticarem uma educação política que tenha como conteúdo essencial a crítica da realidade vigente e a exposição dos modos como transcorre a dominação devem, também, ser considerados intelectuais. Isso quer dizer que já desde esse momento a condição de intelectual apresenta-se como extremamente dúbia, por não traduzir, necessariamente, uma relação determinada com o processo de produção.

A premência concedida à figura do intelectual no contexto do capitalismo decorre, como procurei demonstrar até agora, do ganho de importância da educação superior como um todo e, desse modo, da ciência e da tecnologia, em virtude de sua crescente importância para o processo de produção. Essa trajetória expressa, para Marcuse, a mais relevante contradição encerrada nessas novas relações sociais: "Da mesma forma que a esfera da dominação concede à democracia existente espaço para erigir bases locais autônomas, as exigências científico-tecnológicas crescentes da produção e do controle fazem das universidades uma base dessas: primeiramente para o próprio sistema - como locais de preparação [Ausbildungsstätten] de seus quadros - mas simultaneamente, pelo mesmo motivo, também para a educação de futuros contra-quadros" ${ }^{\prime 157}$. É retomada, portanto, a idéia que já se encontrava em Marx, do capitalismo ser produtor dos próprios coveiros. Sem a aceitação dessa abertura para a expressão institucional das contradições, não é possível compreender a argumentação de Marcuse com referência às possibilidades de

\footnotetext{
${ }^{156}$ MARCUSE, Herbert, 2004 [1972], p. 39 - grifos no original.

${ }^{157}$ MARCUSE, Herbert, 2004 [1972], p. 59 - grifo no original.
} 
desenvolvimento da contestação radical sob o capitalismo organizado de meados do século XX. O ponto de partida para a prática emancipadora situa-se, portanto, necessariamente em termos da conscientização, percepção, apreensão mediada e avaliação crítica da realidade imediatamente dada, procurando extrapolar a racionalidade parcial para revelar, assim, a organização irracional da totalidade social.

As possibilidade restantes são, assumidamente, parcas - e todas relacionam-se a uma esforço enorme em prol da atuação conjunta de diversos movimentos, que precisam orientar-se pela teoria. E essa teoria, isso deve ficar claro, é uma teoria profundamente diferente daquela praticada nas universidades de então. "Quando a própria ideologia, a própria razão tornam-se meios de dominação, que são reproduzidos pelos indivíduos, então está dada a necessidade de uma contra-psicologia, de uma contra-sociologia, de uma contra-razão, de uma contra-educação. Isso quer dizer, em contradição à fusão capitalista de cultura material e intelectual, de razão e ideologia, vale agora a senha da libertação do trabalho intelectual para a sua própria autonomia: intelligentsia em contradição"158.

Retomando agora de forma mais minuciosa o diagnóstico acerca do ensino superior e dos estudantes, é cabível analisá-los como um sujeito em alguma medida contraditório em si mesmo. Avento isso em virtude da tradicional origem de classe burguesa, discussão levantada mesmo pelos trabalhadores e sindicalistas, durante os protestos de maio de 1968. Isso lhes oferece, em tese, as mais diretas possibilidades de integração ao status quo. Simultaneamente, o conhecimento adquirido acerca da sociedade capitalista possibilita-lhes vê-la sob outros olhos, reconhecer os problemas estruturais que lhe são inerentes. Concomitantemente, muitas vezes os estudantes dispõem de bastante tempo livre, ao menos quando comparado aos trabalhadores, de forma que é muito mais plausível tomarem para si a organização de protestos e o descobrir, em debates e grupos de discussão, os diversos malefícios subjacentes à nossa vida diária. Contudo, esse estado de coisas carrega em si o germe de encerrar a organização da resistência em horizontes muito limitados, restringindo as reivindicações a particularidades. Um primeiro entrave está exatamente em ficar aquém do momento em que "houve o reconhecimento de que a universidade é afinal apenas uma parte da sociedade mais ampla, do establishment $e$, a não ser que o movimento se estendesse para além da universidade e atingisse os pontos mais vulneráveis da sociedade como um todo, permaneceria isolado" ${ }^{159}$. A tentativa política nessa direção defrontou-se

\footnotetext{
${ }^{158}$ MARCUSE, Herbert, 2004 [1974b], pp. 155 e 156 - grifos no original.

${ }^{159}$ MARCUSE, Herbert, 1999 [1968], p. 62 - grifo no original.
} 
recorrentemente com as diferenças de perspectiva dos sindicatos trabalhistas e partidos de esquerda.

Uma problemática interna a esse contraponto é a do debate, para chegar-se aos extremos das considerações no âmbito da politização, em torno da manutenção ou não da universidade em seu todo e de sua base teórica. O fundamento dessa crítica nasceu do reconhecimento da função reprodutora da ordem da instituição. A questão consiste, talvez, em pesar para qual das formas de pensamento a universidade detém maior importância. Assim Marcuse reconhece a disparidade de posições existente quanto à importância desse movimento como vetor de mudança, e lembra que "o movimento estudantil não deveria esquecer que é um movimento intelectual e que vive da teoria, mesmo quando caçoa da teoria" ${ }^{160}$. Delimitando a ascensão de uma das principais organizações oposicionistas como intrinsecamente dependente do fundamento pensante e teórico oferecido pela universidade moderna, é o mero ataque a esta bastante questionado. Realmente, " $a$ universidade certamente necessita de uma reforma radical, porém esta reforma radical deveria ser levada a cabo na própria universidade e não tomar a forma de destruição da universidade. Pois destruir a universidade significaria de fato que reduzimos ou eliminamos completamente... bem, deixem-me dizer isto de modo muito extremo e provocativo, destruir a universidade é cortar o galho em que nos sentamos. Porque, afinal de contas, é na universidade que a oposição cresce, que a oposição é educada e se educa, e destruir a universidade pode causar um prejuízo maior para nós do que para eles" ${ }^{\prime 61}$. Portanto, as possibilidades de ressignificação do modo pelo qual se dão as relações professor-aluno e dos ideais que regem o ensino superior hão de pautar-se pela perspectiva da transformação. Já despida de espaço e oportunidades no mapa dos poderes econômicos e políticos, objetiva-se uma situação de risco para a construção da oposição. É necessário, de acordo com esse raciocínio, refletir de modo mais estrutural acerca das implicações de cada reivindicação.

De qualquer modo, predominantemente como conseqüência do que interpretava como o despontar de um movimento radicalmente diferente das manifestações da oposição tradicional, tanto em sua forma de organização quanto nos conteúdos de sua revolta, era indubitável a preeminência concedida por Marcuse aos estudantes no desenrolar desse processo. "Apesar dele, em virtude das tendências excepcionalmente fortes à interiorização [Innerlichkeit], descrever o caráter político dos contramovimentos, socioculturalmente

\footnotetext{
${ }^{160}$ MARCUSE, Herbert, 1999 [1969], p. 106.

${ }^{161}$ MARCUSE, Herbert, 1999 [1968], p. 70.
} 
caracterizados, como ambivalente, ainda assim concedia-lhes preferência em face das tradicionais organizações de esquerda e dos sindicatos, que ainda se prendiam, de modo ininterrupto, à reprodução de um progresso destrutivo. Essas forças de um progresso qualitativo, ainda imaturas, estavam representadas nos movimentos das mulheres, dos estudantes e ecológico"162.

A centralidade da população estudantil como um todo para gerar um impulso transformador (e não somente do movimento, apesar dele ser premente), decorre do desenvolvimento exposto acima, envolvendo a reorganização da esfera do trabalho e o aprofundamento do mecanismo de dominação que compreende um conteúdo marcado por uma racionalidade específica, a instrumental. Referindo-se ao papel dos estudantes no período em questão, a sua opinião é bastante clara: "Nunca afirmei que o movimento estudantil substitui, hoje, o movimento operário como possível sujeito da revolução. O que disse é que o movimento estudantil funciona hoje como um catalisador, como preparador do movimento revolucionário, e este papel é hoje de fato extraordinariamente decisivo. Creio que todas estas declarações derrotistas, de que um movimento limitado, em geral, às universidades e às escolas superiores não pode ser um movimento revolucionário e que é apenas um movimento de intelectuais - do que se denomina de uma elite - não levam em conta os fatos, pois é precisamente nas universidades e nas escolas que se educa e treina hoje os quadros da sociedade futura e que, por isso, o desenvolvimento da consciência e do pensamento crítico, que tem lugar nas universidades e nas escolas, é uma tarefa decisiva" ${ }^{" 163}$. O movimento estudantil é utilizado por ele freqüentemente como o epíteto de uma constelação mais ampla de grupos oposicionistas que se fez presente naquele período. Um das principais questões em aberto constitui a organização desses movimentos dispersos para uma frente única de protesto. Em relação à amplitude da base de esquerda, repetidamente criticada, Maria Ribeiro do Valle coloca: "Ainda não há, apesar da eclosão dos movimentos estudantis, de libertação colonial, dos direitos civis, dos hippies, uma organização solidária que promova a confluência de tendências tão diversas. As contestações econômicas, políticas e culturais, tanto no Ocidente como no Oriente, são consideradas por Marcuse - que em momento algum deixa de reconhecer suas limitações forças que permitem vislumbrar a 'realização da utopia', desde que estejam dirigidas à ruptura do sistema" ${ }^{\text {164 }}$. Transparece em seu comentário, novamente, a dialética entre

\footnotetext{
${ }^{162}$ KRAUSHAAR, Wolfgang, 2004, p. 23.

${ }^{163}$ MARCUSE, Herbert e POPPER, Karl, 1971, pp. 16 e 17.

${ }^{164}$ VALLE, Maria Ribeiro do, 2005, pp. 107 e 108 - aspas no original.
} 
reforma e revolução presente no pensamento marcuseano ${ }^{165}$. Ele jamais se furtava a conceder a devida importância a certas reformas em contextos específicos, mas alertava sempre para os cuidados que precisavam ser tomados para evitar a guinada rumo a um reformismo, historicamente representado pela social-democracia, cujo intuito era unicamente arrefecer as energias emancipatórias e deter, com a promessa de um futuro melhor (todavia, sempre distante), o ímpeto revolucionário.

Da mesma maneira relacionam-se, em sua teoria, as idéias das mudanças quantitativa e qualitativa. Ambas estão ligadas uma à outra na medida em que somente o desenvolvimento quantitativo das forças produtivas, traduzido em progresso das forças técnicas de produção, pode proporcionar as condições necessárias (mas não suficientes) para o assim-chamado salto qualitativo. Diferentemente, o continuado empreendimento de reforma após reforma não constitui condição prévia para a revolução. "Eu gostaria de apontar que a distinção entre a mudança quantitativa e a mudança qualitativa não é idêntica àquela entre reforma e revolução. A mudança quantitativa pode significar e pode levar à revolução. Penso que somente a conjunção dessas duas é revolução no sentido essencial do salto da pré-história para a história do ser humano" ${ }^{" 166}$. Conseqüentemente, as mudanças quantitativas sempre detiveram um papel importante no pensamento marcuseano.

Indo ao encontro de uma crítica de Kellner, Marcuse efetivamente não oferece respostas práticas ou modelos de ação à questão de como pode ocorrer a união dessa ampla gama de movimentos em busca da emancipação numa grande força que, quem sabe, pudesse até mesmo fomentar a revolução. A única linha-guia que fornece se relaciona à necessidade da educação como alavanca da negação. "Certamente, na sociedade repressiva e contra o seu aparato onipresente, a espontaneidade como tal não pode, de forma alguma, ser uma força radical e revolucionária. Ela pode tornar-se tal força apenas mediante esclarecimento, educação e prática política, e esses seriam, nesse sentido, de fato o resultado de organização" ${ }^{167}$. Remetendo ao entendimento de, ao menos, "educação" e "esclarecimento" serem funções atribuídas ao intelectual (num sentido lato), fica essa como uma das únicas alternativas possíveis para a 'praticidade' da teoria social transformadora, conforme procurarei detalhar no último sub-item de meu texto.

\footnotetext{
${ }^{165}$ Tal encadeamento engloba, também, a tentativa de fazer uso, num primeiro momento, dos meios formais da democracia liberal burguesa. O seu limitado alcance está claro desde já mas, simultaneamente, a sua vasta possibilidade de atingir uma ampla população torna-os um dos instrumentos necessários. "Reivindicações e ações que em outras situações foram rejeitadas, de forma justa, como política liberalburguesa, economicista e reformista, podem ter hoje um significado positivo: o capitalismo tardio acusa um limiar de tolerância reduzido". MARCUSE, Herbert, 2004 [1975], p. 168; cf. ainda Id., ibid., p. 167.

${ }^{166}$ MARCUSE, Herbert, 28 jul. 1967, p. 5.

${ }^{167}$ MARCUSE, Herbert, 2004 [1969], p. 315.
} 
No intuito de matizar e, desse modo, empreendendo o rigor necessário a uma análise efetivamente crítica desse processo de conscientização, Marcuse não se cansa de remeter à importância da intelectualidade nesse contexto, fazendo sempre a ressalva de não se tratar de uma classe ou de um portador da revolução. "Podemos dizer que a intelligentsia é o agente da mudança histórica? Podemos dizer que a intelligentsia, hoje, é uma classe revolucionária? A resposta que eu daria é: não, não podemos dizê-lo. Mas podemos dizer, e penso que devemos dizer, que a intelligentsia tem uma função preparatória decisiva. Não mais que isso, e eu sugiro que isso é bastante" ${ }^{\text {168 }}$. E essa é, reconhecidamente, não somente uma atribuição atual, do século XX, mas sim uma constelação que decorre da modernidade, da ascensão das matrizes de pensamento burguesas sob a linha-guia do conhecimento teórico.

Com referência ao modo de conciliar as reformas e o trabalho de protesto surge a filiação à "longa marcha através das instituições" preconizada por Dutschke, sob a idéia de revolucionar as instituições por dentro, de fazer com que os seus 'dirigentes' passem a raciocinar baseados em outra forma de razão. A relação intrínseca entre teoria e prática, traduzida na presença da dialética entre esclarecimento e ação, foi o principal tema do debate entre ambos. A existência de cisões nos movimentos de esquerda, entre as facções marxistas e trotzkistas, e as críticas à concepção de Marcuse da classe trabalhadora integrada e conservadora foram outros assuntos recorrentemente abordados ${ }^{169}$. Nesse sentido apresenta-se a convergência entre ambos quanto à importância do trabalho teórico de modo geral, abarcando a conscientização, constituída de pequenos passos, com vistas à disseminação do pensamento de oposição ao sistema estabelecido. Vem à tona, portanto, a necessidade premente de trabalhar em várias frentes, não deixando de lado pequenos grupos rotulados de elites pelos 'marxistas' dogmáticos.

A adoção do critério materialista histórico-dialético para determinar as fontes do possível questionamento radical aos fundamentos do sistema de exploração vigente busca ir além das formas de organização que foram fetichizadas como 'democráticas' com o passar do tempo: tanto os ditames da democracia representativa burguesa quanto a organização partidária centralizada utilizada pelos socialistas ao início do século XX. Em tal âmbito transparece a perspectiva de que é precisamente “[o] caráter 'não-ortodoxo' dessa oposição, que não dispõe de uma tradicional base classista e que é simultaneamente uma

\footnotetext{
${ }^{168}$ MARCUSE, Herbert, 28 jul. 1967, p. 13.

169 Cf. DUTSCHKE, Rudi e MARCUSE, Herbert, 2004 [1967-1979]. As dificuldades materiais e ideológicas com as quais ambos se defrontavam em sua prática diária foram também problematizadas por serem constantemente vítimas de perseguições e calúnias.
} 
rebelião política, pulsional e moral, molda a sua estratégia e o seu alcance. Ela abrange toda a organização da democracia liberal-parlamentar existente. Na Nova Esquerda impôs-se uma rejeição enfática das tradicionais práticas políticas: da rede de partidos, comitês e grupos de interesse em todos os níveis, de qualquer trabalho junto à essa rede e com os seus métodos" ${ }^{170}$. Qual há de ser a força dessa nova condição oposicionista? A primeira ressalva de Marcuse provavelmente seria a de que não se trata de uma novidade, já que sempre houve questionamentos ao modus operandi da sociedade de classes, mesmo que limitado e localizado, em estratos sociais diferentes da classe operária. Esclarecido esse ponto, volto-me para o fato de que a presença e a disseminação da uma mentalidade de protesto é, por si só, uma vitória. Aqui não vem ao caso se se trata de uma oposição dessa ou daquela classe e, como ele repetidamente enfatiza, essa jamais foi uma questão para Marx e Engels: o problema para eles era a forma concreta de levar a cabo uma transformação social radical, e não a idéia abstrata e reificada de que a classe operária estava, por algum motivo transcendental, destinada a ser a portadora dos desejos e anseios pós-exploração.

Paul Sweezy trata desse problema ao discutir a constituição histórica do proletariado como um elemento presente na teoria de Marx, destacando justamente o fato dessa alteração histórico-estrutural não tornar inválida a própria teoria acerca da sociedade capitalista, que continua baseada sobre o processo de acumulação. Ele aborda inclusive a própria noção do aburguesamento da classe trabalhadora pela via da incorporação da ideologia burguesa em seus variados níveis: a presença cada vez mais rara dos blue collars leva esses novos trabalhadores a planejarem a vida dos seus filhos como uma vida pequenoburguesa, incluindo nela, entre outros, o acesso ao ensino superior e a possibilidade de mobilidade social ${ }^{171}$. Nesse sentido, inclusive, o proletariado de Marx não foi, desde sempre, uma classe histórica, mas tornou-se uma em virtude do detrimento da produção manufatureira em benefício da produção 'tecnológica' industrial. A mudança qualitativa do processo de trabalho no capitalismo monopolista alterou, também, a base produtiva em termos da força de trabalho, mas não alterou as características fundamentais do modo de produção, afinal, nesse caso não mais se poderia falar em capitalismo.

\footnotetext{
${ }^{170}$ MARCUSE, Herbert, 2004 [1969], p. 293 - aspas no original. Ver também MARCUSE, Herbert, 1998 [1969c]. Com relação às vozes de protesto em face das condições sociais e históricas daquele momento escreve Mills: "Em terceiro lugar, quem se está saturando com isso? Quem se está desgostando daquilo que Marx chamava de 'velhos glutões'? Quem está pensando e agindo de formas radicais? Em todo o mundo - no bloco, fora dele, e entre eles - a resposta é a mesma: a intelectualidade jovem". MILLS, Charles Wright, 1965 [1960], p. 134 - aspas no original.

${ }^{171}$ Cf. SWEEZY, Paul Marlor, 1972 [1967], em especial pp. 159-161.
} 
É desse modo que se põe como fundamental a noção de que todo teórico efetivamente crítico deve debruçar-se sobre essa 'nova' (e, portanto, estruturalmente diferente) realidade histórica para efetuar uma análise que possa ser dita marxista. E a pedra fundamental para a realização dessa crítica reside na atenção à mediação correta da teoria e da prática, motivo pelo qual Marcuse enfatizou repetidamente a distinção entre um momento pré-revolucionário e o próprio processo revolucionário e, portanto, analisou os sujeitos de acordo com essa divisão. "A unidade da teoria e da prática jamais existe imediatamente. A realidade social dada, que ainda não é dominada pelas forças da transformação, requer uma conformação da estratégia às condições objetivas - a condição prévia para a sua transformação. Uma situação não-revolucionária diferencia-se essencialmente de uma situação pré-revolucionária ou revolucionária. Somente uma análise teórica pode determinar e distinguir o estado dominante e o seu potencial ${ }^{172}$. Essa linha de raciocínio visa dar conta das incessantes demandas postas pelos movimentos em busca de uma espécie de aplicação das bases teóricas na ação, algo rejeitado pelos pensadores da teoria crítica da sociedade. Afinal, os intelectuais devem, por meio de sua reflexão, provocar o esclarecimento e a tomada de consciência dos indivíduos, mas de modo algum liderá-los como uma massa amorfa, da maneira como tradicionalmente os partidos o fizeram.

Daí o uso do termo "catalisador" em seu argumento. Isso significa que não se trata, de modo imediato, daqueles que irão levar a cabo a revolução, mas sim de indivíduos e grupos que podem deflagrar o desenvolvimento de uma consciência oposicionista. "Jamais afirmei que os movimento dos estudantes ou dos negros representasse uma força revolucionária em si, mas que eles agem como catalisadores e que nisso reside hoje um significado histórico extremamente importante. Esses grupos, em especial os estudantes, expressam a consciência que, na verdade, é a consciência de toda a população dependente, mas que nessa população ainda não aparece de forma articulada. Esses grupos precisam, por meio de um longo e doloroso processo de esclarecimento político e educação, oferecer uma contribuição decisiva para o desenvolvimento da consciência política" ${ }^{173}$. Remeto ainda ao fato de que se trata de grupos que detêm em comum entre si, quando analisada sua posição no processo de produção e sua origem de classe, somente a rejeição dos valores

\footnotetext{
${ }^{172}$ MARCUSE, Herbert, 2004 [1972], p. 41.

173 MARCUSE, Herbert, 1998 [1972b], pp. 759 e 760. Maria Ribeiro do Valle interpreta da seguinte forma: "A vanguarda intelectual, que recusa a ordem vigente e tem dela uma visão mais global, também deve atuar como catalisadora dessas novas forças, por meio da educação política. Está presente aqui a idéia de revolução, na esteira da teoria marxista, no sentido em que ela tem sua realização possível na junção da teoria crítica com aqueles que, 'livres' das benesses do sistema, são movidos pela necessidade". VALLE, Maria Ribeiro do, 2005, pp. 114 e 115 - aspas no original.
} 
estabelecidos. É desse modo que se fazem presentes, em cada um deles, pontos fulcrais diferentes para o questionamento do todo - é 'somente' essa oposição que os unifica, o que também explica as divergências que vieram à tona durante a prática política de protesto.

Ou seja, de modo geral, é a exploração dissolvente de tudo o que compõe essa sociedade, desde as máquinas, passando pelos bens de consumo até os trabalhadores, que expõe os indivíduos que a integram à constante e forçosa conformação a esse modus vivendi. Sob esse prisma, a referência ao movimento ecológico, por exemplo, está calcada em sua apresentação como um importante grupo de contrabalanceamento por meio de um duplo movimento emancipatório: a) politicamente, ao postar-se contra os interesses do grande capital em dominar a natureza e b) psiquicamente, ao difundir um ideal de preservação a ser incorporado por cada indivíduo sob a égide do princípio do prazer, do domínio de Eros, o que necessariamente leva a uma redução da energia pulsional de Thanatos, arrefecendo os ímpetos de destruição ${ }^{174}$. É central, para tanto, o que Marcuse denomina de política da energia erótica, promovendo novos valores, comportamentos e ações de protesto diferentes da oposição tradicional. A marginalidade e a impotência inicial dessas formas de oposição demonstram sua autenticidade, já que se opõem efetivamente ao princípio de realidade vigente.

\subsection{Uma revolução com caráter: entre meios e fins}

A questão da educação permeava, de diversos modos, os debates emancipatórios (ou libertários) da época: fosse pelo viés da inclusão nesse sistema de ensino, que aparecia como requisito indispensável para a inserção e a mobilidade sociais, fosse pelo viés da contestação de toda sua organização e prática, alinhadas ao sistema econômico-políticomilitar. Dito isso, é possível compreender a 'raiz empírica' da preocupação com a educação nos escritos de Marcuse. Voltar-me-ei, agora, às principais características de sua concepção de educação, enfocando-a, assim, como um vetor de mudança social.

Salta aos olhos, no modo de construir sua teoria social, o enfoque análogo concedido por Marcuse ao binômio técnica e ciência vis-à-vis a educação, ambas vistas como proporcionando elementos fundamentais tanto para perpetuar a dominação quanto para fomentar a emancipação. Ele esquematiza a tensão, em 1968, da seguinte maneira:

\section{“A dialética da educação nessa sociedade:}

${ }^{174}$ Cf. MARCUSE, Herbert, 1998 [1977a]. 
- dependência crescente da educação, conhecimento irrestrito no processo econômico competitivo,

- e na direção do processo político;

E, ao mesmo tempo, crescente necessidade de 'conter' o conhecimento e a razão no interior do universo conceitual e de valores da sociedade estabelecida e de sua melhoria $e$ crescimento; com o intuito de proteger essa sociedade contra a mudança radical;

Resultado:

- ênfase sobre o treinamento profissional, vocacional,

- declínio das 'humanidades'

- declínio do pensamento crítico, transcendental" ${ }^{175}$.

O debate em torno dos modos que a educação pode e deve assumir, assim como, conseqüentemente, das possibilidades e dos sujeitos da emancipação, estão marcados por algumas tensões. No caso específico da educação, a remissão ao lúdico e aos fundamentos da arte como um dos elementos centrais de uma educação para a emancipação faz-se presente de modo explícito desde Eros e civilização, tendo como ancoragem o subsídio freudiano da fantasia como fomento da pulsão erótica ${ }^{176} \mathrm{e}$, portanto, fornecendo elementos que podem possibilitar, dependendo de sua contextualização, uma base pulsional para o pensar de uma sociedade radicalmente diferente. É também nesse momento que é feita a primeira referência à importância da grande recusa, conceito trazido de Alfred Whitehead ${ }^{177}$, para estruturar esse pensamento transcendente. O conteúdo da grande recusa, imbricado na busca pela felicidade da pulsão de vida, só faz sentido quando pensado no contexto de uma transformação do princípio de realidade e, portanto, dos valores que orientam o julgamento humano. Historicamente, a ultrapassagem do princípio de desempenho que incita à competição destrutiva entre os seres humanos esteve presente na arte que figura, assim, como guia nessa teorização. Como pode ser observado nos escritos marcuseanos acerca da estética, é no artista que se encontra, em diversos momentos, a recusa da realidade dada.

O ponto central está na capacidade de projetar uma alteridade ao existente, e esse é o critério que orienta a interpretação dos fenômenos culturais. Assim, para Marcuse, a

\footnotetext{
${ }^{175}$ MARCUSE, Herbert, 1968, p. 3 - aspas e grifos no original. Na referência aqui trata-se de um manuscrito, constituído de anotações referentes a uma palestra, que encontrei em seu arquivo, em Frankfurt, motivo pelo qual o texto encontra-se fragmentado.

${ }^{176}$ Cf. MARCUSE, Herbert, 2004 [1955], pp. 124-134.

${ }^{177}$ Cf. MARCUSE, Herbert, 2004 [1955], p. 131. Kellner, quando trata da origem do conceito da grande recusa em Marcuse, oscila entre o reconhecimento (de fato curioso) da remissão a Whitehead e a filiação marcuseana à recusa como preconizada pelo surrealismo, notadamente por André Breton. Cf. KELLNER, Douglas, 1984, pp. 174 e 279, em especial as notas 39 (capítulo 6) e 5 (capítulo 9).
} 
mudança nos padrões das relações e das práticas sexuais não significa libertação enquanto se mantiver nos limites da socialização possível no interior do sistema dominante. $\mathrm{O}$ conceito de "dessublimação repressiva" expressa esse entendimento: "Eu chamei a liberalização da moralidade sexual de dessublimação repressiva; um conceito paradoxal, pois toda dessublimação é, em si mesma, redução da repressão, mas o é, somente, quando resulta de liberdade e satisfação individuais. A dessublimação autêntica, não-repressiva, seria a liberação de energia erótica, e não apenas sexual, e, o mais importante, manifestaria uma des-socialização em relação a uma sociedade repressiva, uma dissociação em relação a uma sociedade repressiva. Uma dessublimação autêntica significaria que as necessidades pulsionais por privacidade, por quietude, por carinho, por solidariedade, por paz, de fato ganham ascendência sobre e acima das pulsões destrutivas e competitivas. Pois as pulsões eróticas são verdadeiramente pulsões de vida, prevalecendo sobre a destruição e a agressão, prevalecendo sobre a crueldade e a violência e visando [striving] a criação de um ambiente verdadeiramente pacificado e humano" ${ }^{" 178}$.

Desse modo, o caráter da vida efetivamente não-reprimida que, portanto, proporcionaria a solidarização entre os seres humanos e entre estes e a natureza dependia, fundamentalmente, do desenvolvimento de uma espécie de sensualismo estético. Sem que fosse concedido um papel relevante à sensibilização artística, seriam nulas as chances de uma alteração emancipatória do ser social. "Em um mundo dominado pelo totalitarismo, sugere Marcuse, a oposição estética e o amor são as forças de oposição mais radicais, uma vez que produzem uma realidade alternativa completamente avessa a uma realidade social opressiva. A arte transcende a vida diária em virtude de sua forma, por sua habilidade em produzir um outro mundo que projeta imagens de uma vida melhor e revela as deficiências e horrores da realidade existente ${ }{ }^{179}$. Em grande medida, essa mesma tarefa estava associada ao materialismo histórico-dialético: projetar um outro possível, mas que necessariamente precisa estar materialmente calcado sobre o existente.

\footnotetext{
${ }^{178}$ MARCUSE, Herbert, maio 1965, p. 6. Maria Teresa Cardoso de Campos afirma o seguinte no que se refere a essa temática, oferecendo uma visão acurada do pensamento de Marcuse: "A liberação sexual é aparente porque segue um modelo imposto de organização sexual, que impõe a centralização da sexualidade, isto é, a primazia da genitalidade, da procriação e a unificação dos objetos libidinais em um único objeto do sexo oposto e, ainda, na maioria das vezes, a monogamia. Os comportamentos sexuais que diferem desse modelo são, então, sublimados ou adquirem o status de perversões, que são as manifestações sexuais que não visam a procriação. Pode-se dizer, então, que a sexualização permitida, na verdade, é dessexualização, pois a libido deve concentrar-se apenas nas zonas erógenas, implicando na dessexualização do organismo como um todo. A energia sexual é controlada, 'administrada' e o prazer é conformado às necessidades sociais". CAMPOS, Maria Teresa Cardoso de, 2004, p. 47 - aspas e grifo no original.

${ }^{179}$ KELLNER, Douglas, 1999 [1998], p. 58.
} 
A dimensão estética (ou seja, a capacidade de imaginação (Einbildungskraft)) detém, pois, um papel-chave no que se pode denominar 'reeducação' do ser humano. A referência às Cartas sobre a educação estética do ser humano, de Friedrich Schiller, é um parâmetro fulcral da argumentação marcuseana ${ }^{180}$. É nela que se faz presente uma dialética entre a estética como mediadora dos sentidos humanos e a estética como busca do belo. Deveríamos preocupar-nos em unir a satisfação das nossas pulsões primárias, ou seja, das necessidades absolutamente vitais, mantendo ao mesmo tempo a baliza de erigir um meioambiente bonito, em que as pessoas não olhem a todo o momento à sua volta e constatem, de modo imediato, o seu desgosto com as formas e os conteúdos do que os rodeia ou, mediadamente, tenham de conviver com as injustiças e os comportamentos absurdos que proporcionam essa beleza aparente.

Nessa perspectiva, o artista define-se pelo distanciamento crítico face à realidade dada, o que, na língua alemã, é descrito por meio do termo Entfremdung (estranhamento ou alienação). Marcuse esclarece a idéia: "Em contraposição ao conceito de Marx, que designa a relação do ser humano consigo mesmo e com o seu trabalho na sociedade capitalista, o estranhamento artístico é a transcendência consciente da existência alienada - uma alienação em um 'nível superior' ou uma alienação mediada. O conflito com o mundo do progresso, a negação da ordem dos negócios, os elementos antiburgueses na literatura e na arte burguesas não decorrem da inferioridade estética dessa ordem nem de uma reação romântica - a consagração nostálgica de um estágio da civilização em desaparecimento" ${ }^{181}$. É essa a essência da adoção de uma perspectiva estética da realidade subsumida à capacidade de imaginação e que, em Schiller, está enraizada no aspecto lúdico da formação humana, na idéia de jogar/brincar (spielen). Enquanto a faculdade de julgar estiver atada à realidade imediatamente posta, apreendida como verdadeira, de forma alguma será possível trilhar o caminho da emancipação.

Com essa elaboração, Marcuse busca resgatar o sentido crítico e a dimensão negativa da cultura, domesticada por sua apropriação pela civilização, que a reduz a produtos padronizados de entretenimento e propaganda. É no âmbito da cultura negativa

\footnotetext{
${ }^{180}$ Cf. SCHILLER, Friedrich, 1951 [1793-1794]. O capítulo IX de Eros e civilização é intitulado "A dimensão estética”. Para a referência a Schiller, cf. MARCUSE, Herbert, 2004 [1955], p. 158 e segs.; assim como, para outro comentário acerca da aproximação entre ambos ver BEHRENS, Roger, 2005, p. 3. Posteriormente, Marcuse volta a referir-se ao modo como a fantasia é um componente constitutivo da luta pela emancipação: "A teoria marxiana logo reconheceu que a pauperização não fornece necessariamente a base para a revolução; que uma consciência altamente desenvolvida e uma fantasia altamente desenvolvida são capazes de originar um interesse vital na transformação radical das condições materiais avançadas". MARCUSE, Herbert, 2004 [1969], p. 255.

${ }^{181}$ MARCUSE, Herbert, 2004 [1964a], pp. 79 e 80 - grifos e aspas no original.
} 
que a arte se reaproxima da teoria crítica. De fato, "a tensão entre o possível de ser [Seinkönnenden] e o que está sendo [Daseienden], entre aquilo que o ser humano e as coisas podem ser e aquilo que eles de fato são, é uma das manivelas centrais da teoria. Ela vê nela não uma estrutura transcendental do ser e uma diferença ontológica inalterável, mas sim uma relação histórica que deve ser superada [aufzuheben] pelos seres humanos nessa Terra: um estímulo para o conhecimento tornar-se o momento da prática transformadora" ${ }^{\prime 182}$. Os conceitos aqui opostos são o fato (Tatsache) e a possibilidade (Möglichkeit). O ponto é o de distinguir entre os indivíduos e a humanidade como realidade dada, nesse momento específico analisado, e os horizontes que estão ao seu alcance. As aspirações flutuam no embate dialético entre o existente (o que está sendo) e o possível de ser, uma contradição que não é indissolúvel conquanto apreendida de modo mediado.

O critério central subjacente à expressão do trabalho de um artista é a sua rejeição da realidade posta, é a afirmação de um outro mundo. Essa força negativa, entendida como um desejo absoluto, ou seja, originada das entranhas, das pulsões, da 'natureza' daquele ser humano, expressa a recusa de partilhar os valores contemporâneos. A arte mantém-se, portanto, como aparência na medida em que não é, mas projeta uma outra realidade, constituindo, assim, uma dimensão fortemente política ${ }^{183}$. A alteridade sinaliza o possível e, em seu registro, pode-se pensar a sociedade como uma obra de arte, ressaltando a dimensão lúdica e estética da educação política.

A ênfase sobre a arte e a capacidade de imaginação como fontes para a revolta subjetiva encontra-se mais desenvolvida no Ensaio sobre a libertação. Sob o conceito da nova sensibilidade, expressa-se tal conjunção de fatores ${ }^{184}$ : da arte como portadora da utopia emancipadora sob a égide do ethos estético; do conteúdo político presente na contracultura; da perspectiva da fantasia e do belo como indicativa da existência de uma visão radicalmente diferente da realidade. É assim que se observa uma concertagem em que a estética é apreendida em sua capacidade de ultrapassar os limites da aparência imediata, estando essas aspirações vitais ancoradas, também, sobre os fundamentos psíquico-sociais que constituem o ser humano ${ }^{185}$.

\footnotetext{
${ }^{182}$ MARCUSE, Herbert, 2004 [1936], pp. 68 e 69; cf. também Id., ibid., p. 70 e Id., 2004 [1965a]. ${ }^{183}$ Cf. MARCUSE, Herbert, jul. 2001 [1967].

${ }^{184}$ Cf. MARCUSE, Herbert, 2004 [1969], pp. 261-281 e, à p. 281, a seguinte conclusão: "Em virtude dessa antecipação é que a dessublimação da cultura realizada de modo desorganizado, bruto, burlesco, artístico constitui um elemento essencial da tática de política radical: o das forças subversivas em transição [umstürzenden Kräfte im Übergang]". Ver também, em relação à arte revolucionária, o capítulo terceiro de Contra-revolução e revolta. Cf. MARCUSE, Herbert, 2004 [1972], pp. 81-123.

${ }^{185}$ Essa construção foi um dos alvos da crítica ao 'transcendentalismo' de Marcuse. Respondendo a uma interpelação desse tipo, ele explica: "Transhistórico significa transcender a todo e qualquer estágio
} 
É a partir desse enfoque que minha ênfase aqui dirige-se à concepção de educação situada no âmbito da transformação social. Ou seja, para além das teorias de socialização da sociologia, que classicamente se preocupam com a conformação e a inserção do indivíduo na sociedade existente, objetivando a reprodução da ordem ${ }^{186}$, o adjetivo "crítica" ou "política" é um aspecto fundamental para qualificar essa concepção de educação.

A centralidade do conceito de formação (Bildung) para essa teorização é precedida pela remissão à filosofia da ilustração, e tem em mente um problema colocado já no debate entre Immanuel Kant e Moses Mendelssohn, em fins do século XVIII, que dizia respeito às possibilidades efetivas do ser humano ser produtor consciente da realidade e, desse modo, emancipar-se ${ }^{187}$. É a partir dessa referência que a educação (e ainda mais certamente a formação) precisa, incondicionalmente, extrapolar a sua tarefa de mera atividade socializadora. "Pois na medida em que 'formação' ['Bildung'] é algo mais e algo diferente da adaptação à sociedade existente, do estudar e do preparar-se para ela, então ela abrange não somente o tornar o ser humano apto a conhecer e entender os fatos que compõem a realidade, mas também lhe possibilita conhecer e entender aqueles fatores que põem tais fatos, de modo que ele possa transformar a sua realidade desumana"188. Adquirir consciência no que tange à produção do meio e do ser social é, assim, condição sine qua non para alterá-los. Qualquer proposta de mudança social radical que prescinda desse parâmetro está, na interpretação marcuseana, fadada ao fracasso.

particular do processo histórico, mas não transcender o processo histórico como um todo. Isso deveria ser evidente, pois não podemos pensar em qualquer coisa sob o sol que possa transcender o processo histórico como um todo. Tudo está na história, até mesmo a natureza". MARCUSE, Herbert, 1981 [1978], p. 417.

${ }^{186}$ Cf. DURKHEIM, Émile, 1973 [1903] e 1967 [1922]. O questionamento do sistema de ensino, na França, é de longa data, como aponta Christophe Charle ao referir-se às agitações de começo do século XX: "Essa experiência obriga os intelectuais, ao menos, a refletir sobre as insuficiências de um sistema educacional do qual eles são produto mas que, contrariamente ao que crêem, não realiza, em si mesmo, o progresso social por meio da meritocracia. Essa será uma das continuidades na luta dos intelectuais de esquerda franceses até os anos 1960, a luta pela 'democratização' do ensino" CHARLE, Christophe, 1996 , p. 265 - aspas no original.

187 O problema central situava-se em torno da definição do termo Aufklärung (traduzível tanto por "esclarecimento" quanto por "ilustração"), que procuravam explicar. É, portanto, a capacidade de servirse do seu próprio intelecto que torna o ser humano autônomo e é apenas desse modo que advém a emancipação: quando o raciocínio autônomo lhe possibilita a emancipação no sentido estrito do termo, de se tornar independente face a outrem, de não depender da liderança de outro. Cf. KANT, Immanuel 1975 [1784] e MENDELSSOHN, Moses, 1992 [1784]. Nesse registro a remissão explícita de Marcuse à resistência perante a sociedade estabelecida é a seguinte: "Kant declarou como fim [Ziel] da educação educar as crianças não de acordo com o estado presente, mas de acordo com um estado futuro, e melhor, do gênero humano, de acordo com a idéia de humanitas. Este fim [Ziel] ainda contém a derrubada da constituição presente do ser humano". MARCUSE, Herbert, 2004 [1966a], p. 189 - grifo no original; ver também Id., 2004 [1972], p. 34. Para mais subsídios acerca da relação entre a teoria crítica e Kant cf. MATOS, Olgária Chain Féres, 1989, pp. 279-289, em especial a nota 202.

${ }^{188}$ MARCUSE, Herbert, 2004 [1968], p. 165 - aspas no original. 
Como já referido, Marcuse perpassa, para tanto, dois eixos propostos pela teoria crítica da Escola de Frankfurt: a filiação ao marxismo, por um lado, e a 'associação' entre a teoria de Marx e a psicanálise de Freud, por outro. Um conceito de interdisciplinaridade bastante particular, substrato desse conceito de teoria crítica, visa incorporar diversas vertentes de interpretação dos seres humanos, conjugando aspectos que dizem respeito ao comportamento socialmente mediado, à distinção entre os aspectos biológicos e sociológicos presentes na 'produção' do ser humano e, no limite, desvendar até mesmo as possibilidades de uma ontologia do humano. Assim, o deslocar-se de uma teoria sistemática do social (muitas vezes rotulada de "sociologia burguesa") num sentido lato para uma crítica da sociedade incorpora um novo diagnóstico do significado da teoria de Marx, contrapondo-se a um olhar simplista, freqüentemente presente no marxismo dogmático, de uma determinação total da superestrutura pela infra-estrutura, desconsiderando a ação do indivíduo humano com um mínimo de autonomia. Assim sendo, um marco conceitual dessa formulação crítica é o fato da transformação profunda do status quo precisar estar orientada para além de uma alteração restrita somente àquela da base produtiva.

De modo a complementar essa limitação, Marcuse incorpora de modo profundo as contribuições filosóficas de Freud a uma interpretação do social. O fato de ter publicado um livro, Eros e civilização, cujo subtítulo, "Uma contribuição filosófica a Sigmund Freud", ilustra bem os propósitos do autor, é um indicativo da importância concedida à análise do indivíduo que dialoga com os postulados das necessidades da 'natureza histórica' do ser humano. O viés filosófico da psicanálise subsiste, como quando o primado da luta pela libertação tem como eixo norteador o entendimento de que é necessário atingir a 'segunda natureza', os sentidos socialmente moldados do indivíduo, que "uma tal prática compreende a quebra com o familiar, as maneiras rotineiras de ver, ouvir, sentir e entender as coisas, implicando que o organismo possa tornar-se receptivo a formas potenciais de um mundo não agressivo, não-explorador" ${ }^{\text {189 }}$. Essa abordagem implica a 'construção' de uma nova sensibilidade, que precisa encontrar fundamentos nas pulsões. Em diferentes textos são trazidos à tona termos que devem caracterizar a revolta contra essa sociedade da obsolescência planejada: a sua forma de existência, pautada pela obscenidade, provoca a repulsa como a reação imaginável perante a realidade estabelecida, e que subjaz ao conceito da grande recusa ${ }^{190}$. Ou seja, trata-se de uma nova consciência, com uma revisão da tomada de posição face aos acontecimentos do cotidiano condenáveis de um ponto de vista

\footnotetext{
${ }^{189}$ MARCUSE, Herbert, 2004 [1969], p. 246.

${ }^{190}$ Cf. MARCUSE, Herbert, 2004 [1955] e 2004 [1964a] e LOUREIRO, Isabel Maria, 1999.
} 
valorativo, já que se mostram incongruentes com o primado da razão em seu sentido libertário, concedido na emergência da modernidade.

Há raros exemplos explícitos no que se refere às formas institucionais dessa realidade inteiramente outra que deve ser construída sob o signo da nova sensibilidade. $\mathrm{O}$ mesmo não vale para as características tanto abstratas quanto concretas que devem ser encontradas no novo ser humano. "A revolta contra o capitalismo tardio tende a uma totalização das reivindicações político-econômicas, a uma profunda transvaloração dos valores: o seu fim [Ziel] seria o desenvolvimento do socialismo como a progressão do trabalho alienado para o trabalho criador; do domínio da natureza para a cooperação; da repressão para a emancipação dos sentidos; da razão exploradora para a razão solidária. A tarefa da teoria seria livrar essas possibilidades de seu véu utópico e defini-las como prática possível" ${ }^{\prime 191}$. São, portanto, tangíveis os elementos norteadores das relações sociais radical e qualitativamente transformadas que hão de possibilitar uma vida efetivamente comum, a saber, que contemple a felicidade individual mediada. Trata-se não de meramente conceituar uma totalidade ideal, mas sim de observar o concreto e o abstrato (no sentido do exercício da fantasia criativa) simultaneamente e, desse modo, ter a teoria como guia essencial para a prática.

Tal busca pelo novo ser humano expressa, de maneira mais acabada, a teoria crítica da sociedade de Marcuse: une as motivações e as balizas fornecidas pela psicanálise (com os seus elementos tanto sociais quanto biológicos), pela história, pela antropologia, pela filosofia e pela sociologia. A abordagem é, nesse sentido, total do modo preconizado por Marx: tanto disciplinarmente, ao fundir o que se quer separar numa crítica negativa abrangente, quanto teoricamente, ao abordar, em seus escritos de juventude, a conceituação de uma outra humanidade. "Dar à sensualidade e à sensibilidade seus próprios direitos é, penso eu, um dos fins básicos do socialismo integral. Essas são as características qualitativamente diferentes de uma sociedade livre. Elas pressupõem, como vocês talvez já o tenham visto, uma total transvaloração dos valores, uma nova antropologia. Elas pressupõem um tipo de ser humano que rejeita os princípios performáticos que governam as sociedades estabelecidas; um tipo de ser humano que se livrou da agressividade e da brutalidade que são inerentes à organização da sociedade estabelecida, e da moralidade puritana, hipócrita; um tipo de ser humano que é biologicamente incapaz de lutar nas guerras e criar sofrimento; um tipo de ser humano que tem uma boa consciência de alegria

${ }^{191}$ MARCUSE, Herbert, 2004 [1974b], p. 153. Para mais elementos acerca da revolução pulsional e da referência à transvaloração dos valores cf. Id., 1998 [1979]. 
e prazer e que trabalha, coletivamente e individualmente, por um ambiente natural e social no qual uma tal existência torne-se possível ${ }^{, 192}$. Uma nova antropologia traduz, assim, essa transformação radical da totalidade social: uma abordagem que não propõe (e nem poderia fazê-lo, na medida em que deseja permanecer crítica) uma separação das esferas entre o particular e o universal, mas sim que vê a totalidade social como a unidade da sociedade como ente abstrato e do humano como ente concreto, intrinsecamente ligados e figurando numa relação de interdependência inquebrantável.

Pode-se, com isso em mente, trazer à tona a discussão posta por Marcuse sobre a dialética entre materialismo e utopia (mas não idealismo!) que, a seu ver, encontra-se presente desde sempre no pensamento crítico. Nesse registro, "a idéia de um novo tipo de ser humano como parte (mesmo que não como construtor) de uma sociedade socialista aparece em Marx e Engels na concepção do 'indivíduo plurifacetado', que é livre para dedicar-se às mais variadas atividades" ${ }^{\prime 193}$. Ele reconhece o veio utópico dessa proposição, entretanto, considera o fato dela ter sido um dos propulsores dos movimentos de protesto estudantis. A clássica distinção entre o reino da necessidade e o reino da liberdade não foi elipsada, mesmo sendo classificada como utópica por muitos; pelo contrário, ela dá vazão ao exercício da fantasia, um dado estético de primeira ordem para que se possa pensar a emancipação e o salto qualitativo para um modelo de sociedade que satisfaça as necessidades humanas básicas. Seria difícil entender que uma projeção idealista fantasiosa tivesse tanto impacto sobre o movimento, mas seria incompreensível que ela provocasse a reação, a intensificação da repressão e dos mecanismos de controle da sociedade industrial

\footnotetext{
${ }^{192}$ MARCUSE, Herbert, 28 jul. 1967, p. 9. Marx, nos Manuscritos econômico-filosóficos, aventava uma definição com traços similar para o comunismo, demonstrando claramente a origem de algumas das concepções da liberdade postas por Marcuse: " $O$ comunismo como superação [Aufhebung] positiva da propriedade privada, como auto-alienação humana $e$, por isso, como a verdadeira apropriação da essência humana pelo e para o ser humano; por isso como uma volta do ser humano como social para si, isto é, como ser humano humano [menschlichen Menschen], realizada completa, consciente e internamente a toda a riqueza do desenvolvimento até agora. Esse comunismo é, como naturalismo consumado = humanismo, como humanismo consumado = naturalismo, ele é a verdadeira dissolução do conflito do ser humano com a natureza e com o próprio ser humano, a verdadeira dissolução do conflito entre existência e essência, entre objetificação e auto-confirmação, entre liberdade e necessidade, entre indivíduo e gênero". MARX, Karl, 1990 [1844], p. 536 - grifos no original.

${ }^{193}$ MARCUSE, Herbert, 2004 [1969], pp. 258 e 259 - aspas no original. Marcuse elabora as raízes do marxismo na filosofia idealista alemã em Contra-revolução e revolta. Cf. MARCUSE, Herbert, 2004 [1972], pp. 72-77). A referência a Marx e Engels aparece também no contexto do desenvolvimento da vida humana como realizado nos reinos da necessidade e da liberdade. Cf. MARCUSE, Herbert, 1969 [1967a] e 2004 [1966a], pp. 184-186. Numa conversa com Habermas, Marcuse remete diretamente à sua concepção romântica da realidade, de uma vida boa: "Qualquer um sabe que a natureza é mais bonita se eu não construo um edifício de sessenta andares à beira das margens de um lago. Para saber disso não preciso de filosofia. Isto é um apelo à estrutura pulsional. Indubitavelmente isso é mais bonito, é mais satisfatório, é mais tranqüilizador. A mesma coisa vale em relação a essas porcarias de usinas nucleares". MARCUSE, Herbert, 1991 [1977], p. 289.
} 
avançada - algo que não aconteceria, caso esses novos valores não atingissem os pressupostos básicos de seu funcionamento.

A possibilidade de quebra da hegemonia do pensamento unidimensional nessa sociedade pode, em vista disso, ser vislumbrada. As considerações quanto às categorias sensitivo-morais (obscenidade e repulsa) apresentadas por Marcuse denotam uma tomada de posição no que se refere às balizas do conceito de humanidade. Trata-se não somente da apreensão da reflexividade presente nas ações, mas sim de reconhecer o movimento dialético que permeia a coexistência da miséria e da afluência que clama pelo revolver-se dos sentidos de cada um de nós. A repulsa perante o elevado grau de exploração que rege essa sociedade deve ser fomentada como uma 'necessidade vital' do ser, de forma que ninguém mais possa ver-se face a dadas situações repressivas sem que se faça presente a vontade de enfrentá-las.

Quando nas Teses sobre Feuerbach de Marx ${ }^{194}$ a questão havia sido colocada em termos da dicotomia contemplação vs. transformação ela traduzia o momento histórico específico, sendo uma expressão legítima do materialismo histórico-dialético. Mais de cem anos depois, a impossibilidade de 'pegar nas armas' desloca a revolução para as condições subjetivas, para a 'ação sub-reptícia'. A questão de quem educa os educadores torna-se, assim, ainda mais premente. A politização, ou melhor, a contrapolitização das instituições ${ }^{195}$ que sustentam a reprodução da ordem por meio da socialização é uma condição sine qua non. Durante um ciclo de conferências realizado em Berlim em 1967 o embate é exposto com todas as letras: "Chego assim à segunda questão que pretendo discutir, isto é, ao problema das formas da oposição. Estamos falando de oposição estudantil, e eu gostaria desde logo de afirmar que não se trata de uma politização da universidade, pois a universidade já é um fato político. Basta pensar na utilização direta, no processo produtivo e na estratégia militar, das ciências naturais, inclusive de uma ciência abstrata como a matemática; basta pensar no grau de dependência financeira para com o governo e com as grandes foundations em que se encontram as ciências naturais, $e$ mesmo a sociologia e a psicologia, bem como nos serviços que essas últimas prestam aos programas de manipulação do homem e de controle do mercado. Neste sentido, podemos dizer que a universidade já é uma instituição política e que, no máximo, pode-se falar de uma sua contrapolitização e não de uma sua politização. O que importa, portanto, é elaborar uma crítica da neutralidade positivista (que não é absolutamente neutra) com

\footnotetext{
${ }^{194}$ Cf. MARX, Karl, 1969 [1845].

${ }^{195}$ Cf. MARCUSE, Herbert, 2004 [1972].
} 
referência ao programa de estudos e ao debate científico" ${ }^{\text {196 }}$. A preocupação expressa concerne fundamentalmente aos condicionantes sociais, e não materiais, da produção da pesquisa. Como se viu, a profissionalização acadêmica expandiu a pesquisa 'objetiva e neutra', que a situa acima das vontades e necessidades humanas históricas e mediadas. É justamente essa dissociação entre valor e razão que Marcuse considera inconcebível, indo ao encontro das preocupações expressas pelos movimentos de oposição que buscavam repensar a relação entre a educação e a sociedade. A perspectiva remete, assim, à "longa marcha através das instituições" de Rudi Dutschke ${ }^{197}$, que busca combater o capitalismo por dentro, tomando espaço no interior das instituições que o compõem.

Marcuse propõe, portanto, uma educação ampliada para além da adaptação individual, que promova a consciência crítica e a autonomia, na esteira do ideal de formação [Bildung]: "A educação é a nossa tarefa, mas a educação em um novo sentido. Sendo tanto teoria quanto prática, prática política, a educação, hoje, é mais do que discussão, é mais do que ensinar e aprender e escrever. A menos e até que vá além da sala de aula, a menos e até que vá além da faculdade [college], da escola, da universidade, ela permanecerá sem poder. A educação, hoje, precisa envolver a mente $\underline{e}$ o corpo, a razão e a imaginação, as necessidades intelectuais e pulsionais; pois toda a nossa existência tornouse sujeito/objeto da política, da engenharia social"198. É somente em virtude dessa abrangência que enfatizo a importância da teorização de Marcuse acerca da educação: ela constitui, necessariamente, veículo de fomento da consciência emancipada, da liberdade individual e social, pois vincula-se a todas as dimensões constituintes do ser social.

Deve-se atentar para o fato de que, por conseguinte, não se pode separar os conceitos de revolução e educação política. Trata-se de questões diferentes: a revolução é um processo que depende de diversos fatores, tanto objetivos quanto subjetivos, como, por exemplo: a conscientização; a existência de crise; o aumento da inconformidade em face da realidade posta. Numa conjuntura desse tipo, é possível que o processo revolucionário tenha início, mas nada garante que isso ocorra. Diferentemente, a educação política é uma atividade que pode e deve ser posta em prática independentemente da situação revolucionária: ela é um dos fatores capazes de mobilizar as dimensões subjetivas necessárias para a criação de um contexto pré-revolucionário ${ }^{199}$.

\footnotetext{
${ }^{196}$ MARCUSE, Herbert, 1969 [1967b], pp. 56 e 57 - grifos no original.

${ }^{197}$ Cf. MARCUSE, Herbert, 1998 [1969b] e 2004 [1970].

${ }^{198}$ MARCUSE, Herbert, 28 jul. 1967, p. 14 - grifos no original.

199 Cf. MARCUSE, Herbert, 1998 [1969b]; 1998 [1969c]; 2004 [1969]; 2004 [1972] e 1991 [1977], entre outros.
} 
Visando contemplar o questionamento referente à forma prática de colocar em ação esse trabalho de esclarecimento crítico, aponto como uma dessas modalidades de combate à esterilidade teórica localiza-se, por exemplo, num misto entre o repensar do enfoque dado à história das idéias e a responsabilidade dos intelectuais. Objetivando contrapor-se àquilo que denomino de um viés imperialista da teorização da realidade social, destaca Marcuse: “O que aparece como 'politização' externa da universidade por meio dos radicais 'desagregadores' [zersetzenden] é, hoje (como tantas vezes no passado), a dinâmica interna, 'lógica', da educação: uma tradução do conhecimento para a realidade, de valores humanísticos em condições humanas de existência. Essa dinâmica, barrada pelos traços de pseudo-neutralidade da 'Academia', poderia por exemplo ser liberada sendo incorporados à grade curricular cursos que tratem adequadamente dos grandes movimentos nãoconformistas da civilização e da análise crítica da sociedade contemporânea" ${ }^{200}$. Um ano antes, ele também havia levantado, de acordo com material que pesquisei em seu arquivo a respeito de uma palestra no Brooklyn College, que se deveria direcionar os movimentos rumo à "reorientação radical do currículo: fortalecimento das humanidades contra as ciências 'duras', incl.[usive] as ciências sociais 'duras'; ensino e pesquisa intensos de movimentos e teorias radicais, críticos na história, literatura, filosofia: - movimentos heréticos e perseguidos, - marxismo, história do socialismo, - teorias 'utópicas' (Fourier!); anarquismo, - surrealismo; e, em contraste: análise crítica do fascismo, do imperialismo" 201 . Uma questão da postura a ser tomada perante a realidade significa, nesse âmbito, uma diferença relevante quanto às representações sociais dos conceitos de obediência, tolerância e protesto tais como estavam postos. A crítica deve ser estendida a todas as esferas da atividade humana e, notadamente, da teoria; aos conceitos, à linguagem, à produção material.

Nesse registro, foram envidados amplos esforços da parte de Marcuse, como já indiquei acima em alguns trechos, para demonstrar a necessidade absoluta da teoria para a prática, questão retomada por ele em diversas palestras e também em sua obra Contrarevolução e revolta. A condição prévia da reflexão para a emancipação é, portanto, uma marca do debate: a elaboração da crítica perante os ditames do desenvolvimento capitalista proporciona a emergência da dialética presente na relação da formação (Bildung) (que deve

\footnotetext{
${ }^{200}$ MARCUSE, Herbert, 2004 [1969], p. 292 - aspas no original. Em palestra de 1967 já havia proposto demandas positivas no âmbito da educação: "extensão dos currículos para incluir o ensino de doutrinas não-conformistas e até mesmo tabus; separação dos laços entre a universidade e as agências governamentais envolvidas com o estabelecimento militar". MARCUSE, Herbert, 30 mar. 1967, p. 10.

${ }^{201}$ MARCUSE, Herbert, 1968, p. 13 - aspas e grifo no original.
} 
ser procurada também na universidade) com o ponto de vista da totalidade do funcionamento do social.

A complicada relação histórica, e que de forma alguma é resolvida por Marcuse, acerca da questão da liderança e dos liderados, é tratada com todas as letras - mantendo-se no registro da premência da formação e educação esclarecedoras. Considero que ele permanece atado a problemas insolúveis, como fica evidente no trecho a seguir, em virtude da socialização dos seres humanos necessariamente pressupor, em algum momento, um confronto de ampla desigualdade e heteronomia de uma das partes, mesmo que esse período possa, nas melhores condições, ser restrito à infância. "A libertação primária não pode ser 'espontânea', pois tal espontaneidade teria como conteúdo somente os valores e fins do sistema estabelecido. Autolibertação significa auto-educação, mas essa é precedida pela educação por parte de outros. Em uma sociedade de cuja estrutura faz parte o acesso desigual ao conhecimento $e$ à informação o antagonismo entre os educadores $e$ os educandos é inevitável. Os já formados têm a obrigação de utilizar o seu conhecimento para ajudar outros seres humanos a realizar as e gozar das suas capacidades. Toda educação real é educação política; mas em uma sociedade de classes a educação política é impensável sem uma liderança experimentada e formada pela teoria e prática da oposição radical ${ }^{, 202}$. A meu ver, ele procura aqui explicitar um problema da prática política diária e coloca, sem dubiedade alguma, a sua opinião acerca da questão: pode, sim, haver lideranças no processo constitutivo de uma frente oposicionista que consiga alterar efetivamente as condições vigentes. Esses indivíduos colocar-se-ão, em decorrência de sua revolta pessoal em face da realidade, a serviço da emancipação do todo. Esse raciocínio toma o seu lugar em decorrência da desigualdade existente em relação às possibilidades de esclarecimento colocadas à disposição da população.

Afinal, torna-se patente aqui a face do empobrecimento cultural, que se fortalece $v i s$-à-vis o relativo enriquecimento material oferecido por essa sociedade, fenômeno a que se vêem submetidos todos os seus integrantes. Nesse sentido, "tornar a universidade 'relevante' para o hoje e o amanhã requer que sejam descobertos os fatos e as energias pulsionais que fizeram da civilização [Zivilisation] o que ela é hoje e o que ela pode vir a ser no futuro - e isto é educação política. Pois a história repete-se de fato; essa repetição de dominação e submissão precisa terminar, e isso tem como condição o reconhecimento da gênese e das formas de sua reprodução: o pensamento crítico" ${ }^{203}$. Mesmo que não seja

\footnotetext{
${ }^{202}$ MARCUSE, Herbert, 2004 [1972], p. 52 - aspas no original.

${ }^{203}$ MARCUSE, Herbert, 2004 [1972], p. 61 - aspas e grifo no original. Uma referência importante quanto ao conceito negativo de razão imbricado na teoria crítica encontra-se em MATOS, Olgária Chain Féres,
} 
possível tomar as rédeas da história para guiá-la ao nosso bel-prazer, isso não nos exime de tentar levar a cabo ações e projetos que visam ultrapassar o estado de existência atual da sociedade, imbricado num conformismo passivo, em especial levando em conta a presença efetiva das condições tanto materiais quanto espirituais para ir além.

O caminho, sob o cunho da interpretação marxista, ainda reside na aquisição da consciência. O protesto não decorre do acaso, e a prática revolucionária jamais pode ser realizada sem teoria. Indivíduos cientes das condições objetivas de produção material são a base para que qualquer passo rumo à organização da revolução possa ser dado, e torna-se necessário, então, enfrentar o sistema de dominação do capitalismo organizado. " $A$ determinação social da consciência é, sob a administração e a introjeção capitalistas totais, quase que completa e imediata; elas são injetadas diretamente em cada um. Sob essas condições, o início é uma mudança radical da consciência, o primeiro passo para a transformação das condições sociais; nasce um novo sujeito. Do ponto de vista histórico, mais uma vez, o período de esclarecimento [Aufklärung] precede a transformação material - um período de educação, mas de uma educação que se converte em prática: em demonstração, confrontação e rebelião"204. É possível observar, aqui, como em seus escritos posteriores a 1964, ou seja, a partir do momento em que se vê em face de movimentos que tanto pregam quanto executam a ação a partir da elaboração teórica, Marcuse aprofunda a associação entre educação e prática política, precisando a origem do processo revolucionário como notoriamente dependente do esclarecimento.

O elemento relacionado à formação num sentido amplo, como base da autodeterminação de cada indivíduo, esteve presente nos escritos de Marcuse desde a década de 1930. Remeto à seguinte afirmação: "Quando os indivíduos socializados tiverem tomado para si a modelagem do processo de vida e tiverem tornado a totalidade das relações sociais uma obra de sua razão e de sua liberdade, então o ser-em-si dos humanos estará ligado de outra maneira à sua existência. O que antes era casual e extra-essencial passa a representar a realização das possibilidades próprias. O ser humano não poderá mais ser 'definido' como ser racional livre contra as suas condições de vida casuais, mas

1989, pp. 195-206. O conteúdo mais importante consiste, precisamente, em ser meio de elaborar os juízos acerca dos fins da ação: "A razão não é, pois, nem formal nem neutra; ela implica certos conteúdos, certas tarefas, e a razão pode julgar e denunciar certas práticas (do que a neutralização havia privado a razão). A razão não poderia pois ser relativista. Trata-se em uma certa medida de reobjetivar a Razão, de retomar algo da forma da Razão no projeto racionalista, para uma 'dialética materialista aberta', e de chegar a isso sem recair no idealismo e sem desprezar a contribuição das disciplinas científicas - cuja noção de verdade (no sentido de exatidão) não poderia ser negligenciada". Id., ibid., p. 195 - aspas no original.

${ }^{204}$ MARCUSE, Herbert, 2004 [1969], p. 285. 
sim como o criador livre e racional de suas condições de vida, como criador de sua vida melhor e mais feliz"205. Chamo a atenção, uma vez mais, para a baliza da razão como fator de apropriação da produção da vida, estando ligada à liberdade, requisito dessa autonomia ou autodeterminação ${ }^{206}$. É nesse sentido que a defesa da mudança na "segunda natureza" do ser humano, como esboçada no Ensaio sobre a libertação, consiste em moldar uma forma de racionalidade que vá de encontro à heteronomia da existência passiva e alienada.

A dificuldade que aqui se depreende está relacionada ao momento em que se deve ultrapassar a recusa em apresentar quaisquer propostas de ação, já que se torna indispensável indicar, ao menos, alguns modos de implementar as modalidades de combate intelectual delineadas, às quais fiz referência acima, com o objetivo de fomentar, nos indivíduos, o pensamento negativo que constitui o cerne da grande recusa. Assim, faz-se perceptível a contradição entre os valores da manutenção e da transformação sob a égide do principal responsável pela e regulador da educação: a sociedade, encarnada, concretamente, pelo Estado.

Nesse registro Marcuse observa a urgência em determinar um novo conceito de cultura que se oponha à perversão instrumentalizada da razão. No âmbito do ensino superior, oferece a seguinte alternativa para que se possa tentar mudar os rumos da reprodução da dominação: "Para as disciplinas acadêmicas isso significaria o deslocamento do peso para a teoria 'pura', ou seja, para a sociologia teórica, a ciência e a psicologia políticas, para a filosofia especulativa, e daí em diante. Mais importantes seriam as conseqüências para a organização da educação: o deslocamento levaria à instalação de universidades de 'elite', separadas dos colleges, que manteriam e reforçariam seu caráter de escolas profissionais no sentido amplo [...]. Já a idéia de universidades para uma elite espiritual é hoje denunciada como uma tendência anti-democrática - mesmo quando a ênfase recai sobre o 'espiritual' e o conceito de 'elite' se refere a uma escolha feita entre todos os estudantes das escolas e dos colleges, uma escolha de acordo somente com o mérito, ou seja, de acordo com a inclinação e a capacidade para o pensamento teórico. A idéia é de fato anti-democrática quando se parte do pressuposto de que a democracia de massas estabelecida e sua educação são a realização de uma democracia que corresponde, de maneira exata, às formas historicamente possíveis de liberdade e igualdade. Não creio

\footnotetext{
${ }^{205}$ MARCUSE, Herbert, 2004 [1936], p. 79 - aspas no original.

${ }^{206}$ Pode-se notar a tomada de posição em face do antigo debate, tanto na filosofia liberal quanto no socialismo, entre liberdade e igualdade. Enquanto a liberdade molda constantemente o argumento de Marcuse, a igualdade é por ele deixada de lado ou criticada no contexto da redução da individualidade decorrente da padronização das funções dos seres humanos e da inexistência da escolha qualitativa, em virtude das consequiências da massificação.
} 
que esse seja o caso" ${ }^{\text {207 }}$. A conjuntura é que determina, a seu ver, a possibilidade de recorrer a essa divisão do trabalho social. Ele não está pensando abstratamente na vida futura sob o socialismo, mas sim na concretude da existência atual e nas modalidades possíveis de alterar essa realidade. Torna-se evidente, mais uma vez, o valor concedido por Marcuse à teoria como ponto de partida da transformação radical do mundo. Essa associação decorre da premência de se mudar a consciência, o ser social, que jamais pode ser levada a cabo sem adentrar os modos de socialização.

A tarefa de extrapolar o processo de socialização do modo definido, nos primórdios da sociologia da educação, por Durkheim encontra-se, como procurei demonstrar, subjacente aos argumentos desenvolvidos por Marcuse. Enquanto a educação permanecer enredada na esfera limitada do existente, a saber, à adequação e conformarção dos indivíduos à ordem social vigente, torna-se praticamente inviável impulsionar uma mudança do pensamento para uma razão que confronte criticamente o mundo e reconheça as contradições as quais, apesar de sua evidência, são amplamente mascaradas pelo mecanismo inversor da cultura afirmativa. Em virtude disso é feita a alusão à necessidade de uma radical transvaloração dos valores, que penetre o substrato pulsional de cada indivíduo, projetando uma "segunda natureza" que prescinda dos impulsos destrutivos fomentados pela sociedade concorrencial sob a égide do princípio de desempenho.

A antevisão dessa realidade inteiramente outra esbarra em diversos obstáculos objetivos, inclusive no próprio contexto da organização da educação. Por estar a cargo do Estado, não se pode esperar, de modo algum, que haja amplas iniciativas em oferecer espaço a movimentos proponentes de uma educação que aborde conteúdos subversivos. É por conta desse diagnóstico que Marcuse reconhece: “A mudança qualitativa da educação é mudança qualitativa da sociedade, e existem perspectivas reduzidas de que uma tal mudança possa ser introduzida de maneira organizada e de modo administrativo [verwaltungsmäßig] [...]. A contradição é real: a sociedade existente precisa oferecer a possibilidade para a educação visando a uma sociedade melhor, e uma educação desse tipo pode tornar-se ameaçadora para a sociedade existente. Por isso não podemos esperar uma reivindicação comum para tal educação, nem ratificação e ajuda de cima"208. A contradição remete à questão do uso da força, visto o horizonte de expectativas que, a partir de um certo ponto, não mais torna possível proceder à crítica do estabelecido sem enfrentar uma "contra-revolução preventiva".

\footnotetext{
${ }^{207}$ MARCUSE, Herbert, 2004 [1965a], p. 127 - grifos e aspas no original. Para a referência em Eros $e$ civilização cf. MARCUSE, Herbert, 2004 [1955], p. 192.

${ }^{208}$ MARCUSE, Herbert, 2004 [1966a], p. 189.
} 
Quando enfoca a transformação de facto da totalidade, a questão da violência é explicitamente abordada por Marcuse em seus escritos. Ela já constituía um problema teórico, em virtude da proposta revolucionária preconizada por Marx em outro momento histórico, e tornou-se um problema prático no dia-a-dia da década de 1960 em decorrência da violência estatal, da violência de defesa revolucionária e da violência contrarevolucionária presentes em variadas situações e locais durante esse período. Tal tensão tem origem, primariamente, no contexto repressivo que dá origem à violência sob a égide da sociedade da afluência ${ }^{209}$. No entendimento de Marcuse, a violência pode ser um meio, mas apenas em casos extremos, em que ou as possibilidades de diálogo tenham se esgotado por completo ou os sujeitos já estejam sendo vítimas da violência física, de modo que se torna absolutamente necessário fazer uso, por sua parte, da força física para defender-se.

Em virtude do fato de as pulsões, sob o princípio de realidade vigente, provocarem a tendência ao comportamento agressivo, é realçado que, fora em casos extremos, o uso da violência deve ser evitado ao máximo. A recorrência à destruição cega configura uma forma de reprimir a energia libidinal, que é um meio fundamental de gerar uma nova relação com a natureza e os outros seres humanos. A preferência de Marcuse recai, indubitavelmente, sobre a necessidade e a premência de valorizar relações afetivas e solidárias entre os indivíduos $^{210}$. Todavia, friso que ele não é um pacifista irresoluto: para o bem ou para o mal, o uso da violência fez parte do horizonte de possibilidades. A justificativa para a decisão de recorrer à violência depreende-se de uma análise racional, no sentido forte (e, portanto, crítico) do termo, efetuada não no âmbito do puro cálculo aritmético 'objetivo', mas sim das possibilidades históricas dadas ${ }^{211}$. A violência e a repressão violenta como um

209 O problema da repressão é colocado de modo mais direto e levado às últimas conseqüências na seguinte afirmação, presente num texto que representa uma versão ampliada de uma palestra proferida em 1956: "Se a teoria de Freud está correta, que as pulsões mais destrutivas impelem à destruição da própria vida do indivíduo, sem temer o 'desvio' por outras vidas e outros fins, então podemos de fato falar de uma tendência suicida dessa sociedade, e o jogo mundial em torno da destruição total pode então ter encontrado, na estrutura pulsional dos indivíduos, uma base concreta". MARCUSE, Herbert, 2004 [1967], p. 59 - aspas no original. Ele também aborda o problema da violência sob a sociedade repressiva em 1998 [1967c].

${ }^{210}$ Veja-se os elogios que Marcuse faz, em "Marxismo e feminismo", à propagação das qualidades ditas femininas e que, para ele, são relevantes para uma sociedade livre (e, portanto, socialista), ao traduzirem a aspiração pela harmonia e pela solidariedade entre a natureza e os seres humanos assim como entre estes; cf. MARCUSE, Herbert, 2004 [1974a]; cf. também Id., 1998 [1962], 1998 [1972a], 1998 [1974], 2004 [1972], pp. 77-80 e 2004 [1975], pp. 168-170. Para referências aos sit-ins marcados por formas de protesto não-violentas que chegam, no limite, a ser incompreensíveis para uma sociedade que trabalha no registro exclusivo da recorrência à força física para solucionar os problemas, cf. Id., 1969 [1967b], pp. 57-59, 62 e 63; 2004 [1968, 1971, 1979], pp. 75 e 76 e 1998 [1968a].

211 Cf. MARCUSE, Herbert, 2004 [1964c], pp. 109-112 e 1969 [1967b], pp. 87-89. O objetivo do enfrentamento da repressão institucionalizada tem como conseqüência que "o choque com a violência, 
valor absoluto não devem ser partilhadas jamais: elas configuram um meio a ser utilizado em certas (e muito restritas e específicas) condições históricas, quando existe a possibilidade efetiva de provocar uma transformação rumo a uma sociedade qualitativamente melhor e, portanto, mais racional.

Nesse ponto, a afinidade com a crítica à violência levada a cabo por Walter Benjamin é bastante discernível, notadamente no que se refere à questão dela exclusivamente como meio e da quase que 'obrigatoriedade' da violência ser um símbolo do poder estabelecido ${ }^{212}$. O argumento de Benjamin passa pela afirmação de que o discurso diário que proclama o encerramento de uma guerra inclui, necessariamente, a justificação constante do estado pós-guerra, do status quo. Essa justificação pode ser empreendida, nesse registro, somente por meio dos acordos de paz contratualizados que detém, em seu âmago, a idéia de um período entre-guerras: tal formalismo só é benquisto por ser um ponto-de-pauta daqueles que raciocinam em termos de relações constantemente reguladas pela violência, que não conseguem projetar uma realidade para além desse limite imediatamente dado. O raro uso do termo 'paz' nos escritos de Marcuse demonstra um dos seus modos de 'filiação' a essa crítica: a existência pacificada só faz sentido quando elaborada nos termos de uma estrutura pulsional radicalmente diferente; sob as condições atuais, ela nada mais significa do que interregnos de guerra.

A admissão necessária de alguma violência passa, no pensamento marcuseano, por oscilações. Afinal, trata-se de uma afirmação demasiadamente generalizada o reconhecimento de que um processo revolucionário e, na realidade, até mesmo pré-

com a violência institucionalizada, parece ser inevitável, a não ser que a oposição se transforme num inócuo ritual destinado tão somente a pacificar as consciências, a comprovar a sobrevivência dos direitos e das liberdades no quadro da ordem constituída. [...] A oposição se encontra, portanto, em face da fatal alternativa: oposição como organização ritual, ou oposição como resistência, isto é, como civil desobedience?". Id., ibid., p. 59. Ele coloca um limite a essa forma e propõe uma clara distinção quanto ao seu emprego em grau amplo e em condições não-racionais: "não justificável, nem sequer no sentido da revolução, são os processos de Moscou, o terror permanente, os campos de concentração e a ditadura do partido sobre as classes trabalhadoras" Id., 2004 [1964c], p. 113. Quanto ao pacificismo, enfatiza que "a pregação do princípio de não-violência não faz mais do que reproduzir a violência institucionalizada da ordem existente" Id., 1969 [1967b], p. 60. Nesse ponto, Marcuse distancia-se marcadamente de Adorno e Horkheimer, que estabelecem uma relação praticamente intrínseca entre violência e barbárie, de modo a recusarem patentemente qualquer possibilidade emancipatória que recorra a esse meio; cf. MATOS, Olgária Chain Féres, 1989, pp. 273-278. Esse conflito manifestou-se de maneira aberta ao final dos anos 1960 nas cartas trocadas entre eles; cf. ADORNO, Theodor W., HORKHEIMER, Max e MARCUSE, Herbert, 1998 [1966, 1967, 1968 e 1969] assim como MARCUSE, Herbert, 1998 [1970]. Isabel Loureiro coloca a cisão sob a perspectiva de como "podemos dizer que diferentemente de Adorno e Horkheimer, que a partir dos anos 40 se dedicaram à crítica da cultura desvinculada da política radical, Marcuse levou adiante o projeto da Teoria Crítica dos anos 30 - unir filosofia, teoria social e política revolucionária". LOUREIRO, Isabel Maria, 2005, p. 10. Quanto às distinções das concepções políticas cf. ADORNO, Theodor W., 1998 [1969]; KRAUSHAAR, Wolfgang, 1998 [1989] e MARCUSE, Herbert, 1999 [1969].

${ }^{212}$ Cf. BENJAMIN, Walter, 1965 [1921] e MARCUSE, Herbert, 1965 [1964]. 
revolucionário, possa ter um caminho que perpasse esse modo de ação. A maneira de conceituar quando a realização de um ato violento é ou não 'adequada' ou 'necessária' àquela conjuntura detém um grau de abstração e arbitrariedade que marca a teoria social marcuseana, similarmente ao seu diagnóstico das necessidades falsas e verdadeiras e no esteio do que ele mesmo reconhece como uma filiação romântica de seu pensamento.

Para expô-lo com mais acuidade, passo ao argumento polêmico do ensaio Tolerância repressiva. Ali é posto, com todas as letras, o significado da tolerância sob a égide de uma sociedade repressora, e é proposta uma forma de 'intolerância', entendida como o único modo de transcender esse ambiente repressor ${ }^{213}$. A questão está formulada sob o pressuposto de que a desigualdade de forças reinante faz com que a defesa da tolerância absoluta, de uma objetividade e neutralidade empiricamente verificáveis na reserva de espaços de manifestação iguais para a esquerda e a direita e de condições similares de expor as opiniões, indubitavelmente reproduz a correlação de forças previamente dada, servindo, portanto, à manutenção das condições vigentes. Nessa linha de raciocínio, que deve estar, necessariamente, subordinada a uma análise (nas palavras de Marcuse) "racional" da situação e das possibilidades, o que se impõe é a impossibilidade de tolerar o discurso fascista e racista, que tem como mote a perpetuação de um modo de vida que conta, preponderantemente, com a exploração da força de trabalho e com o desperdício planejado, visando assim restringir o poder a uma minoria. Sob tais condições, afirma: "Mas acredito que haja, para as minorias reprimidas e controladas, um 'direito natural' à resistência em fazer uso de métodos não-legais, assim que os legais tiverem se mostrado insuficientes. Lei e ordem são sempre e em todo lugar lei e ordem daqueles que protegem a hierarquia estabelecida; é sem-sentido apelar à autoridade absoluta dessa lei e dessa ordem face àqueles que sob elas sofrem e contra elas lutam - não para uma vantagem pessoal ou por vingança pessoal, mas por quererem ser humanos. Não há outro juiz acima deles além das autoridades nomeadas, da política e da sua própria consciência. Quando fazem uso de violência não iniciam uma nova corrente de atos de violência, mas sim interrompem a estabelecida. Como neles baterão, eles conhecem o risco, e se estão dispostos a corrê-lo não há nenhum terceiro, muito menos o educador e o intelectual, com $o$ direito de pregar-lhes a abstenção" ${ }^{\text {214 }}$.

\footnotetext{
${ }^{213}$ Cf. MARCUSE, Herbert, 2004 [1965b]. Cf., ainda, Id., ibid., 1998 [1967b].

${ }^{214}$ MARCUSE, Herbert, 2004 [1965b], p. 161 - aspas no original. O reconhecimento, extremamente importante, do imperativo absoluto da oposição radical como ilegal, uma forma destacada de aproximação com a abordagem de Benjamin, é recorrente no discurso de Marcuse. Faço menção a duas passagens: "o conceito de violência se apresenta sob duas formas diversas: a da violência institucionalizada da ordem constituída e a da violência da resistência, que se destina necessariamente a
} 
O que procura matizar é o uso da violência gratuita, do que denomina de "terror", notadamente daquelas práticas que visam a matança pura e simples de pessoas, sem preocupar-se em apreender o funcionamento do sistema de dominação e, portanto, sem realmente afetá-lo. Essa discussão emergiu de modo explícito durante a década de 1970 na Alemanha, quando um grupo que se auto-intitulou RAF (Rote Armee Fraktion - Fração do Exércio Vermelho) promoveu diversos atentados contra ministros e outras pessoas que ocupavam funções-chave. Marcuse afirma: "A liquidação física de pessoas individuais, mesmo das mais proeminentes, não interrompe o funcionamento normal do próprio sistema capitalista, mas sim reforça o seu potencial repressivo - sem (e isso é o decisivo) ativar a oposição contra a repressão ou sequer levá-la à conscientização política. Certamente, essas pessoas representam o sistema: mas elas somente o representam. Isso quer dizer, elas são substituíveis, e o reservatório [Reservoir] para o seu recrutamento é quase inesgotável"215. Nesse sentido, esse tipo de ação traria mais malefícios do que benefícios aos movimentos de protesto, pois sua única função seria a de dirimir qualquer legitimidade

permanecer como ilegal em relação ao direito positivo. Falar de legalidade da resistência é um contrasenso. Nenhum sistema social, nem sequer o mais livre, pode legalizar (constitucionalmente ou de outra maneira) uma violência que vise a derrubá-lo. Portanto, cada uma dessas duas formas desempenha funções contrárias. Existe uma violência da libertação e existe uma violência da agressão. E ambas as formas de violência foram forças históricas e assim se conservarão. Desde o seu surgimento, portanto, a oposição se encontra no terreno da violência”. Id., 1969 [1967b], pp. 59 e 60. E “no que se refere à questão da violência, posso somente repetir o que já disse, que na sociedade atual a violência está institucionalizada em uma proporção monstruosa, e a questão principal é saber, em primeiro lugar, de quem parte a violência. Em todo caso creio que, no início do período de contra-revolução, pode-se dizer que a violência parte primeiramente da sociedade existente e que, deste ponto de vista, a oposição defronta-se com o problema da contraviolência, da violência de defesa, mas decerto não com a violência da agressão" MARCUSE, Herbert e POPPER, Karl, 1971, p. 20. Finalmente, ao abordar a determinação do interesse geral em contraposição ou até em superioridade face ao individual, surge uma definição do que pode ser denominado, efetivamente, de revolução: "Por revolução entendo a derrubada de um governo e de uma constituição juridicamente estabelecidos por uma classe social ou movimento cujo objetivo é transformar tanto a estrutura social quanto política. Essa definição exclui todos os golpes de estado militares, revoluções palacianas [Palastrevolutionen] e contra-revoluções 'preventivas' (como o fascismo e o nacional-socialismo), por não alterarem a estrutura social fundamental. Quando definimos a revolução dessa maneira podemos dar um passo adiante e dizer que uma mudança qualitativa tão radical abrange a violência”. MARCUSE, Herbert, 2004 [1964c], p. 101 - aspas no original.

215 MARCUSE, Herbert, 1998 [1977b], p. 807. Afirma, ainda: "O terror direciona-se primariamente contra pessoas, a violência revolucionária direciona-se contra condições”. MARCUSE, Herbert, 1998 [1978], p. 828. Marcuse avança o debate em torno da condenação do terror, notadamente do assassinato, em uma palestra cujas notas encontram-se em seu arquivo. O distanciamente absoluto dessa linguagem e desse pensamento nasce precisamente da crítica que elabora ao establishment: une-se contradições indissolúveis como a vida e a morte; a morte passa a ser vista como algo positivo no contexto da guerra permanente, e isso é algo simplesmente inadmissível. O hábito de ver-se em face de tanta crueldade, obscenidade e hipocrisia indubitavelmente imbui o espírito crítico, e adotar essa lógica para o protesto jamais poderá originar uma sociedade qualitativamente diferente. Cf. MARCUSE, Herbert, 16 fev. 1967. Para outras críticas desse mesmo problema naquele contexto cf. DUTSCHKE, Rudi, 1998 [1977]; MARCUSE, Herbert, 1998 [1972a] e NEGT, Oskar, 1998 [1972]. Para as referências e a cronologia do amplo contexto de protesto violento na Alemanha, envolvendo ações terroristas e guerrilheiras como atentados e seqüestros, e que se intensificou a partir de maio de 1970 com a criação da RAF, cf. KRAUSHAAR, Wolfgang, 1998, vol. 1, pp. 493-566. 
face à opinião pública, que os veria somente como gangues sem um objetivo mediato. Afinal, como Dutschke enfatiza, trata-se de seres humanos, e simplesmente aniquilá-los não contribui em nada para a erosão do aparelho repressor.

Retendo as idéias que envolvem a educação e a violência em Marcuse é possível passar à questão da revolução total em seu pensamento. Defendo, nesse âmbito, uma divisão entre: a revolução como um processo e a revolução como um conceito. É à revolução como um processo que entendo não ser necessária qualquer referência adicional. Compreende ela o momento efetivo da sublevação da sociedade existente, ou seja, diferencia-se das ações paulatinas, de longo-prazo, que devem ser tomadas numa situação pré-revolucionária ou, até, antes dessa, com o objetivo de, pouco a pouco, criar a consciência que reconheça a necessidade da transformação e do levante. Este é o momento que tende a estar marcado pela violência - todavia, não se trata do contexto vivido nos anos 1960 nos Estados Unidos, ponto diversas vezes frisado por Marcuse, notadamente quando questionado em entrevistas e debates se considerava que a revolução 'batia à porta'. Assim sendo, deve-se atentar para o fato de que a conscientização depende, em alto grau, da existência da revolução como um conceito histórico, no sentido dialético do termo, a saber, a presença de bases materiais e espirituais que fomentem tais ímpeto e raciocínio.

Vislumbrar o conceito de revolução significa ter para si, de forma subjetiva e mediada, uma idéia que, mesmo caso se apresente de modo negativo, não figura no reino da abstração idealista: o horizonte do olhar e do pensar deve incluir, senão a necessidade absoluta, ao menos a possibilidade da transformação. É preciso, portanto, ter um posicionamento crítico perante a realidade dada: sem essa crítica a revolução não se faz presente como conceito histórico mas, somente, como transcendental-utópico, na forma do idealismo. Essa é a realidade, imediata, para uma grande parte da população na sociedade da afluência; a satisfação proporcionada pelos bens de consumo obnubila a apreensão dos entraves estruturais que fundamentam esse modo de vida. "Com a possibilidade da revolução como 'salto qualitativo' aparece a dialética própria ao materialismo histórico o núcleo de idealismo que ele continha desde o início. A determinação da consciência pelo ser social modifica-se: com base na supressão da economia direcionada à carência e à exploração, a consciência emancipada determina o ser social, e não primariamente como inteligência funcional, como razão [Vernunft] tecno-econômica, mas como projeto [Entwurf] de possibilidades reais do ser social. Eis a utopia concreta do trabalho solidário para a satisfação da vida e do mundo da vida - uma utopia sem a qual a teoria marxista 
não pode se tornar o fio condutor de uma prática socialista" ${ }^{216}$. Observa-se aqui, portanto, um dos momentos em que transparece a idéia da conjugação de marxismo e utopia a que subjaz a distinção, tão cara a Marcuse, entre a utopia de tipo concreto e aquela de tipo idealista, fundamentada sobre a condição sine qua non enfatizada por ele desde os seus escritos da década de 1930: partir das condições materiais vigentes, históricas e concretas.

É nesse sentido que vejo, indo ao encontro do que foi proposto por Isabel Loureiro $^{217}$, uma recorrente dialética entre reforma e revolução na teoria social de Marcuse. Ela transparece tanto na biografia, minuciosamente explorada na referida palestra, quanto nos escritos, que jamais deixam de referir-se à necessidade da revolução mas, simultaneamente, incluem sempre as ressalvas quanto à existência de uma conjuntura e de amplos movimentos que realmente a possibilitem. Nisso está imbricada a especificidade da concepção de marxismo adotada, de que o conhecimento e a apreensão teórico-críticos do mundo são fundamentais para que se possa realizar a prática, mas que tal prática precisa também estar, constantemente, submetida a uma avaliação crítica de seus preceitos e de suas balizas, para evitar o perigo de advogar uma linha de ação despida de reflexão, correndo o risco de degenerar para protestos despropositados e desarticulados.

Nesse sentido, Marcuse levanta um ponto importante quanto à atuação da Nova Esquerda: o fato deles terem alterado substancialmente o conceito de revolução. Extrapolando a idéia de um mero levante violento das massas, como muitas vezes atribuída, de modo simplificador e leviano, à teoria marxista, afirma: "Transformação agora não é mais compreendida somente como mudança fundamental [Umwälzung] econômica $e$ política, ou seja, como o estabelecimento de um outro modo de produção e de novas instituições, mas também e em primeira linha como derrubada do sistema de necessidades dominante e de suas possibilidades de satisfação. Essa idéia de revolução foi desde o início um componente da teoria de Marx: o socialismo é uma sociedade qualitativamente diferente, uma sociedade em que tanto as relações entre os seres humanos quanto aquelas

\footnotetext{
${ }^{216}$ MARCUSE, Herbert, 2004 [1974b], pp. 149 e 150 - aspas no original. Ele enfatiza, no conflito acerca da problemática entre teoria e prática sob a égide do marxismo: "Parece-me que mesmo a décimaprimeira das Teses de Feuerbach já se tornou vítima da interpretação reificada - como se existisse uma seqüência histórica: primeiramente, até um determinado estágio do desenvolvimento, interpretação filosófica do mundo, e então transformação. Mas a filosofia crítica permanece elemento da transformação (como no próprio Marx), e um elemento ainda mais forte quanto mais o desenvolvimento social, visto da passagem para o socialismo, é regressivo". Id., ibid., pp. 147 e 148 - grifos no original. Para a conceituação de utopia concreta, que ele remete a Ernst Bloch, cf. MARCUSE, Herbert, 1998 [1977a], p. 798.

${ }^{217}$ Refiro-me a uma palestra, intitulada "A crítica da democracia segundo Herbert Marcuse", proferida em outubro de 2005 por ocasião da XXVIII Jornada de Ciências Humanas da Faculdade de Filosofia, Ciências e Letras da Universidade Estadual Paulista (Campus de Marília).
} 
entre o humano e a natureza são revolucionadas desde o princípio" ${ }^{\text {218 }}$. E é nesse registro de revolução do que, no capítulo primeiro do Ensaio sobre a libertação é denominado de "segunda natureza humana", que se situa o argumento fulcral: o imperativo de cada indivíduo em reconhecer, para si, os limites de sua liberdade sob a forma competitiva de existência do princípio de desempenho de gerir o conflito pulsional, que traz à tona somente os atributos agressivos e destrutivos do ser humano, impedindo-o de exercer a autonomia e de adquirir a razão.

A remissão ao fato do ser humano ter elementos biológicos, mesmo que sejam socialmente moldados durante a sua formação, é também um dado relevante para Marcuse. O ser humano não é dual, mas uno e, precisamente por conta dessa constatação, deve-se levar em conta a totalidade de sua constituição que também afeta a constituição da sociedade. "A sociedade existente não é, portanto, reproduzida unicamente no espírito, na consciência dos seres humanos, mas também em seus sentidos; e nenhuma capacidade persuasiva, teoria ou argumentação podem quebrar essa prisão enquanto a sensualidade reificada, entorpecida dos indivíduos não for 'dissolvida', não for tornada acessível a uma nova dimensão da história; enquanto a intimidade repressiva face ao mundo objetal dado não for destruída - destruída em uma segunda alienação: em relação à sociedade alienada" ${ }^{219}$. O distanciamento crítico, orientado pelo diagnóstico teórico da realidade, é o bastião da revolta, tanto individual quanto social, tanto particular quanto universal. $\mathrm{O}$ espírito humano que precisa ser criado deve ser inteiramente outro. E essa constatação levao a definir o primeiro passo da tomada de consciência como uma oposição individual e interna ao sistema de necessidades estabelecido, que passa por uma revolta das pulsões de vida, as quais chegam, por assim dizer, ao seu limite sustentável de repressão e exploração, tornando-se incapazes de submeter-se a essa situação.

Cabe sempre a ressalva: se este é o primeiro passo, ainda está longe de significar a mudança da realidade. Marcuse não se cansa de apontar os limites, considerando quase hilário quando tanto os movimentos de protesto quanto os defensores do establishment descrevem esse contexto como revolucionário: ali estava em voga somente um momento embrionário de um longo processo que ainda precisava concretizar-se. E, nesse caminho, oscila entre a simultaneidade e interdependência da revolução dos sentidos e da

\footnotetext{
${ }^{218}$ MARCUSE, Herbert, 2004 [1975], p. 159 - grifo no original. Já em O homem unidimensional esse aspecto é destacado sob esse signo na seguinte afirmação: "A auto-determinação tornar-se-á real na medida em que as massas tiverem sido dissolvidas em indivíduos, libertados de toda a propaganda, escolarização e manipulação, capazes de conhecer e compreender os fatos e de medir as alternativas. Em outras palavras, a sociedade seria racional [vernünftig] e livre na medida em que for organizada, mantida e reproduzida por um sujeito histórico essencialmente novo". Id., 2004 [1964a], p. 263.

${ }^{219}$ MARCUSE, Herbert, 2004 [1972], pp. 74 e 75.
} 
conscientização e o predomínio de uma sobre a outra, com uma tendência, como pode ser observado no trecho a seguir, em ver uma servir de guia à outra.. "Para preparar o terreno para um desenvolvimento desses carece, acima de tudo, da emancipação da consciência. Sem ela uma emancipação dos sentidos e todo ativismo radical permanecem cegos e autodestrutivos. A prática política ainda depende de teoria (somente o establishment vive sem ela): de educação, de convencimento, de razão" ${ }^{, 220}$. Isso vai ao encontro de seu elogio, ma non troppo, do espontaneísmo como figura da rebelião. Fica evidente, na erupção de formas e conteúdos de protesto espontâneos, que há um inconformismo em marcha. Entretanto, isso é pouco: restringir-se à consideração de que basta aguardar uma disseminação dessa mentalidade não levará a lugar algum; a questão da organização mantém-se premente.

E essa organização ocorre, sempre, no campo do sistema estabelecido, motivo a mais pelo qual a destruição imediata e intolerante de todos os avanços técnicos não possibilitará a emancipação. Da mesma forma, também não a trazem os ideais da vida isolada, de um "basta" exclusivamente individual aos valores e horrores desse mundo, pois a interdependência e a dialética do ser social são reais e efetivas. Desse modo, "o indivíduo burguês não é superado [überwunden] por meio da simples ignorância das exigências sociais, do tornar-se um drop-out e praticar o seu próprio estilo de vida. Evidentemente, não há revoluções sem libertação individual, mas também não há libertação individual sem a libertação da sociedade. Esta é a dialética da libertação. Tampouco é possível uma tradução imediata da teoria em prática, tampouco o é a tradução imediata das necessidades e dos desejos individuais em fins e ações políticos. A tensão entre a realidade pessoal e social ainda persiste; o solo sobre o qual aquela deve influir sobre essa ainda é a sociedade capitalista"221. Nesse contexto, a representação da teoria revolucionária como materialismo histórico-dialético ganha conteúdo e significado na interpretação marcuseana. A emancipação do indivíduo partilha da emancipação do todo; e ambos dependem francamente da análise teórico-crítica da realidade vigente. A dialética da educação é, por conseguinte, também a da revolução.

Procurei trazer uma visão que, ao tratar de educação e revolução nos termos acima, engloba a crítica que diz respeito a um tal grau de negatividade no pensamento de Marcuse que ele acabaria por passar ao largo de qualquer forma de proposta para a ação. Isso certamente é verdade no que se refere às características da sociedade futura, pós-capitalista,

${ }^{220}$ MARCUSE, Herbert, 2004 [1972], pp. 126 e 127 - grifo no original.

${ }^{221}$ MARCUSE, Herbert, 2004 [1972], p. 54 - grifos no original. 
pois considera ele que qualquer positivação de quais instituições devem compor a nova estrutura social estará imbricada nas relações pulsionais repressivas da sociedade contemporânea, regida pelo princípio de desempenho, fazendo com que, no momento atual, não seja, ainda, possível vislumbrar alternativas concretas qualitativamente diferentes. $\mathrm{O}$ mesmo não pode ser dito, como busquei enfatizar, no que se refere à organização da oposição nos dias em que ele escrevia.

A racionalidade instrumental pode ser combatida por meio da educação política, aqui abordada, cujo conteúdo transcende o pensamento unidimensional e repõe o processo dialético constituinte da história humana. Dessa forma, pode-se pensar novamente no ser social num sentido radical, o ser não apenas em si social, decorrente de sua pertença a uma sociedade, mas social para si, como agente de uma socialização solidária. Marcuse destacava como fundamentais os traços de espontaneísmo que figuravam nos movimentos de oposição. Simultaneamente, considerava que a espontaneidade por si só não seria suficiente para qualquer forma de revolução: ela requereria organização, fundada sobre uma relação completamente outra com o meio ambiente e os indivíduos. E tanto a consciência quanto a possibilidade de colocar em prática um movimento organizado têm, também, a sua raiz numa educação para a autonomia do novo ser humano.

Desse modo, fica claro que a educação como formação (Bildung) é condição prévia para a revolução total pautada pela realização dos anseios psíquico-sociais libertários. $\mathrm{O}$ diagnóstico da dominação e do controle da natureza e dos seres humanos como o valor principal a nortear a racionalidade tecnológica situa o pensamento de Marcuse em um registro que põe no centro da problemática a racionalidade cognitivo-instrumental que move o modo de produção e reprodução social da contemporaneidade, situando o seu pensamento não somente no contexto histórico em que foi produzido, mas também como referência fundamental para a análise da atualidade. 


\section{Referências bibliográficas}

ADORNO, Theodor W. "Keine Angst vor dem Elfenbeinturm". In: KRAUSHAAR, Wolfgang (Org.). Frankfurter Schule und Studentenbewegung: von der Flaschenpost zum Molotowcocktail 1946 bis 1995. Hamburg/Frankfurt am Main, Rogner \& Bernhard bei Zweitausendeins, 1998 [1969], v. 2, pp. 620-623.

ADORNO, Theodor W. e MARCUSE, Herbert. "Correspondência Marcuse-Adorno: as últimas cartas”. Trad. Isabel Maria Loureiro. Praga. Revista de Estudos Marxistas, São Paulo, n. 3, pp. 7-17, 1997 [1967-1969].

ADORNO, Theodor W., HORKHEIMER, Max e MARCUSE, Herbert. "29 cartas selecionadas". In: KRAUSHAAR, Wolfgang (Org.). Frankfurter Schule und Studentenbewegung: von der Flaschenpost zum Molotowcocktail 1946 bis 1995. Hamburg/Frankfurt am Main, Rogner \& Bernhard bei Zweitausendeins, 1998 [1966, 1967, 1968 e 1969], v. 2, pp. 218 e 219, 232 e 233, 260-263, 265, 311, 324 e 325, 487, 494,519 e $520,514,574$ e $575,577-579,601$ e 602,624 e 625,634 e 635, 639, 649655,667 e 668,671 .

ANDERSON, Perry. Considerações sobre o marxismo ocidental: nas trilhas do materialismo histórico. Trad. Isa Tavares. São Paulo, Boitempo, 2003 [1976].

BARAN, Paul A. e SWEEZY, Paul Marlor. Monopoly capital: an essay on the American economic and social order. Nova Iorque, Monthly Review, 1966.

BEHRENS, Roger. "Schillers Schönheit. Oder das Gesetz der Befreiung”. In: Polizey! Kulturzeitung zum Festival Räuber + Gendarmen, Schillerjahr 2005. Weimar, 2005. Disponível em: <www.marcuse.org/herbert/booksabout/00s/05BehrensSchiller.pdf>. Acesso em: 02 maio 2006.

BELL, Daniel. "Columbia and the New Left". In: e KRISTOL, Irving (Ed.). Confrontation - the student rebellion and the universities. Nova Iorque, Basic, 1968, pp. 67-107.

BEN-DAVID, Joseph e COLLINS, Randall. "A comparative study of academic freedom and student politics". In: LIPSET, Seymour Martin (Ed.). Student politics. Nova Iorque, Basic, 1967, pp. 148-195.

BENJAMIN, Walter. "Zur Kritik der Gewalt". In: Zur Kritik der Gewalt und andere Aufsätze. Frankfurt am Main, Suhrkamp, 1965 [1921], pp. 29-65.

BIEL, Steven. "Freedom, commitment and Marxism: the predicament of independent intellectuals in the United States, 1910-41". In: JENNINGS, Jeremy e KEMP-WELCH, Anthony (Ed.). Intellectuals in politics. Londres, Routledge, 1997, pp. 225-247.

BOKINA, John. "Morton Schoolman/Barry Katz". Telos, Nova Iorque, n. 56, pp. 213-223, 1983. 
BOVENSCHEN, Sylvia. "Die Generation der Achtundsechziger bewacht das Ereignis". In: KRAUSHAAR, Wolfgang (Org.). Frankfurter Schule und Studentenbewegung: von der Flaschenpost zum Molotowcocktail 1946 bis 1995. Hamburg/Frankfurt am Main, Rogner \& Bernhard bei Zweitausendeins, 1998 [1988], v. 3, pp. 232-238.

BRAVERMAN, Harry. Labor and monopoly capital. Nova Iorque/Londres, Monthly Review, 1974.

BROSSAT, Alain. "Violência e política". Trad. Luciano Lopreto. In: VIEIRA, Maria Alice e GARCIA, Marco Aurélio (Org.). Rebeldes e contestadores. São Paulo, Perseu Abramo, 1999, pp. 35-41.

BRUSTEIN, Robert. "The case for professionalism". In: WALLERSTEIN, Immanuel e STARR, Paul (Ed.). The university crisis reader. Nova Iorque, Random House, 1971 [1969], v. 1, pp. 546-552.

CAMPOS, Maria Teresa Cardoso de. Marcuse: realidade e utopia. São Paulo, Annablume, 2004.

CARDOSO, Irene. Para uma crítica do presente. São Paulo, 34, 2001.

CHARLE, Christophe. Les intellectuels en Europe au XIXe siècle. Paris, du Seuil, 1996.

CHARLE, Christophe e VERGER, Jacques. História das universidades. Trad. Elcio Fernandes. São Paulo, UNESP, 1996 [1994].

CHOMSKY, Noam. "Some thoughts on intellectuals and the schools". In: . American power and the new mandarins. Middlesex, Penguin, 1969 [1966], pp. 246-255.

COHEN, Arthur M. The shaping of American higher education. São Francisco, JosseyBass, 1998.

COTKIN, George. "The tragic predicament: post-war American intellectuals, acceptance and mass culture". In: JENNINGS, Jeremy e KEMP-WELCH, Anthony (Ed.). Intellectuals in politics. Londres, Routledge, 1997, pp. 248-270.

DAVIDSON, Carl. "The multiversity: crucible of the new working class". In: WALLERSTEIN, Immanuel e STARR, Paul (Ed.). The university crisis reader. Nova Iorque, Random House, 1971 [1967a], v. 1, pp. 86-99.

"Student power: a radical view". In: WALLERSTEIN, Immanuel e STARR, Paul (Ed.). The university crisis reader. Nova Iorque, Random House, 1971 [1967b], v. 1, pp. 484-487.

"Toward institutional resistance". In: WALLERSTEIN, Immanuel e STARR, Paul (Ed.). The university crisis reader. Nova Iorque, Random House, 1971 [1967c], v. 2, pp. 129-138.

DURKHEIM, Émile. Educação e sociologia. Trad. Manoel Bergström Lourenço Filho. São Paulo, Melhoramentos, 1967 [1922]. 
Moral Education. Trad. Everett K. Wilson e Herman Schnurer. Nova Iorque, The Free Press, 1973 [1903].

DUTSCHKE, Rudi. "Kritik am Terror muß klarer werden". In: KRAUSHAAR, Wolfgang (Org.). Frankfurter Schule und Studentenbewegung: von der Flaschenpost zum Molotowcocktail 1946 bis 1995. Hamburg/Frankfurt am Main, Rogner \& Bernhard bei Zweitausendeins, 1998 [1977], v. 2, pp. 805 e 806.

DUTSCHKE, Rudi e MARCUSE, Herbert. "Briefwechsel mit Rudi Dutschke" [Troca de cartas com Rudi Dutschke]. In: JANSEN, Peter-Erwin (Org.). Die Studentenbewegung und ihre Folgen - Nachgelassene Schriften. Springe, zu Klampen, 2004 [1967-1979], pp. 185-253.

ENGELS, Friedrich e MARX, Karl. "Die deutsche Ideologie ('Vorrede' und 'Feuerbach')". In: . Marx Engels Werke. Berlim, Dietz, 1969 [1845-1846], v. 3, pp. 13-77.

FULBRIGHT, J. William. "Militarism and American democracy". In: WALLERSTEIN, Immanuel e STARR, Paul (Ed.). The university crisis reader. Nova Iorque, Random House, 1971 [18 abr. 1969], v. 1, pp. 237-239.

GARCIA, Marco Aurélio. "Em busca de 1968”. In: VIEIRA, Maria Alice e (Org.). Rebeldes e contestadores. São Paulo, Perseu Abramo, 1999, pp. 7-17.

GAY, Peter. A cultura de Weimar. Trad. Laura Lúcia da Costa Braga. Rio de Janeiro, Paz e Terra, 1978 [1968].

GEIGER, Roger. To advance knowledge: the growth of American research universities 1900-1940. Nova Iorque/Oxford, Oxford University, 1986.

. "Research, graduate education, and the ecology of American universities: an interpretive history". In: ROTHBLATT, Sheldon e WITTROCK, Björn (Ed.). The European and American universities since 1800. Cambridge, Cambridge University, 1993, pp. 234-259.

GOULDNER, Alvin Ward. El futuro de los intelectuales y el ascenso de la nueva clase. Madrid, Alianza, 1985 [1979].

HABERMAS, Jürgen. "Technik und Wissenschaft als 'Ideologie'”. In: Technik und Wissenschaft als 'Ideologie'. Frankfurt am Main, Suhrkamp, 1969 [1968], pp. 48-103.

HAUG, Wolfgang Fritz. "1968 na Alemanha". Trad. Simone Mello. In: VIEIRA, Maria Alice e GARCIA, Marco Aurélio (Org.). Rebeldes e contestadores. São Paulo, Perseu Abramo, 1999, pp. 27-33.

HIRANO, Sedi. "Política e economia como formas de dominação: o trabalho intelectual em Marx". Tempo Social, São Paulo, v. 13, n. 2, pp. 1-20, nov. 2001.

HOBSBAWM, Eric. Era dos extremos. Trad. Marcos Santarrita. São Paulo, Companhia das Letras, 2000 [1994]. 
HOFSTADTER, Richard. Anti-intellectualism in American life. Nova Iorque, Alfred Knopf, 1963.

HORKHEIMER, Max. "Autorität und Familie". In:

Frankfurt am Main, Fischer, 1985 [1936], v. 3, pp. 336-417.

Gesammelte Schriften.

. "Zur Kritik der instrumentellen Vernunft". In:

Frankfurt am Main, Fischer, 1985 [1946], v. 6, pp. 23-217.

HORKHEIMER, Max e MARCUSE, Herbert. "IX - Cartas a Horkheimer". In: KELLNER Douglas (Ed.). Tecnologia, guerra e fascismo. Trad. Maria Cristina Vidal Borba. São Paulo, UNESP, 1999 [1941-1949], pp. 305-347.

HOROWITZ, Irving Louis (Org.). Poder e política. Trad. Waltensir Dutra. Rio de Janeiro, Zahar, 1965.

JACOBY, Russell. The last intellectuals: American culture in the age of academe. Nova Iorque, Basic, 2000 [1987].

JANSEN, Peter-Erwin. "O processo de habilitação de Marcuse - uma odisséia". Trad. Isabel Maria Loureiro. In: LOUREIRO, Isabel Maria (Org.). A grande recusa hoje. Petrópolis, Vozes, 1999 [s.d.], pp. 27-40.

JAY, Martin. Dialektische Phantasie. Trad. Hanne Herkommer e Bodo von Greiff. Frankfurt am Main, Fischer, 1991 [1973].

JENCKS, Christopher e RIESMAN, David. The academic revolution. Chicago, University of Chicago, 1977 [1968].

KANT, Immanuel. "Der Streit der Fakultäten”. In: . Sämtliche Werke. Leipzig, Felix Meiner, 1921 [1798], v. 5, pp. 41-166.

. "Beantwortung der Frage: Was ist Aufklärung?". In: . Sämtliche Werke. Leipzig, Felix Meiner, 1975 [1784], v. 9, pp. 133-143.

KATZ, Barry. Herbert Marcuse and the art of liberation. Londres, Verso, 1982.

KELLNER, Douglas. "Barry Katz”. Telos, Nova Iorque, n. 56, pp. 223-229, 1983. . Herbert Marcuse and the crisis of marxism. Londres, MacMillan Education, 1984.

. "Tecnologia, guerra e fascismo: Marcuse nos anos 40". In: . (Ed.). Tecnologia, guerra e fascismo. Trad. Maria Cristina Vidal Borba. São Paulo, UNESP, 1999 [1998], pp. 21-69.

KERR, Clark. Os usos da universidade. Trad. Débora Cândida Dias Soares. Fortaleza, UFCeará, 1982 [1963].

KORSCH, Karl. "Marxismo e filosofia". In: Marxismo e filosofia. Trad. António Sousa Ribeiro. Porto, Afrontamento, 1977 [1923], pp. 61-133. 
. "A situação actual do problema 'marxismo e filosofia' (também uma anticrítica)". In: Marxismo e filosofia. Trad. António Sousa Ribeiro. Porto, Afrontamento, 1977 [1930], pp. 11-59.

KRAUSHAAR, Wolfgang. "Herbert Marcuse und das lebensweltliche Apriori der Revolte". In: (Org.). Frankfurter Schule und Studentenbewegung: von der Flaschenpost zum Molotowcocktail 1946 bis 1995. Hamburg/Frankfurt am Main, Rogner \& Bernhard bei Zweitausendeins, 1998 [1989], v. 3, pp. 195-203.

(Org.). Frankfurter Schule und Studentenbewegung: von der Flaschenpost zum Molotowcocktail 1946 bis 1995. Hamburg/Frankfurt am Main, Rogner \& Bernhard bei Zweitausendeins, 1998, $3 \mathrm{v}$.

“'Die Revolte der Lebenstriebe' Marcuse als Mentor gegenkultureller Bewegungen". In: JANSEN, Peter-Erwin (Org.). Die Studentenbewegung und ihre Folgen - Nachgelassene Schriften. Springe, zu Klampen, 2004, pp. 15-25.

KRISTOL, Irving. "A different way to restructure the university". In: BELL, Daniel e . (Ed.). Confrontation - the student rebellion and the universities. Nova Iorque, Basic, 1968, pp. 145-158.

LEFORT, Claude. "Formação e autoridade: a educação humanista". In: Desafios da escrita política. Trad. Eliana de Melo Souza. São Paulo, Discurso, 1999 [1979], pp. 207-223.

LICHTMAN, Richard. "The university: mask for privilege?". In: WALLERSTEIN, Immanuel e STARR, Paul (Ed.). The university crisis reader. Nova Iorque, Random House, 1971 [jan. 1968], v. 1, pp. 101-120.

LIPSET, Seymour Martin e ALTBACH, Philip G. "Student politics and higher education in the United States". In: LIPSET, Seymour Martin (Ed.). Student politics. Nova Iorque, Basic, 1967, pp. 199-252.

LOUREIRO, Isabel Maria. "Herbert Marcuse - a relação entre teoria e prática". In: e MUSSE, Ricardo (Org.). Capítulos do marxismo ocidental. São Paulo, UNESP, 1998, pp. 99-120.

. (Org.). Herbert Marcuse: a grande recusa hoje. Petrópolis, Vozes, 1999.

. "Herbert Marcuse - anticapitalismo e emancipação". Trans/form/ação. Revista de Filosofia, São Paulo, Unesp, v. 28, n. 2, pp. 7-20, 2005.

LUKÁCS, Georg. "O que é marxismo ortodoxo?". In: História e consciência de classe. Trad. Rodnei Nascimento. São Paulo, Martins Fontes, 2003 [1919], pp. 63-104.

"Rosa Luxemburgo como marxista". In: História e consciência de classe. Trad. Rodnei Nascimento. São Paulo, Martins Fontes, 2003 [1921], pp. 105-132.

"A reificação e a consciência do proletariado". In: História e consciência de classe. Trad. Rodnei Nascimento. São Paulo, Martins Fontes, 2003 [1923a], pp. 193411. 
História e consciência de classe. Trad. Rodnei Nascimento. São Paulo, Martins Fontes, 2003 [1923b].

MACINTYRE, Alasdair. As idéias de Marcuse. Trad. Jamir Martins. São Paulo, Cultrix, 1973 [1970].

MANDEL, Ernest. "A proletarização do trabalho intelectual". In: Os estudantes, os intelectuais e a luta de classes. Trad. Serafim Ferreira. Lisboa, Antídoto, 1979 [1972], pp. 55-100.

MARCUSE, Herbert. "Prefácio". Trad. Isabel Maria Loureiro e Marcos Barbosa de Oliveira. Mimeo, [s.d.] [1957], 5 fls. Original em inglês: "Preface". In: DUNAYEVSKAYA, Raya. Marxism and freedom. Nova Iorque, Bookman Associates, 1957.

. "Nachwort" [Posfácio]. In: BENJAMIN, Walter. Zur Kritik der Gewalt und andere Aufsätze. Frankfurt am Main, Suhrkamp, 1965 [1964], pp. 97-107.

The containment of social change in industrial society [A contenção da mudança social na sociedade industrial]. Palo Alto, maio 1965, Herbert Marcuse Archiv, \# 265.00, 9 fls.

. Protest and futility [Protesto e futilidade]. Berkeley, 16 fev. 1967, Herbert Marcuse Archiv, \# 317.01, 12 fls.

. The New Left [A Nova Esquerda]. San Diego, 30 mar. 1967, Herbert Marcuse Archiv, \# 317.02, 12 fls.

. Dialectics of liberation [Dialética da libertação]. Londres, 28 jul. 1967, Herbert Marcuse Archiv, \# 316.01, 16 fls.

. Education and social change [Educação e mudança social]. Nova Iorque, 1968, Herbert Marcuse Archiv, \# 343.00, 15 fls.

. "Prefácio politico". In:

Janeiro, Zahar, 1968 [1966], pp. 13-23.

. "O fim da utopia". In: O fim da utopia. Trad. Carlos Nelson Coutinho. Rio de Janeiro, Civilização Brasileira, 1969 [1967a], pp. 11-47.

. "O problema da violência na oposição". In: O fim da utopia. Trad. Carlos Nelson Coutinho. Rio de Janeiro, Civilização Brasileira, 1969 [1967b], pp. 49-93.

. "Some social implications of modern technology" [Algumas implicações sociais da tencologia moderna]. In: Zeitschrift für Sozialforschung (Studies in Philosophy and Social Science). Munique, Deutscher Taschenbuch, 1980 [1941], v. 9, pp. 414-439.

"Teoria y política" [Teoria e política]. In: HABERMAS, Jürgen (Org.). Conversaciones con Herbert Marcuse. Trad. Gustau Muñoz. Barcelona, Gedisa, 1980 [1977], pp. 9-81. 
"On the Aesthetic Dimension: A Conversation with Herbert Marcuse". Contemporary Literature, Universidade de Wisconsin, v. 22, pp. 417-424, 1981 [1978].

. "Gespräch mit Herbert Marcuse" [Conversa com Herbert Marcuse]. In: HABERMAS, Jürgen. Philosophisch-politische Profile. Frankfurt am Main, Suhrkamp, 1991 [1977], pp. 265-319.

"Emanzipation der Frau in der repressiven Gesellschaft" [Emancipação da mulher na sociedade repressiva]. In: KRAUSHAAR, Wolfgang (Org.). Frankfurter Schule und Studentenbewegung: von der Flaschenpost zum Molotowcocktail 1946 bis 1995. Hamburg/Frankfurt am Main, Rogner \& Bernhard bei Zweitausendeins, 1998 [1962], v. 2, pp. 151-155.

"Ist die Idee der Revolution eine Mystifikation?" [É a idéia de revolução uma mistificação?]. In: KRAUSHAAR, Wolfgang (Org.). Frankfurter Schule und Studentenbewegung: von der Flaschenpost zum Molotowcocktail 1946 bis 1995. Hamburg/Frankfurt am Main, Rogner \& Bernhard bei Zweitausendeins, 1998 [1967a], v. 2, pp. 234-236.

. "Professoren als Staats-Regenten?" [Professores como regentes de Estado?]. In: KRAUSHAAR, Wolfgang (Org.). Frankfurter Schule und Studentenbewegung: von der Flaschenpost zum Molotowcocktail 1946 bis 1995. Hamburg/Frankfurt am Main, Rogner \& Bernhard bei Zweitausendeins, 1998 [1967b], v. 2, pp. 280-284.

"Nun, meine Damen und Herren: der Krieg in Vietnam..." [Entrevista concedida ao jornal televisivo Panorama]. In: KRAUSHAAR, Wolfgang (Org.). Frankfurter Schule und Studentenbewegung: von der Flaschenpost zum Molotowcocktail 1946 bis 1995. Hamburg/Frankfurt am Main, Rogner \& Bernhard bei Zweitausendeins, 1998 [1967c], v. 2, pp. 293-296.

"Der Philosoph Herbert Marcuse - Meisterdenker der Studentenrevolte" [Trechos de entrevista concedida ao jornal Le Monde]. In: KRAUSHAAR, Wolfgang (Org.). Frankfurter Schule und Studentenbewegung: von der Flaschenpost zum Molotowcocktail 1946 bis 1995. Hamburg/Frankfurt am Main, Rogner \& Bernhard bei Zweitausendeins, 1998 [1968a], v. 2, pp. 380 e 381.

"Revolutionäres Subjekt und Autonomie" [Sujeito revolucionário e autonomia]. In: KRAUSHAAR, Wolfgang (Org.). Frankfurter Schule und Studentenbewegung: von der Flaschenpost zum Molotowcocktail 1946 bis 1995. Hamburg/Frankfurt am Main, Rogner \& Bernhard bei Zweitausendeins, 1998 [1968b], v. 2, pp. 453-455.

"Welche Chancen hat die Revolution?" [Quais as chances da revolução?]. In: KRAUSHAAR, Wolfgang (Org.). Frankfurter Schule und Studentenbewegung: von der Flaschenpost zum Molotowcocktail 1946 bis 1995. Hamburg/Frankfurt am Main, Rogner \& Bernhard bei Zweitausendeins, 1998 [1968c], v. 2, pp. 488-494.

. "Zur Situation der Neuen Linken" [Quanto à situação da Nova Esquerda]. In: KRAUSHAAR, Wolfgang (Org.). Frankfurter Schule und Studentenbewegung: von der Flaschenpost zum Molotowcocktail 1946 bis 1995. Hamburg/Frankfurt am Main, Rogner \& Bernhard bei Zweitausendeins, 1998 [1968d], v. 2, pp. 496-499. 
"Der Zwang, ein freier Mensch zu sein" [A obrigação de ser um humano livre]. In: KRAUSHAAR, Wolfgang (Org.). Frankfurter Schule und Studentenbewegung: von der Flaschenpost zum Molotowcocktail 1946 bis 1995. Hamburg/Frankfurt am Main, Rogner \& Bernhard bei Zweitausendeins, 1998 [1969a], v. 2, pp. 643-648.

"Revolution aus Ekel" [A revolução pela repulsa]. In: KRAUSHAAR, Wolfgang (Org.). Frankfurter Schule und Studentenbewegung: von der Flaschenpost zum Molotowcocktail 1946 bis 1995. Hamburg/Frankfurt am Main, Rogner \& Bernhard bei Zweitausendeins, 1998 [1969b], v. 2, pp. 655-660.

"Nicht einfach zerstören - Über die Strategie der Linken" [Não basta destruir sobre a estratégia da esquerda]. In: KRAUSHAAR, Wolfgang (Org.). Frankfurter Schule und Studentenbewegung: von der Flaschenpost zum Molotowcocktail 1946 bis 1995. Hamburg/Frankfurt am Main, Rogner \& Bernhard bei Zweitausendeins, 1998 [1969c], v. 2, pp. 668 a 670.

"Ich habe nie behauptet, daß der Kapitalismus krisenfest ist" [Eu nunca afirmei que o capitalismo fosse à prova de crises]. In: KRAUSHAAR, Wolfgang (Org.). Frankfurter Schule und Studentenbewegung: von der Flaschenpost zum Molotowcocktail 1946 bis 1995. Hamburg/Frankfurt am Main, Rogner \& Bernhard bei Zweitausendeins, 1998 [1970], v. 2, pp. 720 e 721.

. "Dieser Terror ist konterrevolutionär" [Esse terror é contra-revolucionário]. In: KRAUSHAAR, Wolfgang (Org.). Frankfurter Schule und Studentenbewegung: von der Flaschenpost zum Molotowcocktail 1946 bis 1995. Hamburg/Frankfurt am Main, Rogner \& Bernhard bei Zweitausendeins, 1998 [1972a], v. 2, pp. 758 e 759.

"Die Verlegenheit des revolutionären Geistes" [O embaraço do espírito revolucionário]. In: KRAUSHAAR, Wolfgang (Org.). Frankfurter Schule und Studentenbewegung: von der Flaschenpost zum Molotowcocktail 1946 bis 1995. Hamburg/Frankfurt am Main, Rogner \& Bernhard bei Zweitausendeins, 1998 [1972b], v. 2, pp. 759-761.

. "Zu 'Marxismus und Feminismus" [Entrevista a respeito de "marxismo e feminismo']. In: KRAUSHAAR, Wolfgang (Org.). Frankfurter Schule und Studentenbewegung: von der Flaschenpost zum Molotowcocktail 1946 bis 1995. Hamburg/Frankfurt am Main, Rogner \& Bernhard bei Zweitausendeins, 1998 [1974], v. 2, pp. 784-787.

. "Ökologie und Gesellschaftskritik" [Ecologia e crítica social]. In: KRAUSHAAR, Wolfgang (Org.). Frankfurter Schule und Studentenbewegung: von der Flaschenpost zum Molotowcocktail 1946 bis 1995. Hamburg/Frankfurt am Main, Rogner \& Bernhard bei Zweitausendeins, 1998 [1977a], v. 2, pp. 796-801.

"Mord darf keine Waffe der Politik sein" [O assassinato não pode ser uma arma da política]. In: KRAUSHAAR, Wolfgang (Org.). Frankfurter Schule und Studentenbewegung: von der Flaschenpost zum Molotowcocktail 1946 bis 1995. Hamburg/Frankfurt am Main, Rogner \& Bernhard bei Zweitausendeins, 1998 [1977b], v. 2 , pp. 806 e 807. 
"Ich habe niemals Terror gepredigt" [Jamais preguei o terror]. In: KRAUSHAAR, Wolfgang (Org.). Frankfurter Schule und Studentenbewegung: von der Flaschenpost zum Molotowcocktail 1946 bis 1995. Hamburg/Frankfurt am Main, Rogner \& Bernhard bei Zweitausendeins, 1998 [1978], v. 2, pp. 828-831.

"Die Revolte der Lebensbetriebe" [A revolta das pulsões de vida]. In: KRAUSHAAR, Wolfgang (Org.). Frankfurter Schule und Studentenbewegung: von der Flaschenpost zum Molotowcocktail 1946 bis 1995. Hamburg/Frankfurt am Main, Rogner \& Bernhard bei Zweitausendeins, 1998, v. 2, pp. 834-836

. Reason and revolution [Razão e revolução]. Nova Iorque, Prometheus/Humanity, 1999 [1941].

" A nova mentalidade alemã". In: KELLNER, Douglas (Ed.). Tecnologia, guerra e fascismo. Trad. Maria Cristina Vidal Borba. São Paulo, UNESP, 1999 [1942], pp. 193255.

. "Descrição de três projetos importantes". In: KELLNER, Douglas (Ed.). Tecnologia, guerra e fascismo. Trad. Maria Cristina Vidal Borba. São Paulo, UNESP, 1999 [1946/1947], pp. 257-266.

"33 teses". In: KELLNER, Douglas (Ed.). Tecnologia, guerra e fascismo. Trad. Maria Cristina Vidal Borba. São Paulo, UNESP, 1999 [1947], pp. 289-303.

"Perspectivas do socialismo na sociedade industrial avançada - uma contribuição ao debate". Trad. Isabel Maria Loureiro. In: LOUREIRO, Isabel Maria (Org.). A grande recusa hoje. Petrópolis, Vozes, 1999 [1965], pp. 47-55.

. "Herbert Marcuse fala aos estudantes". Trad. Robespierre de Oliveira. In: LOUREIRO, Isabel Maria (Org.). A grande recusa hoje. Petrópolis, Vozes, 1999 [1968], pp. 57-70.

. "Reflexões sobre Theodor Adorno". Trad. Isabel Maria Loureiro. In: LOUREIRO, Isabel (Org.). A grande recusa hoje. Petrópolis, Vozes, 1999 [1969], pp. 103-107.

. "Pela frente única das esquerdas". Trad. Isabel Maria Loureiro. In: LOUREIRO, Isabel Maria (Org.). A grande recusa hoje. Petrópolis, Vozes, 1999 [1972], pp. 109-123.

. "Herbert Marcuse - vida e obra". Trad. Isabel Maria Loureiro. In: LOUREIRO, Isabel Maria (Org.). A grande recusa hoje. Petrópolis, Vozes, 1999 [1978], pp. 11-25.

. "A sociedade como obra de arte". Trad. Ricardo Corrêa Barbosa. Novos Estudos, São Paulo, n. 60, pp. 45-52, jul. 2001 [1967].

. "A noção de progresso à luz da psicanálise". Trad. Isabel Maria Loureiro. In:

Cultura e psicanálise. São Paulo, Paz e Terra, 2001 [1968], pp. 112-139.

"Der deutsche Künstlerroman" [O romance-de-artista alemão]. In: Schriften.

Springe, zu Klampen, 2004 [1922], v. 1, pp. 7-344. 
"Beiträge zu einer Phänomenologie des Historischen Materialismus" [Contribuições a uma fenomenologia do materialismo histórico]. In: Klampen, 2004 [1928], v. 1, pp. 347-384. Schriften. Springe, zu . "Zum Problem der Dialektik I" [O problema da dialética I]. In: Schriften. Springe, zu Klampen, 2004 [1930a], v. 1, pp. 407-422.

"Transzendentaler Marxismus" [Marxismo transcendental]. In: Schriften. Springe, zu Klampen, 2004 [1930b], v. 1, pp. 445-468.

. "Zum Problem der geschichtlichen Wirklichkeit" [Sobre o problema da verdade histórica]. In: . Schriften. Springe, zu Klampen, 2004 [1931], v. 1, pp. 469-487.

"Neue Quellen zur Grundlegung des Historischen Materialismus" [Novas fontes para a fundamentação do materialismo histórico]. In: . Schriften. Springe, zu Klampen, 2004 [1932], v. 1, pp. 509-555.

"Zum Begriff des Wesens" [Para o conceito de essência]. In: . Schriften. Springe, zu Klampen, 2004 [1936], v. 3, pp. 45-84.

"Philosophie und kritische Theorie" [Filosofia e teoria crítica]. In: . Schriften. Springe, zu Klampen, 2004 [1937a], v. 3, pp. 227-240.

. "Über den affirmativen Charakter der Kultur" [Sobre o caráter afirmativo da cultura]. In: . Schriften. Springe, zu Klampen, 2004 [1937b], v. 3, pp. 186-226.

. "Zur Kritik des Hedonismus" [Para a crítica do hedonismo]. In: . Schriften. Springe, zu Klampen, 2004 [1938], v. 3, pp. 250-285.

. Triebstruktur und Gesellschaft - Schriften [Eros e civilização]. Trad. Alfred Schmidt. Springe, zu Klampen, 2004 [1955], v. 5.

- Die Gesellschaftslehre des sowjetischen Marxismus - Schriften [Marxismo soviético]. Trad. Alfred Schmidt. Springe, zu Klampen, 2004 [1958], v. 6.

. Der Eindimensionale Mensch - Schriften [A ideologia da sociedade industrial avançada]. Trad. Alfred Schmidt. Springe, zu Klampen, 2004 [1964a], v. 7.

. "Industrialisierung und Kapitalismus im Werk Max Webers" [Industrialização e capitalismo na obra de Max Weber]. In: Schriften. Springe, zu Klampen, 2004 [1964b], v. 8, pp. 79-99.

"Ethik und Revolution" [Ética e revolução]. Trad. Alfred Schmidt. In: Schriften. Springe, zu Klampen, 2004 [1964c], v. 8, pp. 100-114.

"Bemerkungen zu einer Neubestimmung der Kultur" [Comentários a uma redefinição da cultura]. Trad. Alfred Schmidt. In: . Schriften. Springe, zu Klampen, 2004 [1965a], v. 8, pp. 115-135.

"Repressive Toleranz" [Tolerância repressiva]. Trad. Alfred Schmidt. In: Schriften. Springe, zu Klampen, 2004 [1965b], v. 8, pp. 136-161. 
"Das Individuum in der Great Society" [O indivíduo na Great Society]. Trad. Alfred Schmidt. In: Schriften. Springe, zu Klampen, 2004 [1966a], v. 8, pp. 167-193.

. "Zum Begriff der Negation in der Dialektik" [Sobre o conceito de negação na dialética]. In: . Schriften. Springe, zu Klampen, 2004 [1966b], v. 8, pp. 194-199.

"Aggressivität in der gegenwärtigen Industriegesellschaft" [Agressividade na sociedade industrial contemporânea]. In: [1967], v. 8, pp. 41-59. . Schriften. Springe, zu Klampen, 2004

. "Nachtrag zu Repressive Toleranz" [Posfácio à Tolerância repressiva]. Trad. Horst Brühmann. In: . Schriften. Springe, zu Klampen, 2004 [1968], v. 8, pp. 162-166.

. Versuch über die Befreiung [Ensaio sobre a libertação]. Trad. Helmut Reinicke e Alfred Schmidt. In: 317. . Schriften. Springe, zu Klampen, 2004 [1969], v. 8, pp. 237-

. USA: Organisationsfrage und revolutionäres Subjekt [EUA: a questão da organização e o sujeito revolucionário]. In: 2004 [1970], v. 9, pp. 171-189. Schriften. Springe, zu Klampen,

Konterrevolution und Revolte [Contra-revolução e revolta]. Trad. Renate e Rolf Wiggershaus. In: . Schriften. Springe, zu Klampen, 2004 [1972], v. 9, pp. 7-128.

. "Marxismus und Feminismus" [Marxismo e feminismo]. Trad. Walle Bengs e Uli Laukat. In: . Schriften. Springe, zu Klampen, 2004 [1974a], v. 9, pp. 131-142.

. "Theorie und Praxis" [Teoria e prática]. In: Schriften. Springe, zu Klampen, 2004 [1974b], v. 9, pp. 143-158.

. "Scheitern der Neuen Linken?" [Fracasso da Nova Esquerda?]. Trad. Hans-Martin Lohmann. In: . Schriften. Springe, zu Klampen, 2004 [1975], v. 9, pp. 159-170.

"Die Permanenz der Kunst: Wider eine bestimmte marxistische Ästhetik" [A Dimensão Estética]. In: Schriften. Springe, zu Klampen, 2004 [1977], v. 9, pp. 191-241.

"1968 und die Studentenbewegung" [1968 e o movimento estudantil]. In: JANSEN, Peter-Erwin (Org.). Die Studentenbewegung und ihre Folgen - Nachgelassene Schriften. Springe, zu Klampen, 2004 [1968, 1971, 1979], pp. 83-139.

MARCUSE, Herbert e NEUMANN, Franz. "Uma história da doutrina da mudança social" e "Teorias da mudança social" In: KELLNER, Douglas (Org.). Tecnologia, guerra e fascismo. Trad. Maria Cristina Vidal Borba. São Paulo, UNESP, 1999 [s. d.], pp. 137150 e pp. 151-191.

MARCUSE, Herbert e POPPER, Karl. Revolution oder Reform? Marcuse vs. Popper. Munique, Kösel, 1971. 
MARX, Karl. Grundrisse der Kritik der Politischen Ökonomie. Berlim, Dietz, 1953 [18571858].

. "Thesen über Feuerbach". In: . e ENGELS, Friedrich. Marx Engels Werke. Berlim, Dietz, 1969 [1845], v. 3, pp. 5-7.

. "Der achtzehnte Brumaire des Louis Bonaparte". In: e ENGELS, Friedrich. Marx Engels Werke. Berlim, Dietz, 1960 [1852], v. 8, pp. 111-207.

. "Vorwort zur Kritik der Politischen Ökonomie". In: . e ENGELS, Friedrich Marx Engels Werke. Berlim, Dietz, 1961 [1859], v. 13, pp. 3-11.

Das Kapital (v. 1) - Marx Engels Werke. Berlim, Dietz, 1968 [1867], v. 23.

. "Ökonomisch-philosophische Manuskripte". In: . e ENGELS, Friedrich. Marx Engels Werke. Berlim, Dietz, 1990 [1844], v. 40, pp. 465-588.

MATOS, Olgária Chain Féres. Os arcanos do inteiramente outro: a Escola de Frankfurt, a melancolia e a revolução. São Paulo, Brasiliense, 1989.

. “Tardes de maio". Tempo Social, São Paulo, v. 10, n. 2, pp. 13-24, 1998.

MENDELSSOHN, Moses. "Sobre a pergunta: o que quer dizer ilustrar?". Trad. Maria Lucia Mello e Oliveira Cacciola. Discurso, São Paulo, Dep. de Filosofia da Universidade de São Paulo, v. 19, pp. 59-65, 1992.

MILLS, Charles Wright. A nova classe média: white collar. Trad. Vera Borda. Rio de Janeiro, Zahar, 1951.

. The sociological imagination. Nova Iorque, Oxford University, 1959.

. "A estrutura do poder na sociedade americana". In: HOROWITZ, Irving Louis (Org.). Poder e política. Trad. Waltensir Dutra. Rio de Janeiro, Zahar, 1965 [1958], pp. $25-42$

. "A nova esquerda". In: HOROWITZ, Irving Louis (Org.). Poder e política. Trad. Waltensir Dutra. Rio de Janeiro, Zahar, 1965 [1960], pp. 123-136.

MINOGUE, Kenneth. O conceito de universidade. Trad. Jorge Eira Garcia Vieira. Brasília, Unb, 1981 [1977].

MUSSE, Ricardo. "Teoria e prática". In: LOUREIRO, Isabel Maria e (Org.).

Capítulos do marxismo ocidental. São Paulo, UNESP, 1998, pp. 13-33.

NEGT, Oskar. "Sozialistische Politik und Terrorismus". In: KRAUSHAAR, Wolfgang (Org.). Frankfurter Schule und Studentenbewegung: von der Flaschenpost zum Molotowcocktail 1946 bis 1995. Hamburg/Frankfurt am Main, Rogner \& Bernhard bei Zweitausendeins, 1998 [1972], v. 2, pp. 752-757. 
NIETZSCHE, Friedrich. “Über die Zukunft unserer Bildungsanstalten”. In: COLLI, Giorgio e MONTINARI Mazzino (Org.). Friedrich Nietzsche: Sämtliche Werke (Kritische Studienausgabe). Munique, Deutscher Taschenbuch, 1988 [1972], v. 1, pp. 641-752.

NISBET, Robert Alexander. The degradation of the academic dogma. New Brunswick, Transaction, 1997 [1971].

OLIVEIRA, Robespierre de. O papel da filosofia na teoria crítica de Herbert Marcuse. São Paulo, 2001, Tese de doutoramento (filosofia). Faculdade de Filosofia, Letras e Ciências Humanas da Universidade de São Paulo.

PARSONS, Talcott. "The academic system: a sociologist's view". In: BELL, Daniel e KRISTOL, Irving (Ed.). Confrontation - the student rebellion and the universities. Nova Iorque, Basic, 1968, pp. 159-183.

RINGER, Fritz K. O declínio dos mandarins alemães. Trad. Dinah de Abreu Azevedo. São Paulo, Edusp, 2000 [1968].

ROCKWELL, Paul. "The Columbia Statement". In: WALLERSTEIN, Immanuel e STARR, Paul (Ed.). The university crisis reader. Nova Iorque, Random House, 1971 [12 set. 1968], v. 1, pp. 23-47.

ROTHBLATT, Sheldon. "The limbs of Osiris: liberal education in the English-speaking world". In: . e WITTROCK, Björn (Ed.). The European and American universities since 1800. Cambridge, Cambridge University, 1993, pp. 19-73.

SAID, Edward Wadie. Representations of the intellectual. Nova Iorque, Vintage, 1996 [1993].

SCHILLER, Friedrich von. "Über die ästhetische Erziehung des Menschen". In:

Schiller Werke. Salzburgo, Das Bergland-Buch, 1951 [1793-1794], v. 1, pp. 527-590.

SHILS, Edward. O apelo da educação. Bauru, EDUSC, 2001 [1997].

SWEEZY, Paul Marlor. "Marx and the proletariat". In: Modern capitalism and other essays. Londres/Nova Iorque, Monthly Review, 1972 [1967], pp. 147-165.

. "Socio-cultural transformation in developing countries". In: . Modern capitalism and other essays. Londres/Nova Iorque, Monthly Review, 1972 [1969], pp. $15-24$.

THERBORN, Göran. "Dialética da modernidade: a teoria crítica e o legado do marxismo do século XX”. Trad. Luis Fernandes. Dados, v. 38, n. 2, Rio de Janeiro, IUPERJ, pp. 237$275,1995$.

TORSTENDAHL, Rolf. "The transformation of professional education in the nineteenth century". In: ROTHBLATT, Sheldon e WITTROCK, Björn (Ed.). The European and American universities since 1800. Cambridge, Cambridge University, 1993, pp. 109141. 
TOURAINE, Alain. The academic system in American society. New Brunswick, Transaction, 1997 [1974].

TROW, Martin. "Comparative perspectives on British and American higher education". In: ROTHBLATT, Sheldon e WITTROCK, Björn (Ed.). The European and American universities since 1800. Cambridge, Cambridge University, 1993, pp. 280-299.

VALLE, Maria Ribeiro do. A violência revolucionária em Hannah Arendt e Herbert Marcuse. São Paulo, UNESP, 2005.

VERGER, Jacques. As universidades na Idade Média. Trad. F. M. L. Moretto. São Paulo, UNESP, 1990 [1973].

WALD, George. "A generation in search of a future". In: WALLERSTEIN, Immanuel e STARR, Paul (Ed.). The university crisis reader. Nova Iorque, Random House, 1971 [4 mar. 1969], v. 1, pp. 4-12.

WALLERSTEIN, Immanuel e STARR, Paul (Ed.). The university crisis reader. Nova Iorque, Random House, 1971, 2 v.

WEBER, Max. "Wissenschaft als Beruf". In: Max Weber Gesamtausgabe Abteilung I. Tübingen, J.C.B. Mohr (Paul Siebeck), 1992 [1917], v. 17, pp. 70-111.

WIGGERSHAUS, Rolf. The Frankfurt school. Trad. Michael Robertson. Cambridge, MIT, 1994 [1986].

WITTROCK, Björn. "The modern university: the three transformations". In: ROTHBLATT, Sheldon e __. (Ed.). The European and American universities since 1800. Cambridge, Cambridge University, 1993, pp. 303-362.

WOLFF, Robert Paul. O ideal da universidade. Trad. Sonia Veasey Rodrigues e Maria Cecilia Pires Barbosa Lima. São Paulo, UNESP, 1991 [1969].

ZINN, Howard. "Dow shalt not kill". In: WALLERSTEIN, Immanuel e STARR, Paul (Eds.). The university crisis reader. Nova Iorque, Random House, 1971 [1967], v. 1, pp. 248-255. 


\section{Textos de Herbert Marcuse}

Quais as chances da revolução?

\section{A revolução pela repulsa}

EUA: a questão da organização e o sujeito revolucionário

A revolta das pulsões de vida

Somente no formato digital, a segunda parte da dissertação, contendo as quatro traduções, encontra-se retida conforme solicitação do autor, por motivo de patente, publicação ou direito autoral. 